\title{
An evaluation of labour market forecasts by type of education and occupation for 2002
}

Citation for published version (APA):

Dupuy, A. (2005). An evaluation of labour market forecasts by type of education and occupation for 2002. Researchcentrum voor Onderwijs en Arbeidsmarkt, Faculteit der Economische Wetenschappen. ROA Working Papers No. 1E https://doi.org/10.26481/umarow.200501E

Document status and date:

Published: 01/01/2005

DOI:

10.26481/umarow.200501E

Document Version:

Publisher's PDF, also known as Version of record

\section{Please check the document version of this publication:}

- A submitted manuscript is the version of the article upon submission and before peer-review. There can be important differences between the submitted version and the official published version of record. People interested in the research are advised to contact the author for the final version of the publication, or visit the DOI to the publisher's website.

- The final author version and the galley proof are versions of the publication after peer review.

- The final published version features the final layout of the paper including the volume, issue and page numbers.

Link to publication

\footnotetext{
General rights rights.

- You may freely distribute the URL identifying the publication in the public portal. please follow below link for the End User Agreement:

www.umlib.nl/taverne-license

Take down policy

If you believe that this document breaches copyright please contact us at:

repository@maastrichtuniversity.nl

providing details and we will investigate your claim.
}

Copyright and moral rights for the publications made accessible in the public portal are retained by the authors and/or other copyright owners and it is a condition of accessing publications that users recognise and abide by the legal requirements associated with these

- Users may download and print one copy of any publication from the public portal for the purpose of private study or research.

- You may not further distribute the material or use it for any profit-making activity or commercial gain

If the publication is distributed under the terms of Article $25 \mathrm{fa}$ of the Dutch Copyright Act, indicated by the "Taverne" license above, 


\title{
An evaluation of labour market forecasts by type of education and occupation for 2002
}

\author{
ROA-W-2005/1E \\ Arnaud Dupuy
}

Research Centre for Education and the Labour Market

Faculty of Economics and Business Administration Maastricht University

Maastricht, April 2005 
ISBN 90-5321-408-9

Sec05.044 


\title{
An evaluation of labour market forecasts by type of education and occupation for 2002
}

\author{
Arnaud Dupuy
}

April 26, 2005

\section{Contents}

1 Introduction $\quad 3$

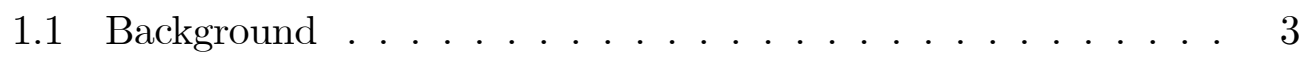

1.2 Motivation for the evaluation . . . . . . . . . . . . 4

1.3 Goal and structure of the forecast . . . . . . . . . . 6

1.4 Structure of the report . . . . . . . . . . . . . . . 12

2 Methodology for the empirical evaluation 13

2.1 Introduction . . . . . . . . . . . . . . . . . . . 13

2.2 An evaluation criterion . . . . . . . . . . . . . . . . 14

2.3 The causes of forecasting errors . . . . . . . . . . . . 17

2.4 The evaluation of qualitative characterizations . . . . . . 20

3 Expansion demand $\quad 22$

3.1 Introduction . . . . . . . . . . . . . . . . . . 22

3.2 Expansion demand forecast . . . . . . . . . . . . . . 22

3.3 Empirical evaluation of expansion demand forecast . . . . . . 27

3.4 Conclusion . . . . . . . . . . . . . . . . . 33

4 Replacement demand $\quad 33$

4.1 Introduction . . . . . . . . . . . . . . . . . . . . 33

4.2 Forecasting method . . . . . . . . . . . . . . . . 34

4.3 Empirical evaluation of replacement demand forecast by occupational class . . . . . . . . . . . . . . 36 
4.4 Empirical evaluation of replacement demand forecast by educational type . . . . . . . . . . . . . . 39

4.5 Conclusion . . . . . . . . . . . . . . . . . . 42

5 Job Openings 43

5.1 Introduction . . . . . . . . . . . . . . . . 43

5.2 Forecasting method . . . . . . . . . . . . . . . 43

5.3 Empirical evaluation of job openings forecast . . . . . . . . . . 44

5.4 Conclusion . . . . . . . . . . . . . . . . . 47

$\begin{array}{llr}6 & \text { Supply } & 47\end{array}$

6.1 Introduction . . . . . . . . . . . . . . . 47

6.2 Forecasting method . . . . . . . . . . . . . . . . . . 48

6.3 Empirical evaluation of supply by type of education . . . . . . 50

6.4 Conclusion . . . . . . . . . . . . . . . . . 52

7 Confrontation of demand and supply $\quad 52$

7.1 Introduction . . . . . . . . . . . . . . . 52

7.2 Labour market indicator . . . . . . . . . . . . . . . . 53

7.3 Evaluation of the future labour market perspectives . . . . . . 54

7.4 Conclusion . . . . . . . . . . . . . . . . . 62

8 Conclusion $\quad 62$

9 Nederlandse samenvatting $\quad 66$

$\begin{array}{ll}10 \text { References } & 68\end{array}$

$\begin{array}{ll}\text { Appendix } & 72\end{array}$ 


\section{Introduction}

\subsection{Background}

The Research Centre for Education and the Labour Market generates every two years medium-term forecast of the labour market prospects of types of education and occupations. The first forecast were generated in 1989, after a pilot in 1987, under a contract from the Ministry of Education and Science. The project intended in first instance to cover the development of an information system of use especially for providing educational and vocational guidance to apprentices and students in secondary and higher education. Gained experience has shown that the information provided by ROA's forecast was also of primary interest for other labour market agents, namely policy makers and employers.

The labour market information provided by ROA's forecast are used various information products at the national level, for instance by the National Career Guidance Information Centre (LDC) and the Centre for Information on Higher Education for Consumer and Expert (CHOICE). The first forecast were used to supplement the labour market module I see!. This was a computerised information system, established by LDC, bringing together information from many sources which might be relevant for the choice of a career or course of study. Vocational guidance by teachers and others involved in assisting students to make these choices could call up this information via their personal computer and obtain, along with other information on study and vocational choices, an idea of the labour market consequences of the choices which were available. The LDC brought out another information system, 'Traject', which also makes use of labour market information provided by ROA. ROA's forecast have also been one of the foundations of the LDC's series of brochures for study and vocational guidance, and both the 'Keuzegids Hoger Onderwijs' and the 'Studiekeuze-Informatiedatabase' published by CHOICE. In addition in their own database, the Central for Work and Income (CWI) used the current data and the forecast of the information system to formulate policies on employment in general and vocational guidance for the unemployed in particular.

As part of this process, the first pilot research project was completed in 1987. This covered current labour market information and forecast for university education (De Grip, Heijke and Vos, 1987, De Grip et al., 1987a, 1987b and 1988). In 1989 the first forecast for the full width of the education 
system were compiled (De Grip et al., 1989 and De Grip, Heijke and Dekker, 1989), covering developments in the period up to and including 1992 for 79 occupational classes and 53 types of education. The forecast by occupational classes encompassed predictions of the expansion demand and replacement demand, which together comprise the 'job openings'. The forecast for the various types of education also included predictions of the expected supply, so that a confrontation of demand and supply could be made, on the basis of which a characterisation could be given of the expected future labour market situation. The forecast were supplemented with current data and a number of indicators as regards the occupational classes and types of education which had been differentiated.

Since the first forecast in 1989, the ROA has generated 7 waves of forecast, in 1990/91 and from 1993 on every two years. The latest forecast have been generated in 2003 concern the period running to 2008. The information system has undergone strong modifications and developments since 1989. For instance, the models used to generate forecast have been modified in order to adapt to more and more disaggregated educational and occupational classifications and provide more disaggregated information. The models have also benefited from the results of previous evaluation studies. The first forecast were evaluated in de Grip, Heijke and Berendsen (1991), and Borghans, van Eijs and de Grip (1994). The 1994 forecast were evaluated in Borghans, van Eijs and Smits (1996), the 1998 forecast in Smits and Diephuis (2001) and the 2000 forecast in Cörvers, et al. (2004). This report evaluates the 2002 forecast and will follow the same structure as the previous evaluation studies. Besides the empirical evaluation, this report provides an overview of the methodology in used the various parts of the model at the time the forecast were generated (see Borghans et al., 1997). In addition, this report provides an objective analysis of the strong and weak points of each part of the model and indicates in which direction future developments should aim. When possible, the quality of the 2002 forecast will be compared with the quality of the previous forecast.

\subsection{Motivation for the evaluation}

Although the focus of attention, when compiling an evaluation of forecast, is mainly on the period in which the forecast was created and the period to which they related, an evaluation is also very important in relation to future forecasting activities. 
For the users of forecast of the future labour market, differentiated by education and occupation, it is useful to have some information about the reliability of the forecast. Borghans (1993) has shown that publicly accessible predictions, as aids in choosing a course of study, have a positive influence on students' choices and therefore on the working of the labour market, provided that students have a reasonable idea of the usefulness of these forecast. Two things are important in this respect: the first is that the students have a clear concept of the rationale underlying the forecast. The total picture provided by a forecast should be broken down according to the factors from which it is composed, so that the basis on which particular developments are expected is clear. This makes it possible to compare the forecast with the students' own expectations of future labour market developments and/or various other sources of information. The second requirement is that students have an idea of the average accuracy of the predictions, because this in part determines the degree to which they have to take the forecast of the information system into account. It is therefore important to check which points the forecast is reasonably accurate on, and where the uncertainties lie. It is also important to know how the degree of uncertainty is expressed in the way in which the forecast are published.

A good evaluation of past forecast is also very important for those compiling forecast. When compiling forecast a choice must be made between the many possible ways of modelling the labour market. This choice is based on a certain understanding of the functioning of the market. If it was only the quality of the data which determined the quality of the forecast, the only lesson which could be derived from an evaluation would be a call for more or better data. But an evaluation of the forecast can also provide new understandings of the applicability of the methods used. This is especially so for forecast within an information system that is still in the development phase: a fundamental evaluation can also reveal the strong and weak points of the method.

Those who commission forecast are another group with an interest in the evaluation of the predictions. On one hand this evaluation can provide information as to the priorities which should guide the further development of the information system. On the other hand it is important for those commissioning forecast to know how useful the forecast are for their target group.

New classifications of education and occupation were introduced in 1997 to generate forecast by educational types and occupational groups to 2002 . 
These new classifications might have had significant impact on the forecast to 2002. Therefore throughout the analysis of the forecast to 2002 we will pay particular attention to the extent to which these classification changes have contributed to the forecasting errors. Note that since 1997, both classifications have remained in use.

In 1997, ROA chose to implement a new occupational classification that is closely related to the 3-digits "Standaard Beroepenclassificatie" 1992 (SBC'92). ROA had significantly contributed to the construction of the SBC'92 classification of Statistics Netherlands. This choice led to an increase from 93 to 127 occupational groups. ROA's classification is different of SBC'92 classification in two aspects. First, in collaboration with Statistics Netherlands, the elementary occupations have been further disaggregated in the ROA classification. Second, ROA renamed - in collaboration with LDC - the job titles to help users to identify occupations more rapidly and easily.

The new educational classification is the result of a research aiming at developing an educational classification that would rely on labour market economic criteria. ${ }^{1}$ In this classification, educational types are clustered based on the extent to which their respective occupational domains overlap. The number of educational types increased from 83 to 113 and the decomposition of educational types reflects more closely the labour market reality than the previous classification.

On the one hand, the increase in the number of categories distinguished in both the educational and occupational classification may be expected to lead to lower forecasting quality On the other hand, however, this might lead to an improvement of the forecasting quality since categories are now more homogeneous than in the previous classifications.

Two other minor changes have been implemented in the forecast to 2002 . Firstly, a more comprehensive data set has been used to forecast the inflow of school-leavers into the labour market. Secondly, an indicator for the future recruitment problems of employers (IFRP) has been introduced to broaden the use of the forecast. The indicator will be evaluated in this report.

\subsection{Goal and structure of the forecast}

Any evaluation of forecast made within the framework of ROA's information system must rely on an assessment of the extent to which these forecast

\footnotetext{
${ }^{1}$ See Heijke et al. (2003).
} 
accomplish the purposes for which they were compiled. It is therefore important to have a clear picture of the overall forecast structure and of the objectives of the forecast at the time they were made. This makes it possible to look at both the accuracy of the forecast and at how far the structure which was employed was suited to the goals which had been set.

Purposes of the forecast

The 1989 report formulated the primary and secondary goals of the Information System for Education and the Labour Market. "The ROA Information System for Education and the Labour Market has, at least for now, the primary goal of generating information which can be useful in choosing a course of study or an occupation. However this information system could in principle also be useful for capacity planning in the education system, and policies relating to the labour supply, the economic structure and technology, as well as the personnel policy of both the government and businesses." (De Grip, Heijke and Dekker, 1989, p. 1).

Because the second objective is presented here only as an option, and is moreover very general, this evaluation will be related specifically to the first of these objectives. This means that the forecast and the forecast structure will be examined throughout in terms of their usefulness for those choosing a course of study or an occupation.

The objective of generating information which can be useful in choosing a course of study and for vocational guidance has two implications for this evaluation. First of all, the structure of the information system needs to be suitable, so that the data which are generated can assist in the educational or vocational decisions of an individual student. i.e., the information must:

1. be relevant for the students;

2. be relevant at an individual level;

3. be presented in such a way that students can interpret it properly.

The first requirement, relevance for students, means that the forecast should relate to factors which can be important in making educational or vocational choices. That is, the forecast must provide understanding of the labour market situation which a student will encounter from the moment of entering the market after the completion of studies. This requirement thus 
determines the period to which the forecast must refer - the period in which students will have just left school — and the group in the labour market for which they must be relevant - the school-leavers.

The second requirement relates to significance at an individual level. Since the goal is to assist in educational and vocational decision-making, the forecast must be usable in making an individual choice regarding a particular type of education or occupation. For the student facing the choice of a course of study, it is relevant to know what situation he may face in the labour market at the end of his education. Some developments may be very relevant, in a general sense, for a description of the labour market, but only usable for an individual if they are translated to the individual level. For instance, the total growth in employment for a particular educational category is interesting for those making policy decisions, but for a student it is more important to know what his or her individual chance of getting a particular sort of work at the end of the course may be.

The third requirement for the structure of the forecast system, if it is to be usable for educational and vocational guidance, is that the information must be presented in an interpretable form. If they are to be usable for students, the forecast must for expressed in terms which are comprehensible for someone who is not entirely adept in labour market interpretations. The forecast results should, as far as possible, be expressed in generally understood concepts with a minimum of statistical or economic jargon. A translation is especially important for statistical judgments regarding the reliability of the forecast. Improvements in the ease of interpretation of the labour market data can however come in two ways: it may also be sensible to improve students' understanding of the functioning of the labour market so as to improve the comprehensibility of labour market information.

A second consequence of the objective of generating information which is useful for study and occupational choices is that the empirical evaluation will also be made from this standpoint. This means that the evaluation criterion which is used in determining the magnitude of forecasting errors must in the first place show what consequences these forecasting errors have had for individual occupational and vocational choices. The selection of a criterion for the evaluation is discussed in section 2.2.

Structure of the forecast

Figure 1.1 gives a schematic overview of the structure of the forecasting 
method. On the demand side, the forecast of employment in economic sectors which are obtained from the Central Planning Bureau (CPB) provide an external source of information. These forecast are based on the so-called Athena model of CPB (see CPB 1993). At that time, these forecast covered 22 economic sectors. The predicted numbers employed in these economic sectors are then translated into the employment in 127 occupational classes. This predicted level of demand for occupations, when compared with the situation in 1985, yields the expected expansion demand for each occupational class. This is supplemented with a forecast of the expected replacement demand. Together, the expansion and replacement demand comprise the expected number of job openings. It is assumed that it is the number of job openings which is the relevant quantity for educational and vocational decisions. New entrants to the labour market cannot in practice simply crowd the people already working out of their jobs. On the basis of a breakdown of past flows into the labour market, a calculation is also made of how many of these job openings are available for school-leavers.

The expansion demand for each occupation is translated, by means of a distribution model, into the expansion demand per type of education. The replacement demand for the various types of education is calculated separately, because this cannot be derived from the replacement demand per occupation. Together, the replacement and expansion demand make up the total demand for new entrants with a particular educational background.

In addition to the forecast of demand, a forecast is made for each type of education of the expected supply of school-leavers entering the labour market between 1997 and 2002. These forecast are based on the forecast outflow of school-leavers from the educational system (Referentieramming) generated by the Ministry of Education, Culture and Science and supplemented with additional data on part-time education and courses outside the regular, government-supervised education system (i.e. 'non-regular' education). The total supply of new entrants together with the short-term unemployed at the beginning of the forecasting period determine the total supply. The assumption is that only short term unemployed workers at the beginning of the forecasting period compete with school-leavers. Based on the forecast of supply and demand, we calculate the 'indicator of the future labour market' (IFLM). This indicator gives an information about the tensions between demand and supply in the labour market in the period under consideration. Because the model which has been used takes no account of possible adjustments in the labour market in response to these tensions between demand 


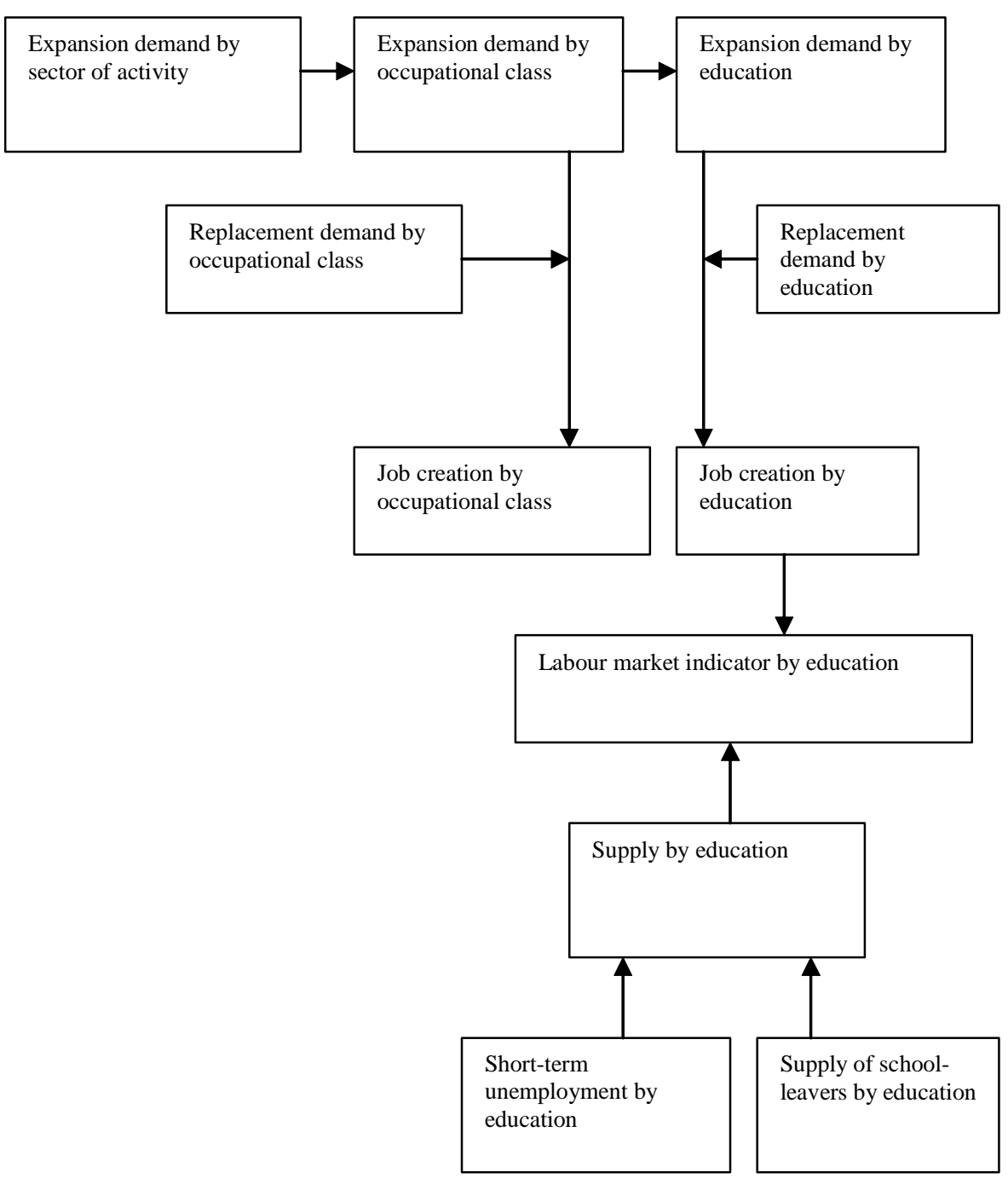

Figure 1: Structure of the forecasting model of the Information System on Education and the Labour Market 
and supply, this indicator of tension must not simply be regarded as the expected over-supply or shortage. Naturally both the demand and supply sides of the labour market will to some extent adjust in response to these tensions, so that, for example, an over-supply of new entrants with a particular education will not necessarily be expressed in high unemployment, but could also lead to stagnating wages, an increased probability of having to find work outside of the intended field of employment, or other deteriorations in the labour market situation (see Wieling and Borghans (2001)).

In addition to these forecast of the number of job openings per occupational class, the information system also contains current data and indicators for each occupational class. The current data cover among other the number of workers in a particular occupational class, a breakdown into the component occupational groups, the age distribution of the workers, a breakdown by educational categories and types of education, economic sectors and sub-sectors, and the proportion of self-employed workers, plus the trends in these figures. The underlying idea is that such information can contribute to widening the horizons for those receiving educational and vocational guidance and in various ways give some understanding of a number of relevant characteristics of the labour market for a particular occupational class.

The indicators relate to the inflow of workers who are under 30 years old, the dispersion of the occupations among the various economic sectors and the sensitivity of employment to the state of the business cycle. The assimilation rate shows how many young people work in an occupation, as compared with other occupations. The dispersion over economic sectors and sensitivity to cyclical forces are both 'risk indicators'. The dispersion indicator shows how widely the employment for workers in this occupational class is spread over various economic sectors. If there is a wide dispersion, any unexpected change in a particular economic sector will have relatively little influence on the developments in that occupation. Wide dispersion would also indicate that, if demand in one of the economic sub-sectors should decline, there would probably be possibilities of work in other economic sectors. The sensitivity to cyclical forces shows the extent to which employment for the occupation rises and falls with the fluctuations in the business cycle. High cyclical sensitivity means, in the first place, an increased chance that the labour market prospects may deteriorate at some time later in a worker's career. It also indicates that there is a greater likelihood that the forecast will not be realized.

For educational types, the following data are presented (among other): 
employment level, percentage of female, and the percentage of workers overeducated for their job. Moreover, an indication is given of the dispersion of employment across occupations and economic sectors. Like the indicators for occupations, these dispersion indicators give an impression of the robustness of the forecast, but also show in a more general way the extent to which the choice of a particular type of education will leave students dependent on the labour market situation for a particular occupational class or a particular economic sector.

For educational and vocational guidance purposes, the quantitative data of the forecast, current data and indicators are all transformed into qualitative characterizations. On the basis of the values which have been established for the variables, a classification is made in each case on a five-point scale, on which the ranges are characterized as 'very low', 'low', 'average', 'high' or 'very high'. The intention of these qualitative characterizations is to render the quantitative figures of the forecast, indicators and current data more accessible for people who are not accustomed to dealing with such figures. In the first place they do not have to understand the measurement units in which the variables are measured. In the second place, this method gives an immediate relative characterisation, so that it is not necessary to examine the dispersion of the variable. In the third place, the division into five intervals produces a characterisation which gives a less exact impression than the figures themselves, avoiding the suggestion of accuracy to the last decimal point, and giving a certain bandwidth to the labour market forecast in particular.

\subsection{Structure of the report}

The report proceeds as follows: chapter 2 discusses the methodology used for the evaluation of the forecast. In each following chapters, 3, 4, 5, 6 and 7 , we begin by discussing the methodology used to generate the forecast of expansion demand (in chapter 3), replacement demand (in chapter 4), job opening (in chapter 5), supply in chapter (6) and the future labour market indicator in chapter 7 . In the second part of each of these chapters we present the evaluation results of the respective forecast. Chapter 8 concludes. 


\section{Methodology for the empirical evaluation}

\subsection{Introduction}

The previous chapter discussed the structure of the information system. The forecast made at that time for the components of this system will be subject, so far as possible, to an empirical evaluation in the following chapter. To give a systematic character to this empirical evaluation, this chapter first describes an evaluation method, beginning in section 3.2 with the problems encountered in the empirical evaluation.

In the light of the central importance of the selection of a model, Granger and Newbold (1986) also argue for a fundamental evaluation as a means of improving the forecasting methodology. They reason that an evaluation should be carried out at two levels: the subjective and the objective. At the subjective level, the forecast and the actual events are carefully compared and the factors which might have caused the forecasting errors are ascertained, focusing especially on extremely large forecasting errors. It is also possible to determine whether there were incidental causes for the appearance of such exceptional results. One has to ask whether an incidental factor should have been foreseen at the time the forecast was compiled.

One risk of this subjective method, however, is that the evaluation can degenerate into an accumulation of incidents. Where such incidents occur repeatedly, there may be structural shortcomings in the forecasting method which was used. Therefore Granger and Newbold consider the second phase, the objective evaluation, to be even more important. They set out three questions which any objective evaluation should answer (Granger and Newbold, 1986, pp. 277):

1. are the forecast better than the available alternatives?

2. how 'good' are the forecast?

3. can the method with which the forecast were compiled be adapted in such a way that an improvement in forecasting quality would be expected?

Then, on the basis of the objective of the information system, a criterion is introduced against which the system can be evaluated (section 3.3). This criterion makes it possible primarily to evaluate the loss which arises through 
forecasting errors. To get a better idea of the causes of the forecasting errors, a number of tests are discussed in section 3.4. Finally, section 3.5 deals with the evaluation of the qualitative characterizations.

\subsection{An evaluation criterion}

There is often not much point in considering every forecast separately, because many forecasting errors are quite accidental. It is difficult to derive any lessons from these. Therefore it is better to examine the pattern in the forecasting errors.

This raises the question of how the forecasting errors should be aggregated. A criterion needs to be found by which the separate forecasting errors can be weighted, so that they can be reduced to one measure. This section will discuss the choice of this evaluation criterion and how this measure will be used in this evaluation. In addition to finding a suitable way of combining the separate forecasting errors, judgement must be passed on the quality of the forecast.

As has been said above, the basic principle in assessing the forecast of the Information System on Education and the Labour Market is the purpose of the forecast, that they must be suitable for educational and vocational guidance. Most predictions are formulated in terms of people who are working. For an individual student, however, it is not the total number of working people in an occupation or with a given education, or the absolute difference in these numbers, which is interesting. It is mainly a question of the relative difference: $\frac{\left(x_{i}-\widehat{x}_{i}\right)}{y_{i}}$ in which $x_{i}$ represents the outcome for some quantity relating to occupation or education $\mathrm{i}$, and $\widehat{x}_{i}$ represents the forecast for the same quantity. $y_{i}$ indicates employment in persons in occupation or education category i. ${ }^{2}$ Assuming that this relative measure is normally distributed, it is meaningful to interpret the square of the relative variation as the loss for each forecast (Granger and Newbold, 1986, pp. 277).

$$
L_{i}\left(\widehat{x}_{i}\right)=\left(\frac{x_{i}-\widehat{x}_{i}}{y_{i}}\right)^{2}
$$

where $L_{i}()$ is the individual loss for category $i$.

Because ROA's information system includes forecast for 127 occupational

\footnotetext{
${ }^{2}$ By definition, $x_{i}=y_{i}$ for the expansion demand .
} 
classes and 113 types of education, ${ }^{3}$ it is certainly possible and, in view of the quantity of information desirable, to aggregate separate forecasting errors. This aggregation makes it possible to appraise the probability distribution of the forecasting errors, rather than evaluating every prediction on its own. The loss shows how great the 'damage' resulting from a particular forecasting error is, so that it is possible to calculate the average loss and thus to aggregate the forecasting errors. In aggregating this criterion, it must be remembered that many more students find places in a large occupational group or a large educational category than in a small one. The average loss $(A L)$ is determined by weighting the separate losses according to the size of the occupational or educational category. This is the evaluation criterion at the aggregated level:

$$
A L(\widehat{x})=\sum_{i} \frac{y_{i}}{y^{t o t}} L_{i}\left(\widehat{x}_{i}\right)=\frac{1}{y^{t o t}} \sum_{i} \frac{\left(x_{i}-\widehat{x}_{i}\right)^{2}}{y_{i}}
$$

where $y^{\text {tot }}=\sum_{i} y_{i}$ is the actual total number of workers and $A L$ is the average loss.

The individual loss criterion thus gives an approximation of the loss which is relevant for the choice of an individual student considering a particular occupation or educational course, and the average loss indicates the loss of an average student. The evaluation criteria described above are applicable to the evaluation of forecast of employment levels. Only a subgroup of the total employment is included in the forecast of the replacement demand and the job openings. In that case the numerator in the loss function remains the total number of people working, so that the forecasting error remains related to the size of the occupational class or the type of education. These total figures are also used as weights in determining the average loss.

The loss function in equation 2 is a widely-used criterion, and has also been applied in this context by Bosworth, Evans and Lindley (1974), Evans and Lindley (1973), Borghans and Heijke (1996) and Van Eijs and Borghans (1997), among others, for the evaluation of manpower forecasting methods. The criterion gives an estimate of the distribution of the predictions around the outcome, and so meets the second requirement which Granger and Newbold (1986) propose for an objective evaluation. However this figure does not

\footnotetext{
${ }^{3}$ The forecast are published for only 104 types of education. The remaining 9 educational types are considered as non-homogenous.
} 
permit any judgement to made as to the quality of the forecast. In fact there is no information available as to what a reasonable value for the average loss would be. Such a standard of judgement can be created by comparing the forecast with the predictive quality of other forecast available at that time, in accordance with the first requirement proposed by Granger and Newbold. A score is defined as the ratio between the predictive quality of the forecast and the predictive quality of a reference forecast. This score is smaller than 1 if the forecast is better than the reference forecast and is more than 1 if the forecast is inferior to the reference:

$$
S\left(\widehat{x}, x^{r e f}\right)=\frac{A L(\widehat{x})}{A L\left(x^{r e f}\right)}
$$

To fill out this definition in practice, a particular forecast must be designated as the reference forecast. In this report the principle is that the forecast should be compared with the situation which would have faced students if no forecast from the information system had been available to them. The assumption is that students would then have based their choice on the current labour market situation. Therefore the situation in the base year is used as a reference forecast. This Same As Before (SAB) forecast supposes that there will be no changes between the base year and the forecast year. But in some cases, such as in relation to the replacement demand, the Same As Before forecast is not meaningful as a reference point. It is not really plausible to suppose that students know how high the replacement demand is at that moment. In this case it is more plausible to take the average predicted replacement demand as a percentage of the number of working people as a reference forecast for the replacement demand per occupation or type of education.

A last point to be considered is the scale on which the forecast should be evaluated. When making educational and vocational choices, it is mainly important to get a good estimate of the relative position of an occupation or type of education, and the absolute magnitude of a particular figure is not of prime importance. Therefore the evaluation in this report is generally performed on both the absolute forecast and also on a forecast which has been corrected for the total volume effects, i.e. the forecast are multiplied by a factor such that the total magnitude of all the occupations (or types of education) is equal to the actual outcome. These forecast have been called 
the relative forecast.

\subsection{The causes of forecasting errors}

The average loss and the score, which were discussed in the previous section, provide information on the quality of the predictions. They do not in themselves show why a forecast has proved to be good or bad, so that it is not clear how the forecasting method could be modified on the basis of the evaluation results. But this is, according to Granger and Newbold (1986), the third important point in making an objective evaluation. To enable conclusions to be drawn on the basis of this evaluation which explain the nature of the problems which can be expected in the forecast, and to be able to describe the consequences of the methodology which was used, the evaluation yardstick will be supplemented with a number of tests to provide information as to the causes of the forecasting errors.

\section{Concentration of forecasting errors}

The evaluation yardstick described in the previous section shows the average forecasting error for all occupations or all types of education. To understand the causes of these forecasting errors it will be necessary to examine the forecasting error in particular economic sectors, occupational classes or types of education. There are three possible ways of grouping forecast for such an approach. One might examine the quality of the forecast for each type of education or for each occupation, separately. One disadvantage of this approach is that the element of chance in forecasting errors will not be shown up. Every forecasting error is seen as a unique incident, so that the structure behind the forecasting errors is lost sight of. The usefulness of this information for an objective evaluation is not great, but, using Granger and Newbold's (1986) approach, an overview of all the separate forecasting errors can be useful for a subjective evaluation. For this reason, tables showing errors for each occupation and type of education are included in this report, although only the individual loss has been calculated and not the score, because the score is extremely sensitive to the quality of the reference forecast: if chance factors produce a good reference forecast in a particular case, the score of the ROA forecast is likely to be bad.

A second way of grouping the occupations or types of education is on the basis of the classification criteria themselves, i.e., on the basis of the 
nature of the economic sector, the occupational class or the type of education. For example, in evaluating the forecast for types of education it would be interesting to know whether the forecasting errors are different for each educational level.

A third method is to group forecast according to the methodologies used for particular occupational classes or types of education. In several cases, a different forecasting method was used for some occupations or types of education. It is very interesting to see whether there are differences in the quality of the forecast produced with these methods. Of course it must be borne in mind that there will have been reasons for the choice of a particular forecasting method. There were grounds for following one methodology for a particular occupation or type of education and a different methodology for another occupation or type of education. Thus there may be an element of selectivity, which could produce a bias in the evaluations of each methodology.

\section{Explaining the forecasting errors}

The difference between the forecast and the actual outcome can best be treated as the outcome of a stochastic variable. At the moment that the forecast is made it is - at least so far as the forecaster is concerned - not possible to predict how large the forecasting errors will be. For evaluation purposes it is interesting to get some idea of the distribution of this random variable: an estimate will be made in the empirical evaluation in chapter 4 , based on the premise that the forecasting errors are normally distributed with an expectation of 0 . Thus the only parameter which is not known is the standard deviation of this distribution. To give some insight into the nature of the forecasting errors, this standard deviation is estimated as a function of a number of explanatory variables:

$$
\varepsilon_{i}=x_{i}-\widehat{x}_{i} \sim N\left(\mu_{i}, \sigma_{i}^{2}\right)
$$

with

$$
\begin{aligned}
\sigma_{i} & =y_{i}^{\alpha} e^{Z_{i} \beta} \\
\mu_{i} & =\theta\left(\widehat{x}_{i}-x_{i}^{r e f}\right)
\end{aligned}
$$


where $x_{i}$ is again the amount of the quantity for which the prediction was made (for example occupational class or type of education) and $Z_{i}$ are explanatory variables for the standard deviation $\sigma_{i}$ of the forecast.

The first factor in equation 5, the size of the occupation or the educational category, is included to determine the effect of scale. Larger forecasting errors would be expected for larger occupational classes or types of education, but the increase in these forecasting errors will probably be less than proportional. $\alpha$ is expected to lie between 0 and 1 . The choice of the other explanatory variables for the size of the standard deviation of the forecasting errors depended on the quantity being considered. These explanatory variables can be grouped in categories similar to the classification above, i.e., into variables related to the nature of the quantity covered by the forecast, and variables connected with the methodology used.

As noted above, the Information System on Education and the Labour Market also contains 'risk indicators'. These indicators are partly intended to give an idea of the sensitivity of a particular occupational class or a type of education to exogenous influences. A relation would be expected between these risk indicators and the magnitude of the forecasting error. The method based on equations 4 and 5 can also be used to indirectly evaluate these risk indicators.

The form of equation 5 was selected to ensure that the standard error is always positive. Equations 4 and 5 are estimated using the maximum likelihood method.

\section{Overestimation or underestimation of changes}

One important component in most forecast is the trend in the quantity which is to be predicted. In extrapolating existing trends it is crucial to establish how this extrapolation should be effected. Simply extending trends often leads to improbable results, especially in the longer term. In that case the trend is only partially incorporated in the forecast, or an approach is chosen which reduces the influence of the trend over time. In principle, similar problems emerge with every explanatory variable. If a parameter estimate happens to be high, the influence of this variable will continue to be overestimated. Therefore, a parameter for which the estimate was not significant when compiling the forecast is often ignored.

An evaluation is a suitable way to examine the extent to which the estimated influences of the exogenous variables in the past have been properly 
extended into the future. An extrapolation which was too cautious will appear as an under-estimation of change, while an exaggerated extrapolation will over-estimate the change (see Theil, 1958, pp. 68 and Borghans, 1993, chapter 10). By estimating equation 6 it is fairly simple to test for the over or underestimation of changes. Figure 2 shows how to interpret the value of the over-under estimation coefficient $\theta .{ }^{4}$ Three areas are marked out in the figure by two limiting values. If $\theta=0$ then the actual figures are, on average, equal to the forecast. The quality of the forecast may nevertheless be bad, but there is no systematic overestimation or underestimation of the changes. $\theta>0$ means that the actual figures were, on average, further away from the value in the base year than the forecast, so the changes have been underestimated. If $-1<\theta<0$ then the actual figures for the predicted quantity lie, on average, closer from the value in the base year than the forecast, so that the changes have been overestimated. If $\theta<-1$ then the overestimation of changes is total, so that none of the predicted changes had any informative value, and one might equally well have taken either the reference forecast or the ROA forecast. If $\theta$ is smaller than -1 , there has been an inversion effect. This means that, where falls were predicted there has, on average, been a rise, while quantities for which rises were predicted have, on average, fallen.

An overestimation of changes need not necessarily have been caused by over-extrapolating trends. Often it results from a large random element in the forecast. If forecast contain some noise in addition to their informative qualities, it may be sensible to partly ignore the predicted changes. The larger this random element is, the more cautiously the forecast should be treated. In (6) this would be expressed by a value of $\theta$ close to -1 .

\subsection{The evaluation of qualitative characterizations}

The evaluation method which has been outlined above has thus far referred only to the point forecast produced by the forecasting models in the information system. But as has been said, the forecast are ultimately presented by means of a qualitative characterisation of the forecast results.

The most direct way of evaluating these qualitative characterizations is by assigning qualitative characterizations to the actual outcomes, using the same classification system, and then to examine how often this corresponds to

\footnotetext{
${ }^{4}$ It is assumed that the forecast is higher than the value of the variable in the base year, although the reverse is also possible. The situation then would be the mirror image of the situation shown in Figure 2.
} 


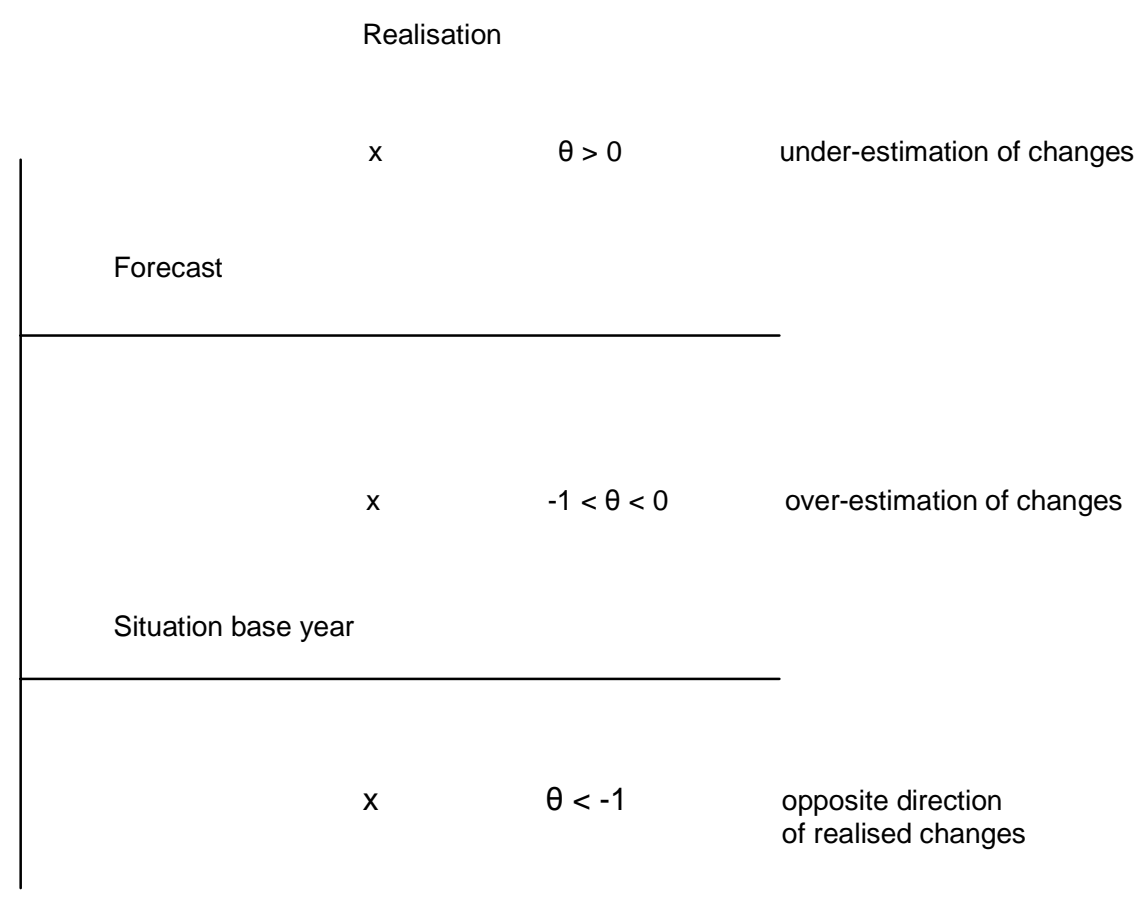

Figure 2: Possible values of the underestimation coefficient $\theta$ for overestimation and underestimation of changes. 
the original characterisation (see also De Grip, Heijke and Berendsen, 1991). Such an evaluation is made on the basis of a matrix, with the original characterisation and the outcome on the two axis. ${ }^{5}$ The forecast quality and the method of characterisation are then in fact being evaluated simultaneously. Previous evaluation reports have shown that qualitative evaluation with large intervals could be misleading and indicate that good quality forecast are bad and vice versa, quality evaluation with small intervals could indicate that bad forecast are rather good.

\section{Expansion demand}

\subsection{Introduction}

The first component of the demand forecast in the information system concerns the expansion demand. Since the expansion demand varies substantially between occupational and educational categories, forecasting expansion demand is relatively harder than forecasting the other components of the information system. Furthermore, most employment time series available by education and occupation are rather short, i.e. 10 years, which restricts the range of possible analyses and upper bounds the degrees of freedom in the estimation of expansion demand. In this chapter, we first present in section 3.2 the methodology used to generate the forecast in the period 1997-2002. Thereafter we present the results of the evaluation of these forecast.

\subsection{Expansion demand forecast}

Figure 3.1 indicates how the forecast of expansion demand by occupation and education are derived. The expansion demand forecast are based on the CPB forecast of employment by sector of industry for the period 1997-2002. CPB used the Athena model for forecasting employment by sector of activity (see CPB (1993)). In a first step, the employment forecast by sector are converted into employment forecast by occupational segments. In a second step, these forecast by occupational segment are further disaggregated to forecast of employment by occupational class. The forecast of the expansion demand by occupational segment are then transposed into forecast of expansion demand by education.

\footnotetext{
${ }^{5}$ This evaluation is based on relative forecasts only.
} 


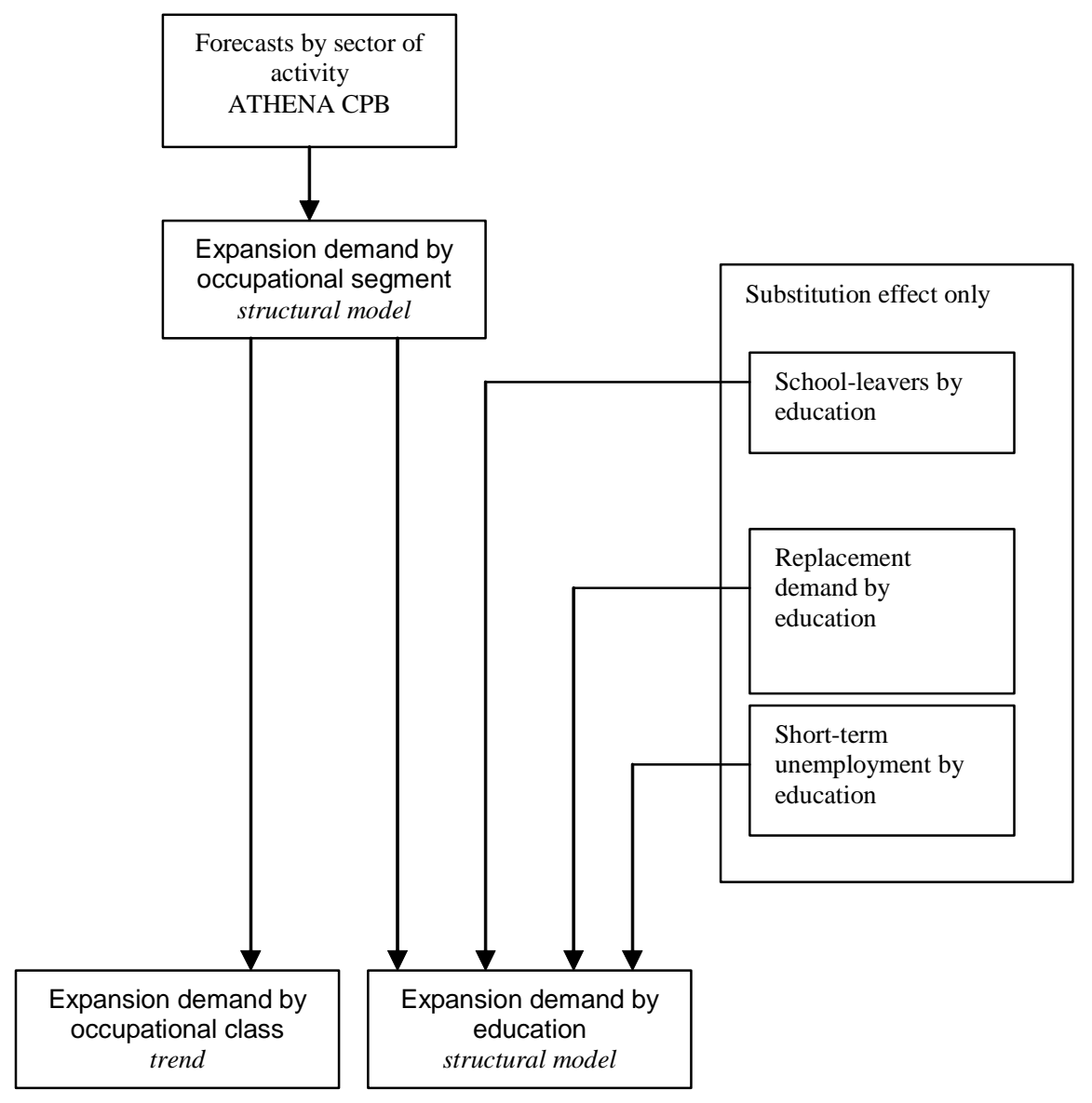

Figure 3: Overview of the methodology for expansion demand forecasts 


\section{Forecast by sector}

The employment forecast by sector are generated by CPB for the period 1997-2002 based on the optimistic scenario from the Centraal Economisch Plan 1997 (CPB, 1997). The dimension of these forecast is labour-year equivalents. Based on the CPB forecast of the so-called person/year ratio for each sector, indicating the ratio of persons by persons/year, we compute the for each sector the employment forecast in persons. The CPB employment forecast by sector are based on the National Accounts. These figures do not correspond exactly to the employment figure reported in the Labour Force Survey (LFS) held by Statistics Netherlands (CBS), upon which the analysis of employment developments by occupation and education are based. The differences between the two sources are among other due to differences in classifications of economic activities. Therefore, we use employment growth from the CPB rather than employment level to tackle this problem. This means that the total number of persons employed in each sector corresponds to the LFS figures. By applying the CPB growth on the LFS series of employment level means that 1997 is not an observation but rather a forecast itself.

\section{Occupational model}

In the occupational model, forecast of employment by sectors are transposed into employment forecast by occupational classes. This means that employment forecast are merely determined by demand factors. The expansion demand by occupation depends on the expected employment sector shifts as well as the expected changes in the occupational structure within sectors.

As depicted in Figure 3.1, the occupational model consists of two steps. Expansion demand by occupational segment is determined in a first step. The occupational segment classification used by ROA distinguishes 43 segments. In the second step, the expansion demand by occupational segment is disaggregated to occupational classes. The ROA distinguishes 127 occupational classes. Most segments consist of several occupational classes.

The main reason for proceeding in two steps is that Statistics Netherlands only reports the occupational employment within sectors when more than 5000 persons are observed. Therefore, where the employment share in certain classes are not reported, employment shares at the segment level are reported. 
In the first step, changes in the employment by occupational segment within sectors are estimated using LFS data from 1988-1997. Due to the short time series, Ordinary Least Squares (OLS) estimates are often insignificant. To solve this problem, a random coefficient model was developed and used for the first time in 1993 (see Borghans and Heijke (1994)). In the random coefficient model, the value of the parameters associated with each occupation are weighted by the average of on the one hand, the estimate of the parameter for the specific occupation concerned and on the other hand, the average estimate of all occupations in each sector. The weights used for each occupation decrease with the standard deviation of the parameters of the respective occupations. When the OLS estimates are unreliable, they are weighted so that they tend to the occupation average within sector. If the coefficient are reliable, the respective weight tends to one so that the random coefficient estimate is identical to the OLS estimate.

Since 1993, the first difference of the log of employment shares are used as dependent variables. This means that the model estimates the employment growth rate and not the employment level in each occupation within sector. Estimating growth rates instead of levels of employment shares, we implicitly assume that unexpected changes in the level will remain in the future. A drawback of this method is that the forecast are not by definition consistent with the sector forecast. In practice are the differences rather small and are corrected by re-scaling the occupational segments forecast.

In the model, besides a constant term, three explanatory variable are used: the growth rate of production capacity, the growth rate of hours worked per year (as stipulated in the contract) and the rate of unemployment. These variables are made available by CPB and used in the Athena-model. Even if each of the three explanatory variables are measured at the sector level, they may have different effects in different occupations. However, the average effect over all occupations within each sector is 0 . The interpretation of this model is then trivial. The expected growth of an occupation in a sector is equal to the total employment growth in this sector. The explanatory variables can lead to faster for some occupations and slower growth for others but the expected differences are in average equal to 0 .

The expansion demand by occupational segments aggregated over sectors is consecutively translated into expansion demand by occupational classes using the random coefficient model with a constant term only. 


\section{Educational model}

As mentioned earlier, employment is assumed to be essentially demanddriven. This implies that expansion demand is set equal to employment growth. The firms' demand for workers, in fact, arises primarily from the firms' need to fill in vacant jobs in order to carry out tasks in the production process. In contrast, the expansion demand by education needs not to be equal to employment growth by education. If an educational group is characterized by a supply shortage, employers will try to substitute these workers by workers with another educational background. Employers are still able to fill in vacancies in the various occupations but with workers with a different type of education than they first expected. The resulting employment level by educational groups depends therefore on both demand and supply factors. It is important to differentiate between the ex ante demand by education, that is the demand that would have resulted if shortages of workers were observed in none of the educational groups, and the ex post employment levels. (see Borghans and Heijke (1996) and De Grip et al. (1998)).

Trends observed in time-series are subject to both demand and supply determined factors. These trends can not be interpreted as demand trends. Indeed, if the employment grew fast in a given educational group and this growth is driven by shortages of workers with other educational backgrounds, then the trend can not be used to forecast future demand for workers with this education because supply conditions might change too in the future. Borghans and Heijke (1996) develop a model to take into account the substitution process between educational groups.

Figure 4 illustrates the structure of the model. The demand for workers with the various educational backgrounds is derived from the expansion demand by occupational segments based on the allocation matrix of workers with the various educational backgrounds to the various occupational segments in the last observation year (1997). Thereafter, forecast of the changes in the educational structure are made accounting for changes in the exogenous demand. Thereby, two effects are separated: i) educational upgrading that accounts for the increase in the educational level demanded in the various occupations, and ii) the increased concentration around the average educational level in each occupation. The second variable captures the

effects of the increase in the relative importance of education, compared to experience for instance, in the selection process.

In the next step, the ex ante demand forecast are confronted to the supply 
forecast. If for an educational group, demand exceeds supply then employers will substitute these workers by workers with other educational backgrounds. A shortage of workers with a given education leads to extra demand for workers with other educational backgrounds. In contrast, if for an educational group, supply exceeds demand then these workers will have to accept less attractive jobs in occupations where they will compete with workers with another educational background. After several iterations, the substitution process leads to a new equilibrium. The new equilibrium gives the demand net of (passive) substitution. The expansion demand with (passive) substitution indicates the demand for school-leavers with a given education accounting for the eventual shortages and/or surpluses of workers in other educational groups. The passive substitution does not account for changes in the educational group itself. A positive active substitution might be the ensuing effect of a drop in the wage rate associated to this education. The active substitution is added to the demand in the model because it would give a too optimistic representation of the labour market situation. The (passive) substitution demand is not presented in this report but is used to derive the Index of Labour Market Perspective (see Section 7).

The educational model has also been subject to modifications. For teachers in higher education, high and medium medical and paramedical occupations and theology higher occupations it was decided that substitution took place because in practice, there exist sharp distinctions between the occupational classes that compose these occupational segments.

\subsection{Empirical evaluation of expansion demand forecast}

\section{Expansion demand by occupational class}

Table 21 of the Appendix reports the forecasting errors and loss corresponding to the forecast of expansion demand bo occupational class. The table also contains the employment level in 1997, the forecast expansion demand and the employment realization in 2002 by occupational class. Striking is the result that for some occupational class, very good forecast have been produced. Indeed, for 8 out of the 127 occupations, there is almost no loss $($ Loss $=0.000)$. For some of these occupations, i.e. Library assistants, the employment level remained fairly constant which might explain why the forecast was so accurate. However, for some other occupations, i.e. Artists, Activity supervisors and employment intermediaries or even Graphic Designers, 


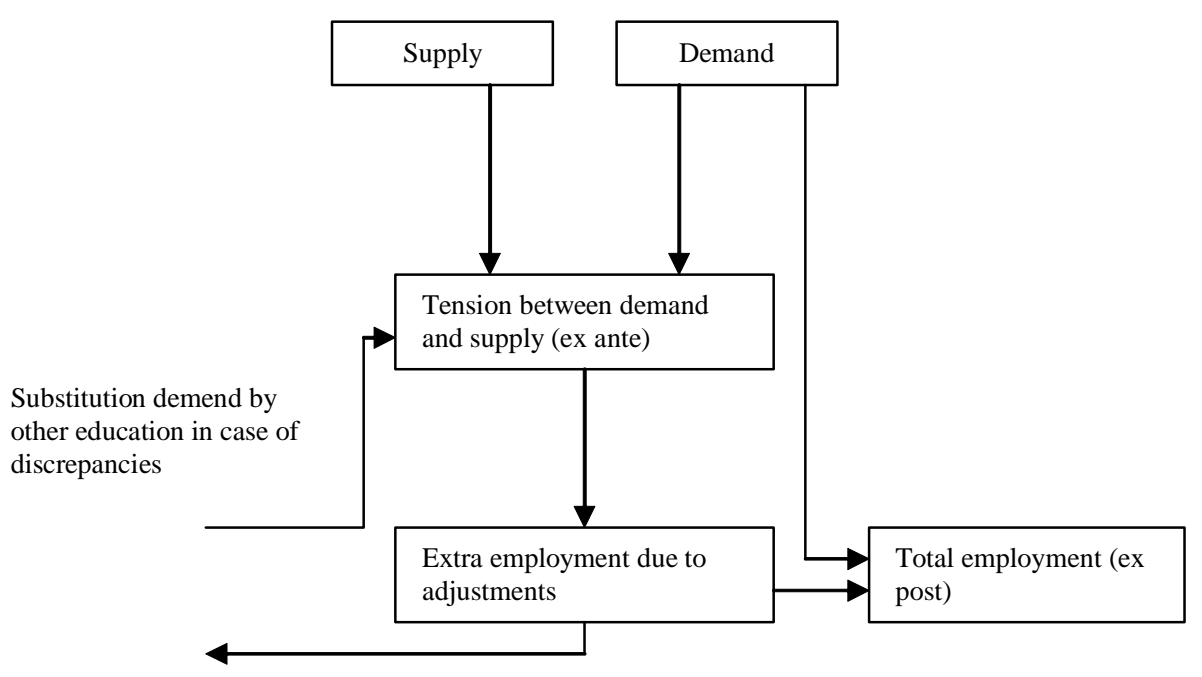

Substitution of other education in case of discrepancies

Figure 4: Structure of the demand for labour by education 
employment increased significantly $(7 \%, 12 \%$ and $31 \%$ respectively between 1997 and 2002) which indicates that the structural model used to forecast expansion demand accurately replicates the effects of economic variables on employment in these occupations.

However, for some occupations the model poorly predicted employment expansion between 1997 and 2002 as measured by the loss. For instance, the model forecast of expansion demand for Electronical engineers was $-6,500=$ $9,100-15,600$ whereas observed expansion demand is $-5,700$. Of course, employment in this type of occupation is very sensitive to business cycle whereas the model can only pick up the effect of structural economic variables. Cyclical variation blur the effect of structural economic variables and lead to a rather poor performance of the model to predict employment. Other problematic occupations are: Librarians, Material scientists, Stewards, Economists and Financial brokers.

Table 1: Total overview of the expansion demand forecast quality by occupational class.

\begin{tabular}{lcrc}
\hline \hline & $\begin{array}{c}\text { Average loss } \\
\text { forecast }\end{array}$ & $\begin{array}{c}\text { Average loss } \\
\text { SAB }\end{array}$ & Score \\
\hline forecast 2002 & & & \\
Absolute & 0.0268 & 0.0300 & 0.89 \\
Relative & 0.0399 & 0.0412 & 0.97 \\
& & & \\
forecast 2000 & & & \\
Absolute & 0.0309 & 0.0430 & 0.72 \\
Relative & 0.0214 & 0.0280 & 0.77 \\
\hline
\end{tabular}

Table 1 provides an overview of the quality of the forecast of the expansion demand by occupational class. The absolute average loss is lower than the absolute average loss for the forecast in 2000 whereas for the relative forecast the reverse is true. For the SAB forecast we also observe decrease of the absolute average loss and an increase of the relative average loss. However, since the absolute average loss of the $\mathrm{SAB}$ forecast decreased even more than the absolute average loss of the forecast and the relative average loss of the $\mathrm{SAB}$ increased less than the relative average loss of the forecast between 2000 and 2002, the score of both absolute and relative forecast has worsened 
(increased). The absolute forecast include $89 \%$ of the errors of the SAB forecast whereas the relative forecast include $97 \%$ of the errors of the SAB forecast.

It is striking that absolute forecast give rise to a better score than relative forecast, a result constantly observed since 1994. This indicates that, for the forecast, a smaller part of the loss arrises from the underestimation of the employment level than for the SAB forecast.

Table 2: Decomposition of expansion demand forecast by occupational classes.

\begin{tabular}{lrr}
\hline \hline & $\begin{array}{c}\text { Average loss } \\
\text { forecast }\end{array}$ & Score step by step \\
\hline SAB (absolute) & 0.0300 & - \\
Occupational structure 1997 & 0.0267 & 0.89 \\
Segment structure 1997 & 0.0264 & 0.99 \\
Forecast & 0.0268 & 1.02 \\
& & \\
\hline
\end{tabular}

As mentioned earlier in Section 3.2, the forecast of expansion demand by occupational class are derived in two steps. In the first step, forecast by sector of industry are translated into occupational segments forecast. In the second step, forecast by occupational segment are used to generate forecast by occupational class. It is interesting to evaluate the extent to which each step contributes to improve the quality of the forecast compared with Same As Before forecast that assume a fixed structure of employment within sectors and occupational segments.

Table 2 reports the results of this decomposition. The first row contains the SAB forecast, that is the forecast obtained assuming that both the occupational structure and the sector structure are constant in the economy. The second row contains the forecast derived by allowing for employment mobility between sectors but not between occupational segments within sectors. As indicated by the relatively low score (0.89), the average loss decreases remarkably. Only $89 \%$ of the SAB errors remain when allowing for sector mobility. Allowing for occupational mobility does not improve the forecast at all as indicated by the last two rows of Table 2 . 
This result is consistent with that obtained for the forecast of 2000 with respect to the improvement due to sector mobility. However, for the forecast of 2000, allowing for intra sector mobility between occupational segments improved significantly the forecast (score of 0.83) which contrasts sharply with the results obtained for the 2002 forecast as reported in the third row of Table 2 .

Table 3: Explanation of forecasting errors in relative expansion demand by occupational class.

\begin{tabular}{l|rrr}
\hline \hline Variable & Parameter & T-statistic & \\
& & & \\
Constant & 2.858 & 3.280 & $* *$ \\
Scale & 0.502 & 5.687 & $* *$ \\
Dispersion index & 0.034 & 1.278 & \\
Business sensitivity Index & 0.026 & 0.113 & \\
Underestimation coefficient & -0.007 & -0.571 & \\
& & & \\
\hline
\end{tabular}

Table 3 reports the factors that possibly explain the forecast errors and the variance of these forecast errors of the expansion demand forecast by occupational class. The underestimation coefficient is not significantly different from 0 which indicates that there are no systematic under or over estimation of the expansion demand by occupational class. This result seems to be recurrent since 1998 and contrast with earlier forecast for which overestimation was found. Since 1998 and the use of a random coefficient model, the forecast include less noise as the unreliable coefficients are corrected. The results once again speak in favour of the introduction of the random coefficient model.

The table also indicates that the size of the occupational class (scale effect) has a significant impact on the variance of the errors of the forecast. The scale effect is significantly larger than 0 as in previous studies but remains smaller than 1. This implies that forecast of expansion demand in large occupational classes are worse in levels but better in percentages than in small occupational classes. Moreover, it is interesting to note that the scale parameter has decreased compared to the previous report (0.80 in 2000) which could indicate that a possible cause for the worsening of the expansion demand forecast could be the increase of the number of occupational classes 
distinguished. In contrast, the dispersion index and the business sensitivity index have no significant effect on the variance of the errors.

\section{Qualitative evaluation}

In order to better evaluate the forecast and take into account a range of forecast rather than the forecast at their face-value, we assign to each forecast a qualitative characterisation. The classification of characterisations is defined as follows: Very low: $E D \leq-3,-3<E D \leq 3$ low, $3<E D \leq$ 11 average, $11<E D \leq 22$ high and $E D>22$ very high, where $E D$ is expansion demand, and the limiting values represent the expansion demand as percentage of occupational employment.

Table 4: Qualitative evaluation of expansion demand by occupational class (relative forecast).

\begin{tabular}{lrrrrrr}
\hline \hline & & Realization & & \\
Forecast & Very low & Low & Average & High & Very High & Total \\
Very low & 0 & 3 & 1 & 1 & 4 & 9 \\
Low & 9 & 1 & 3 & 5 & 2 & 20 \\
Average & 16 & 9 & 7 & 11 & 6 & 49 \\
High & 3 & 3 & 3 & 6 & 13 & 28 \\
Very high & 3 & 5 & 1 & 3 & 9 & 21 \\
Total & 31 & 21 & 15 & 26 & 34 & 127 \\
\hline
\end{tabular}

Table 4 gives a cross-tabulation of the characterisation of the realizations and the forecast. ${ }^{6}$ From the 127 occupational classes, 23 have been assigned the right characterisation, the characterisation of the realization. This means that $18 \%$ of the forecast has the right characterisation. If we add to this amount all occupational classes for which the characterisation of the forecast differ by just one category with the characterisation of the realization, we have 77 occupational classes. This means that $61 \%$ of the occupational classes has been assigned either the right characterisation or a characterisation differing by just one category. Note that $9 \%$ of occupational

\footnotetext{
${ }^{6}$ Herewith, the relative forecasts are used and not the absolute forecasts. The reason for this choice is that because of the over or underestimation of the total employment level the distribution of absolute forecast does not overlap anymore with the distribution of realizations.
} 
groups with less than 10,000 workers had the right characterisation and $37 \%$ had the right characterisation or almost. Wrong characterisations seem to occur more often for small occupations.

\subsection{Conclusion}

The main changes regarding expansion demand compared to previous forecast are the extension of the occupational classification from 93 to $127 \mathrm{occu}-$ pational groups. A second important change has occurred because of CBS's change of sector classification in 1994. In order to use the LFS data from 1988 to 1993, ROA had to estimate "what the LFS data for that period would have looked like " were the sector classification used in that period the same as the new one. This was possible since in 1994 data were generated using both the new and old classification. However, this has probably led to measurement errors and therefore errors in the forecast of expansion demand.

The evaluation of the expansion demand forecast provides the following global picture. There is a relatively high score indicator, though less than unity, compared to previous years that we argue to be mainly caused by the changes in sector classification. However, there is no systematic over or under estimation, a result consistent since 1998 and the introduction of the random coefficient model. Moreover, the analysis of the qualitative characterisation provides results of comparable magnitude to previous years. $60 \%$ of the occupational classes has been assigned either the right characterisation or a characterisation differing by just 1 category.

\section{Replacement demand}

\subsection{Introduction}

The expansion demand as exposed in the previous section, is not the only source of demand for new entrants in the labour market. A second component of the forecast in the Information system concerns the replacement demand, as resulting from (temporary) flows in and out of the labour market. In section 4.2 the replacement methodology for the 1997-2002 forecast is described. The results of the evaluation of the replacement demand forecast are reported section 4.3 . 


\subsection{Forecasting method}

Besides the expansion demand, the job openings by occupation or education consist of a second important component: the replacement demand. Even in occupations for which employment shrinks, new workers are observed flowing in because for instance some workers retire from this occupation. The replacement demand is strongly depending on the age structure within occupations. Occupations with a high concentration of older workers witness higher outflow than occupations that consists mainly of young workers. The same stylized fact is observed in occupations with for instance high shares of female employment in the middle age classes.

The methodology used to forecast replacement demand for the period 1997-2002 is the same as the one used in to forecast replacement demand in the period 1993-1998 and based on an extension of Willems and de Grip (1993) and documented in Willems (1996). Replacement demand concerns only the exit of workers that are actually replaced. This implicitly means that in situation of tight labour market, replacement demand will be smaller than the total outflow of workers.

The main reason for not just considering flows in and out of the labour market, is that gross flows are not available at the level of aggregation needed for our purpose. Therefore, a different methodology has been developed to resolve this issue. Replacement demand forecast are obtained by comparing the age distribution of the people working in each categories considered (educational group or occupational class). If the population is divided into 5 year cohorts, after an interval of 5 years everyone will have moved up one age group. By aggregating across the cohorts, it is thus possible to establish approximately the proportion of each occupational class who enter and leave that class. These forecast are corrected for the expected changes in the labour market participation by gender and age cohorts for the whole labour force. Besides correcting for participation, a comparable control for business cycle effects is included in the analysis.

The cohort methodology depicted above has three main problems. First, the issue of measurement errors arrises. Because the method requires to disaggregate the data in very narrowly defined groups of workers, employment in each of these groups might not be representative of the labour force. To solve this problem three possibilities are feasible. Clements (1995) has shown that the opinion of an analyst often leads to favorable effects on the uncertainty of a forecasting method. For the forecast to 2002, it was tested 
whether the estimated parameters of the model were plausible or not and those not plausible were adjusted ad hoc. A second method is to compare several years instead of two years only. This method was first used for the 1993-1998 forecast. The third method is to use an econometric method that accounts for these measurement errors. In Willems (1996), a random coefficient model has been developed so that flow coefficients for some categories that are less reliable are heavily corrected and tend to be close to the mean coefficient. This method allows for instance the unreliable results for Welding and Construction workers to be replaced by the average flow estimates of the higher cluster to which these workers belong, i.e. Technical and Industry workers. This methodology was first used for the 1995-2000 forecast.

A second problem in the forecasting of replacement demand concerns the relationship between outflow and expansion demand. As mentioned earlier, shortage supply in the labour market can come about because of a high flow of workers out of the labour market or because of a low inflow of new entrants. In replacement demand model we implicitly assume that the adjustments in case of declining employment come about because of higher outflow of workers while by definition inflow of workers remains unaffected. From experience in the previous evaluations this method seems to be closer to reality than assuming that declining employment come about by a low inflow of workers while outflow remains constant.

A third problem, is that only the net effects for each cohort are registered. If there are people within one cohort who are leaving and entering an occupational class, it is in fact only the balance of these flows which is recorded. This problem is, in part, solved by dividing those already working in an occupational class by age and gender. In other words, the workers are, so far as possible, divided into homogenous groups. In each group the flows should be in only one direction, whether that be people leaving or entering the occupational class. For men this solution is apparently accurate enough, because they often enter or leave a particular occupational class at specific ages. One exception to this is the group of young people, who quite frequently change their occupation in the first years after entering the labour market. Problems can also arise in measuring the movements of women, because they often leave the market temporarily and re-enter later. If there are some women in a given age group re-entering an occupational class, and other women of the same age group leave that class, only the net flow will be recorded. This problem could be reduced if the female population could be further divided into one group who are more likely to enter the occupation 
and another who are more likely to leave, but it would be almost impossible to find characteristics which would adequately distinguish the two groups. An alternative would be to use the information in the LFS survey which derives from the question to respondent's most important activity in the previous year. Another possibility proposed in Vlasbom et al. (2000), is to split the net flows into in- and outflows so that a better insight of adjustments in the labour market is available.

\subsection{Empirical evaluation of replacement demand fore- cast by occupational class}

An inherent problem with the evaluation of the forecast of replacement demand is that replacement demand itself is not observable. We therefore need to construct the observed replacement demand for the period 1997-2002. To construct 'observed' replacement demand, we use the same methodology as to forecast replacement demand, the so -called 'Net-method' in which simultaneous in and outflow is not observed. As reference forecast to evaluate replacement demand we use the weighted average of replacement demand forecast, where weights are employment shares in 1997, since the Same as Before forecast provides a meaningless reference forecast for replacement demand.

Table 22 of the Appendix provides an overview of the quality of the forecast of replacement demand by occupational class. The table reports the reference forecast and loss for each occupational class. As in the previous evaluation of forecast, replacement demand is significantly overestimated. Overall, the forecast of replacement demand by occupational class overestimate the realization of replacement demand by 194,000. Although this figures is quite large, it is in sharp contrast with the 440,000 overestimation obtained in 1998 and 575,000 in 2000. The overestimation problem seems to be significantly declining since 1998. The five largest overestimation are recorded for Construction workers, Metal workers, Receptionists and administrative employees, Sales assistants and Auxiliary catering and service workers. These five occupations account for $47 \%(92,000)$ of total overestimation. In contrast, replacement demand in some occupational classes has been underestimated. The five largest underestimated occupational classes are: Drivers, Accountants and secretaries, Commercial staff, Managing directors and Shopkeepers. 
Up until 1998, the number of occupational classes for which replacement demand was underestimated had been decreasing sharply from $90 \%$ in 1992 to $15 \%$ in 1998. Since 1998 however this proportion seems to be increasing slightly, i.e. $20 \%$ in 2000 and $25 \%$ in this evaluation towards its mean $50 \%$. Moreover, it should be noted that the average magnitude of underestimation has been decreasing since 1992 which together with the sharp decrease of the total magnitude of overestimation indicates an overall improvement in the accuracy of the replacement demand forecast. Note finally that in each previous evaluation different occupational classes have been over- or underestimated. There is therefore no systematical pattern of either over or underestimation observed since the first evaluation in 1992.

Another indicator of the quality of the forecast is the loss. Up until 1994, the largest losses were systematically observed for Cultural occupational classes. Since 1998, this seems not to be the case anymore and the largest losses are spread over the occupational spectrum. In 2002, the big 'losers' are Nursing aids and student nurses and shelf stockers (with an average loss of 0.0654 and 0.0718 respectively).

Table 5: Total overview of the replacement demand forecast quality by occupational class.

\begin{tabular}{lcrc}
\hline \hline & $\begin{array}{c}\text { Average loss } \\
\text { forecast }\end{array}$ & $\begin{array}{c}\text { Average loss } \\
\text { SAB }\end{array}$ & Score \\
\hline $\begin{array}{l}\text { forecast 2002 } \\
\text { Absolute }\end{array}$ & 0.0039 & 0.0031 & 1.26 \\
Relative & 0.0024 & 0.0022 & 1.10 \\
forecast 2000 & & & \\
Absolute & 0.0107 & 0.0090 & 1.19 \\
Relative & 0.0026 & 0.0021 & 1.23 \\
\hline
\end{tabular}

Table 5 indicates the overall forecast quality of the replacement demand by occupational class. The table shows that the average loss of the absolute forecast and SAB have decreased tremendously between 2000 and 2002 from 0.011 to 0.004 and from 0.009 to 0.0031 respectively. In contrast, the average loss for the relative forecast and SAB remained constant. Whereas the score for the absolute forecast has increased between 2000 and 2002, the score for 
the relative forecast indicates that the distribution of replacement demand forecast has improved.

Table 6: Explanation of forecasting errors in relative replacement demand by occupational class.

\begin{tabular}{l|rrr}
\hline \hline Variable & Parameter & T-statistic & \\
& & & \\
Constant & -3.063 & -3.282 & $* *$ \\
Scale & 0.949 & 10.078 & $* *$ \\
Dispersion index by sector & 0.003 & 0.093 & \\
Underestimation coefficient & -0.607 & -6.204 & $* *$ \\
& & & \\
\hline
\end{tabular}

Table 6 reports the factors that possibly explain the forecast errors and the variance of these forecast errors of the replacement demand forecast by occupational class. The scale effect is significantly larger than 0 as in previous studies but the magnitude is larger than in previous studies. It remains smaller than 1 though which implies that forecast of replacement demand in large occupational classes are worse in levels but better in percentages than in small occupational classes. The Gini-Hirschmann dispersion index has no significant impact on the variance of the errors.

The table clearly indicates that the replacement demand is overestimated, since the underestimation coefficient is negative and significant. The magnitude of the underestimation coefficient is far better than in $2000(-0.97)$ but of the same magnitude than in previous evaluations, compared with -0.67 in 1998 for instance. In replacement demand, the forecast reference is not "Same As Before," but the average replacement demand weighted by the relative employment size of each occupational class. Therefore, the underestimation coefficient refers to differences between the forecast and the average forecast. This means that the replacement demand by occupational class contains a lot of noise.

\section{Qualitative evaluation}

In order to better evaluate the forecast and take into account a range of forecast rather than the forecast at their face-value, we assign to each forecast a qualitative characterisation. The classification of characterisations 
is defined as follows: Very low: $R D \leq 12,12<R D \leq 15$ low, $15<$ $R D \leq 20$ average, $20<R D \leq 26$ high and $R D>26$ very high, where $R D$ stands for replacement demand and the limiting values are in percentages of employment in 1997.

Table 7: Qualitative evaluation of replacement demand by occupational class (relative forecast).

\begin{tabular}{lrrrrrr}
\hline \hline & \multicolumn{5}{c}{ Realization } & \\
Forecast & Very low & Low & Average & High & Very High & Total \\
Very low & 14 & 9 & 6 & 2 & 0 & 31 \\
Low & 12 & 7 & 9 & 3 & 0 & 31 \\
Average & 9 & 11 & 15 & 7 & 2 & 44 \\
High & 0 & 1 & 5 & 4 & 3 & 13 \\
Very high & 1 & 1 & 1 & 2 & 3 & 8 \\
Total & 36 & 29 & 36 & 18 & 8 & 127 \\
\hline
\end{tabular}

Table 7 indicates the extent to which the characterisation of the forecast corresponds with the characterisation of the realizations by occupational class. From the 127 occupational classes, 43 have been assigned the right characterisation, the characterisation of the realizations. This means that $34 \%$ of the occupational classes has been correctly described. Moreover, 58 occupational classes have been assigned a characterisation just one category away from the right category. This means that $80 \%$ of all occupational classes has the right characterisation or almost. Note that $37 \%$ of occupational groups with less than 10,000 workers had the right characterisation and $91 \%$ had the right characterisation or almost. There is a small tendency of large occupations to be attached a wrong characterisation.

\subsection{Empirical evaluation of replacement demand fore- cast by educational type}

Table 23 of the Appendix provides an overview of the quality of the forecast of replacement demand by educational type. The table reports the realization of the replacement demand as well as the forecasting error and the loss by educational type. As previously observed for the replacement demand by occupational class, the forecast of replacement demand by education tends to 
overestimate actual replacement demand. Although, total overestimation is 133,565 which is about half the total overestimation observed in the previous evaluations (320,000 in 1998). For 78 of the 114 educational types distinguished (i.e. 68\%), we observe an overestimation of replacement demand. The most overestimated educational types are: Lower general secondary education, PVE Commerce, PVE Community care, hotel and catering, IVE Community care and IVE Police, fire and defense. These five educational types account for $59 \%$ of the total overestimation of replacement demand by education. The largest average losses are recorded for PVE Administration, textile and leather trades, IVE Technical laboratory, IVE Tourism and recreation and HVE Tourism and recreation.

Table 8: Total overview of the replecement demand forecast quality by education.

\begin{tabular}{lccc}
\hline \hline & $\begin{array}{c}\text { Average loss } \\
\text { forecast }\end{array}$ & $\begin{array}{c}\text { Average loss } \\
\text { SAB }\end{array}$ & Score \\
\hline forecast 2002 & 0.0039 & 0.0040 & 0.98 \\
Absolute & 0.0032 & 0.0035 & 0.91 \\
Relative & & & \\
forecast 2000 & 0.0043 & 0.0023 & 1.85 \\
Absolute & 0.0022 & 0.0015 & 1.37 \\
Relative & & & \\
forecast 1998 & 0.0062 & 0.0035 & 1.79 \\
Absolute & 0.0021 & 0.0010 & 2.03 \\
Relative & & & \\
\hline
\end{tabular}

Table 8 provides an overview of the average loss of the forecast of replacement demand by educational type. The average loss for the absolute forecast has decreased from 0.0062 in 1998 to 0.0043 in 2000 and 0.0039 while the average loss of the SAB has slightly increased. The average loss of the relative forecast has however increased by $50 \%$ but at the same time the average loss of the relative SAB more than tripled between 1998 and 2002. This means that both the score of the absolute and relative forecast have tremendously decreased. The replacement demand forecast by educational type have improved significantly since 1998.

Table 9 reports the factors that possibly explain the forecast errors and the variance of these forecast errors of the replacement demand forecast by 
educational type. The scale effect is of the same magnitude (and significant) as for the replacement demand by occupation and indicate that forecast for large educational types are less accurate levels but more accurate in percentages than small educational types. Interestingly enough, the dispersion index by occupation has a negative and significant effect on the variance of the forecasting errors. The more spread workers with a given educational type are over the various occupational groups, the smaller the variance of the forecasting errors and therefore the more accurate the forecast.

Table 9: Explanation of forecasting errors in relative replacement demand by education.

\begin{tabular}{l|rrr}
\hline \hline Variable & Parameter & T-statistic & \\
& & & \\
Constant & -2.000 & -2.265 & $* *$ \\
Scale & 0.865 & 9.709 & $* *$ \\
Dispersion index by occupation & -0.053 & 2.226 & $* *$ \\
Dispersion index by sector & 0.028 & 1.150 & \\
Share of female workers & 0.003 & 0.857 & \\
Underestimation coefficient & -0.386 & -3.402 & $* *$ \\
& & & \\
\hline
\end{tabular}

The underestimation coefficient is negative and significant at $5 \%$ although significantly smaller than -1 . This means that the forecast of replacement demand by educational types are overestimated. However, compared with previous results, -1.19 in 1998 and -1.46 in 2000, the magnitude of the coefficient seems to be decreasing through time indicating a global improvement in the accuracy of the forecast.

\section{Qualitative evaluation}

In order to better evaluate the forecast and take into account a range of forecast rather than the forecast at their face-value, we assign to each forecast a qualitative characterisation. The classification of characterisations is defined as follows: Very low: $R D \leq 12,12<R D \leq 17$ low, $17<R D \leq$ 22 average, $22<R D \leq 25$ high and $R D>25$ very high, where $R D$ is replacement demand, and the limiting values are replacement demand as a percentage of employment in 1997. 
Table 10: Qualitative evaluation of expansion demand by education (relative forecasts).

\begin{tabular}{lrrrrrr}
\hline \hline & & & Realization & & & \\
Forecast & Very low & Low & Average & High & Very High & Total \\
Very low & 7 & 4 & 1 & 2 & 0 & 14 \\
Low & 5 & 15 & 17 & 1 & 0 & 38 \\
Average & 4 & 17 & 18 & 3 & 4 & 46 \\
High & 1 & 2 & 3 & 0 & 4 & 10 \\
Very high & 1 & 0 & 2 & 1 & 1 & 5 \\
Total & 18 & 38 & 41 & 7 & 9 & 113 \\
\hline
\end{tabular}

Table 10 indicates the extent to which the characterisation of the forecast corresponds with the characterisation of the realizations by educational characterisations. From the 113 educational groups, 41 have been assigned the right characterisation, the characterisation of the realizations. This means that $36 \%$ of the educational groups has been correctly described. Moreover, 54 educational groups have been assigned a characterisation just one category away from the right category. This means that $84 \%$ of all educational groups has the right characterisation or almost. Note that $50 \%$ of educational types with less than 10,000 workers had the right characterisation and $77 \%$ had the right characterisation or almost. There is no systematic relationship between wrong characterisation and employment size.

\subsection{Conclusion}

Although the score by occupation remains larger than unity, we observed a large decrease between 2000 and 2002. Although the forecast are still overestimated, the decrease in the score by occupation has been accompanied by a large decrease in the magnitude of over estimation of the forecast. The quality of the qualitative characterisation also improved notably. While $73 \%$ of the occupational classes had the right characterisation or almost in 2000, in 2002 this figure increased to $80 \%$.

The results of the evaluation of replacement demand by education are encouraging too. Indeed, for the first time, the score by education is lower than unity and decreased by $33 \%$ between 2000 and 2002.There is however 
still evidence of systematic overestimation but here too of a magnitude significantly lower than in previous studies $(-0.39$ in 2002 compared to -1.46 in 2000 for instance). These improvements are to be seen in the qualitative evaluation too. $84 \%$ of educational groups have the right characterisation or almost the right characterisation compared to $77 \%$ in 2000 .

\section{Job Openings}

\subsection{Introduction}

The demand for entrants workers in the labour market is determined by the total number of job openings. These job openings are made of the expansion demand and replacement demand discussed in the two previous sections. The demand for workers may increase either because of economic growth or a larger outflow of workers. In this section the job openings forecast for the period 1997-2002 are evaluated. First the methodology used to derive the forecast is described and then the forecast by occupational class are evaluated.

\subsection{Forecasting method}

Vacancies for new entrants are made available because of economic growth or because workers have left their job and left open their position for grab. Inventories of job openings are differentiated between educational groups and occupational classes for which the expected expansion demand is positive and those for which the expansion demand is negative. ${ }^{7}$ For occupational classes associated with positive expansion demand, the number of job openings is equal to the sum of the expansion demand and the replacement demand. In contrast, job openings for occupational classes associated with expected negative expansion demand is assumed to be equal to replacement demand. The replacement demand model already accounts for the outflow of workers that are not replaced. This implicitly means that the inflow of workers is only required to accommodate the replacement needs.

Job openings in occupational class $i$ are defined by:

\footnotetext{
${ }^{7}$ Note that the replacement demand is by definition positive.
} 
Job Openings $_{i}=$ Replacement demand $_{i}+\max \left\{\right.$ Expansion demand $\left._{i}, 0\right\}$

\subsection{Empirical evaluation of job openings forecast}

As indicated in Equation 7, the quality of the forecast of job openings are determined by the quality of the forecast of expansion and replacement demand. This means that the errors made in forecasting expansion demand could either magnify or compensate the errors made in forecasting replacement demand. In this chapter, we investigate the extent to which each component contributes to forecasting errors in job openings. Since forecast of expansion demand are not evaluated for the various educational types, ${ }^{8}$ the analysis focuses on job openings by occupational classes.

Table 24 of the Appendix provides an overview of the quality of the forecast of job openings by occupational class. The table reports beside the forecast and realization of job openings, the forecasting errors and the average loss. The total forecasting errors indicate a tendency of the job opening forecast to underestimate job openings. Forecasting errors add up to 62,811 which is to be contrasted with the total of 260,000 observed in 1998 . 61 out of the 127 occupational types, or $48 \%$ are actually underestimated which is very close to the mean of $50 \%$. The largest underestimation are observed for Managers, Commercial staff, Programmers, System analysts and Information scientists. Together these occupational classes account for $200 \%$ of the underestimation.

As mentioned earlier, the errors of the job openings are a mix of the errors of expansion demand and errors of replacement demand. These two components could affect job openings in the same direction or in opposite direction. This means that a large positive error for expansion demand could be combined with a large negative error for replacement demand and lead to a small error for job openings. Regarding the five occupations for which a

\footnotetext{
${ }^{8}$ The reason for that is that in our model, employment growth by educational type is not equal to expansion demand by educational type. This gap is due to allocation and substitution processes in the labour market. In other words, excess supply and demand for certain types of education are resolved by substituting between the different types of workers. Therefore, the ex ante expansion demand is not equal to the ex post employment growth.
} 
large underestimation was recorded, expansion demand was underestimated to a large extent whereas replacement demand was slightly overestimated. For these five occupations, the errors of the components of job openings have opposite signs, i.e. underestimation of expansion demand and overestimation of replacement demand but with a dominant effect of expansion demand.

The five occupational classes for which forecast of job openings are overestimated most are: Construction workers, Metal workers, Production planners, Sales assistants and Catering personnel. The total demand is overestimated by at least 13,000 for these occupational classes.

The largest losers are: Agricultural and technical teachers (1st degree and UE), Teachers of economic and administrative subjects (2nd and 3rd degree), Managers and Information scientists that all are underestimated and Stewards that is overestimated, all with a loss of at least 0.489.

Table 11: Total overview of the job opening forecast quality by occupational class (relative).

\begin{tabular}{lrrr}
\hline \hline Composition & $\begin{array}{c}\text { Average loss } \\
\text { forecast }\end{array}$ & $\begin{array}{c}\text { Average loss } \\
\text { SAB }\end{array}$ & Score \\
\hline Expansion demand & 0.0399 & 0.0412 & 0.97 \\
Positive expansion demand & 0.0336 & 0.0354 & 0.95 \\
Replacement demand & 0.0024 & 0.0022 & 1.10 \\
Covariance expansion and & & & \\
replacement demand & -0.0035 & -0.0028 & \\
Job openings & 0.0291 & 0.0320 & 0.91 \\
& & & \\
\hline
\end{tabular}

As mentioned earlier, the forecasting errors of job openings depend on both its components, i.e. forecasting errors in expansion demand and replacement demand. In Table 11, the decomposition of the average loss of the relative forecast of job openings is presented. The first component is the expansion demand. Expansion demand only contributes to job openings when positive. Note that by definition the average loss of the positive expansion demand is smaller than the average loss of expansion demand. The average loss for the positive expansion demand is 0.0336 and the average loss of the replacement demand 0.0024. This implies that the total average 
loss for job openings should be equal 0.0360, were both expansion and replacement demand independent. As mentioned earlier, there is a negative relationship between expansion and replacement demand. The covariance of both components is equal to -0.0035 . This leads to an average loss for the job openings of 0.0291 instead of 0.0360 in case of independence between both demand components. ${ }^{9}$ Although theoretically we should expect either no relationship or a positive relationship between expansion and replacement demand we find empirically a negative relationship. It is important to note however, that this unexpected result seems to be driven by the data rather than by the methodology used since the SAB average loss analysis exhibits an similar negative covariance between expansion and replacement demand. Note also that, the average loss has increased compared to the previous evaluations, 0.0291 compared to 0.0154 in 1998 and 0.0136 in 2000. This results principally from the large increase in the average loss in expansion demand.

\section{Qualitative evaluation}

In order to better evaluate the forecast and take into account a range of forecast rather than the forecast at their face-value, we assign to each forecast a qualitative characterisation. The classification of characterisations is defined as follows: Very low: $J O \leq 12,12<J O \leq 18$ low, $18<J O \leq 31$ average, $31<J O \leq 48$ high and $J O>48$ very high, where $J O$ is Job Opening.

Table 12: Qualitative evaluation of job openings by occupational class (relative forecasts).

\begin{tabular}{lrrrrrr}
\hline \hline & & \multicolumn{3}{c}{ Realization } & & \\
Forecast & Very low & Low & Average & High & Very High & Total \\
Very low & 0 & 0 & 0 & 0 & 0 & 0 \\
Low & 5 & 6 & 2 & 2 & 1 & 16 \\
Average & 8 & 14 & 21 & 10 & 6 & 59 \\
High & 0 & 4 & 11 & 10 & 17 & 42 \\
Very high & 0 & 2 & 4 & 2 & 2 & 10 \\
Total & 13 & 26 & 38 & 24 & 26 & 127 \\
\hline
\end{tabular}

\footnotetext{
${ }^{9}$ Note that $\operatorname{Var}(a+b)=\operatorname{Var}(a)+\operatorname{Var}(b)+2 \operatorname{Cov}(a, b)$.
} 
Table 12 indicates the extent to which the characterisation of the forecast corresponds with the characterisation of the realizations by occupational class. Out of 127 occupational classes, 39 have received the right characterisation. This means that $31 \%$ of the occupational classes has been assigned the right characterisation which is rather consistent with previous results (compared to 1998, 29\%). Moreover, 61 occupational classes have been assigned a characterisation just one category away from the right category. This means that $79 \%$ of all occupational classes has the right characterisation or almost which is in between the previous studies (60\% in 1998 and 84\% in 2000). Note that $20 \%$ of occupational groups with less than 10,000 workers had the right characterisation and $63 \%$ had the right characterisation or almost. Wrong characterisation seems to occur more often for small occupations.

\subsection{Conclusion}

Since job openings depend heavily on replacement and expansion demand, the evaluation of job openings reflects the results found in the previous sections of this study. The score has increased from 0.77 to 0.91 between 2000 and 2002 mainly because of the increase in the expansion demand score following the sector classification change by CBS. This results traces also in the qualitative characterisation. While $84 \%$ of the occupational classes had the right characterisation or almost in 2000, this figure dropped to $79 \%$ in 2002 .

\section{Supply}

\subsection{Introduction}

On the supply side of the labour market, the most important component is the forecast of school-leavers inflow. These forecast are based on forecast on educational achievement made by the Ministry of Education, Culture and Science. We transpose these forecast into the expected number of schoolleavers by educational group using additional information. In this section, we first provide a short description of the methodology of the supply forecast and then present the results of the evaluation of the forecast for the period 1997-2002. 


\subsection{Forecasting method}

The forecast for the inflow in the labour market by educational groups (ROAclassification) are based on the reference estimates for 1997 (see Ministry of Education, Culture and Science, 1997) The reference estimate gives forecast of the number of pupils in full and part-time education, the number of obtained diplomas and the number of recent graduates. The reference estimate is the successor of the SKILL-education prognoses that was used for earlier forecast. The reference estimate gives in contrast to the SKILL-forecast also forecast of the number of recent graduates by type of school. Previously, the number of school-leavers was based on the number of graduates corrected using additional information for the number of graduates continuing education. The forecast of the outflow from educational system follows now directly from the reference estimate so that these additional information is no longer necessarily.

The methodology used for the forecast for 2002, is to a large extent similar to the methodology used for the forecast in previous reports. The model is best seen is two steps. In the first step, the forecast are set up equal to the expected outflow of full-time students in regular education. In the second step, this outflow is corrected for par-time students, not regular education and adult education. In the reference estimate, forecast consist of outflow of student with or without diploma. For those without diploma, the highest achieved previous education is considered. This is done with the help of the educational matrix 1995 of Statistics Netherlands (CBS). On this point, the methodology has been improved. For earlier forecast, the highest completed preparatory education was determined assuming that students without diploma were proportionally distributed over the various educational groups. Since 1995, preparatory education is also accounted for. When pupils did not obtain any diploma in their previous education either, then we look further back in their educational career.

As a result, this procedure provides the number of future school-leavers by educational type. The classification used in the reference estimate is different from the one used by ROA. The forecast by educational types are obtained using various data sources for which a key exists between both classifications. Hereby we made used of the Complete pupil count 1994/1995, the 'WO-verdeelraming', single CBS-pupil statistics and various other data sources. It is further assumed that the distribution of school types over the educational groups is constant through time. 
With the forecast of outflow of regular education, the total future inflow of recent graduates on the job market is determined. Those who flow out from regular full time education can also flow to a form of non-regular full time education, part time training, or vocational education for adults. If someone graduates from such training program and the training corresponds to a higher level, then the inflow of school-leavers with the preparatory training to which that person belongs decreases whereas the inflow of school-leavers with the continuing education increases. ${ }^{10}$

In the second step, the forecast are therefore redistributed between the outflow of regular and full time education on the one hand and part time, non regular and adult education on the other hand. To this aim, additional data sets are necessary. In 1997 a new large data set was used for the first time instead of the many small data sets in previous years. This new data set is the Education account (Onderwijsrekeningen) of Statistics Netherlands (CBS). Moreover, for the outflow of school-leavers from apprenticeship in the labour market, we used the Referentieraming 1997 and differentiated these outflows using the Education accounts.

The inflow of school-leavers in the labour market of for instance nonregular education are therefore depending on the availability of data and on a subjective judgement of how each training increases qualifications. Furthermore, it is quite difficult to assess whether all relevant educational streams have been taken into account in the model. For this reason, the education accounts of Statistics Netherlands (see Matheeuwsen and the Grip, 1997) are used for non-regular education. The education accounts contain information on as well the past followed trainings as the training that one follows at the moment of inquiry. Based on this information, the extent to which the extra education one follows is at a higher educational level or in a different fields can be assessed more consistently. An important advantage of the education accounts is further that they are based on the demand side of the labour market just as the ROA-forecast.

\footnotetext{
${ }^{10}$ Herewith, is assumed that the number of persons that choose non-regular education or part time education and does not finish this training in the period of the forecasts is outweighted by the number of persons that started the non-regular or part time education before the forecast period and finished it within this period.
} 


\subsection{Empirical evaluation of supply by type of educa- tion}

The forecast of the supply of labour by educational type is evaluated using the Reference estimates for 2002 made by the Ministry of Education, Culture and Science. Table 25 of the Appendix provides an overview of the quality of the forecast of supply by educational type. The table reports beside the reference forecast (Same As Before), the forecast and realization of supply, the forecasting errors and the loss by educational type.

The total errors indicate an underestimation of supply, i.e. 327,464. The five educational types for which the largest underestimation is observed are: Lower general secondary education, PVE Administrative, textile and leather trades, PVE others, Higher general secondary education and IVE Social and cultural. These five educational types account for $81 \%$ of the total underestimation.

In contrast, for 8 out of the 113 educational types the forecast are very accurate with no loss observed, i.e. loss $=0.000$. These eight educational types are: Primary education, PVE Transport and harbour, HVE Teacher training languages, HVE Teacher training health, HVE Environment sciences, HVE Mechanical engineering, HVE Nursing and paramedical services and UE Dentist.

Table 13 provides an overview of the quality of the forecast of supply by educational type. Although the scores of both the absolute and relative forecast are very good and improved compared to previous studies, we note that the magnitude of the average loss has increased significantly compared to 1998 and 2000. As seen in the previous table, this result is mainly driven by the average score of three educational types, namely: lower economics, intermediate agricultural and intermediate environment educational types. These three groups indeed account for $2 / 3$ of the average loss of both the forecast and the SAB. Moreover, once these three groups excluded, the scores of both the absolute and relative forecast improve remarkably from 0.82 to 0.67 .

\section{Qualitative evaluation}

In order to better evaluate the forecast and take into account a range of forecast rather than the forecast at their face-value, we assign to each forecast a qualitative characterisation. The classification of characterisations 
Table 13: Total overview of the supply forecast quality by education.

\begin{tabular}{lrrr}
\hline \hline & $\begin{array}{c}\text { Average loss } \\
\text { forecast }\end{array}$ & $\begin{array}{c}\text { Average loss } \\
\text { SAB }\end{array}$ & Score \\
\hline forecast 2002 & & & \\
Absolute & 0.0369 & 0.0452 & 0.82 \\
Relative & 0.0346 & 0.0393 & 0.88
\end{tabular}

Adjusted forecast 2002

$\begin{array}{llll}\text { Absolute } & 0.0117 & 0.0175 & 0.67 \\ \text { Relative } & 0.0132 & 0.0196 & 0.67\end{array}$

forecast 2000

$\begin{array}{llll}\text { Absolute } & 0.0146 & 0.0146 & 1.00\end{array}$

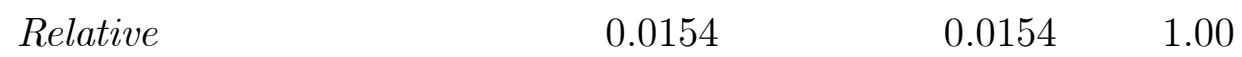

Adjusted forecast: educational groups Lower education Economics

Intermediate education Agriculture and Breeding and,

Intermediate education Environment are excluded

is defined as follows: Very low: $S \leq 6,6<S \leq 14$ low, $14<S \leq 26$ average, $26<S \leq 38$ high and $S>38$ very high, where $S$ is supply, and the limiting values represent inflows in percentages of employment.

Table 14 indicates the extent to which the characterisation of the forecast corresponds with the characterisation of the realizations by educational characterisation. Out of 113 educational characterisations, 39 have received the right characterisation. This means that $35 \%$ of the educational characterisations has been assigned the right characterisation which is rather consistent with previous results (compared to 2000, 33\%). Moreover, 54 educational groups have been assigned a characterisation just one category away from the right category. This means that $82 \%$ of all educational characterisations has the right characterisation or almost (compared to $78 \%$ in 2000). Note that $82 \%$ of educational types with less than 10,000 workers had the right characterisation and $96 \%$ had the right characterisation or almost. Wrong characterisation seems to occur more often for educational types with large employment size. 
Table 14: Qualitative evaluation of supply by education (relative forecasts).

\begin{tabular}{lrrrrrr}
\hline \hline & & Realization & & \\
Forecast & Very low & Low & Average & High & Very High & Total \\
Very low & 2 & 1 & 2 & 0 & 2 & 7 \\
Low & 2 & 9 & 4 & 2 & 1 & 18 \\
Average & 0 & 16 & 13 & 9 & 0 & 38 \\
High & 3 & 2 & 10 & 7 & 4 & 26 \\
Very high & 0 & 1 & 7 & 8 & 8 & 24 \\
Total & 7 & 29 & 36 & 26 & 15 & 113 \\
\hline
\end{tabular}

\subsection{Conclusion}

Obviously, the change in the data sets used has contributed to a large decrease in the score by education between 2000 and 2002, i.e. from 1 to 0.82 . This decrease is even larger when the 3 educational segments, i.e. Lower education Economics, Intermediate education Agriculture and Breeding, and Intermediate education Environment, that account for $2 / 3$ of the loss are excluded. The score without these three educational segments is as low as 0.67. Regarding the qualitative characterisation, a slight improvement is observed too. The percentage of the educational segments with the right characterisation or almost the right characterisation increased from $78 \%$ to $82 \%$ between 2000 and 2002.

\section{Confrontation of demand and supply}

\subsection{Introduction}

The labour market perspectives for educational types depend on both demand and supply factors. The gap between expected demand and supply flows is at the heart of the indicator future labour market situation (IFLM). This indicator reflects the expected labour market perspectives by educational type. The indicator has been subject to an important change since the forecast of 1994. Until 1994, the forecast accounted for the ex ante demand and supply by educational groups and not for the (passive) substitution demand that arrises from shortages or surpluses in other educational groups. Since then, this substitution demand is accounted for. In this section 
using the school-leaver inquiries RUBS, HBO-Monitor and WO-Monitor, we evaluate the extent to which the predicted perspectives correspond to the realized situation for the various educational types.

\subsection{Labour market indicator}

To have a good insight in the labour market perspective of an educational group of workers two things are important. First, the current labour market situation of each educational type. Discrepancies observed in the current labour market may take time to disappear. If the base year is characterized by surpluses some workers may become unemployed or to accept jobs outside their own field. Since workers who have not found an appropriate job possibly remain searching for a job in their own professional field for a while, they will compete with school-leavers who just entered the labour market. The question is of course how long does this situation last. At some point in time, unemployed workers or people working in jobs outside their field become perceived as less suitable by employers and are no longer considered for jobs in their own occupational field.

The impact of the current labour market situation has been partially taken into account in the IFLM. On the supply side, besides the supply of school-leavers forecast, the number of short term unemployed persons with the corresponding education at the beginning of the forecast period is taken into account. There it is therefore assumed that persons who are unemployed for more than one year are no serious competition for school-leavers. The same reasoning applies to shortages of labour. If employers can not fill their vacancies with workers with the adequate skills, some of their vacancies will remain unfilled for a while. If vacancies are opened for a long period, employers will try to attract workers with another educational background or organize work differently. It can therefore be expected that the current discrepancies are especially important for the labour market perspective in the short run and less in the medium run. Therefore, the effect of a shortage at the beginning of the forecast period is not considered in the IFLM. This implies that vacancies are not considered in the demand side. On the demand side, the forecast for the expansion demand, the replacement demand and the substitution demand (only passive substitution is included) are considered.

The IFLM for each type of education is defined as follows: 


$$
I F L M=\frac{L_{97}+S S_{02-97}+U_{97}}{L_{97}+J O_{02-97}+S D_{02-97}}
$$

where $L_{97}$ is employment in 1997, $S S_{02-97}$ is the forecast school-leavers supply in the period $1997-2002, U_{97}$ is the short term unemployment level, $J O_{02-97}$ is the forecast of job openings (positive expansion demand and replacement demand) and $S D_{02-97}$ the forecast of substitution demand for the period $1997-2002$.

\subsection{Evaluation of the future labour market perspec- tives}

The IFLM gives an indication of the labour market perspectives of workers with the various educational backgrounds. As mentioned earlier, the current labour market situation is only partly considered in the determination of the IFLM, only short term unemployment is taken into consideration. The IFLM should be interpreted as a change in the labour market position of workers between the last observation year and the forecast year. A bad labour market position means that the labour market position will worsen compared to the last observation year. In the remaining of this section we will first evaluate the extent to which the IFLM is a good indicator of the changes in the labour market position of workers between 1997 and 2002. Discrepancies between demand for and supply of workers lead to a certain extent to unemployment or vacancies as noted earlier. If for a given educational type of workers, excess supply is observed, workers will have to adjust their jobs requirements. These workers will have to accept jobs below their level and with lower wages. In case of shortages, employers will have to improve their job offers in order to recruit the required workers. Moreover employers will probably have to recruit workers with other educational types and train them. To which extent discrepancies lead to unemployment or vacancies depends on the flexibility of the labour market and the substitution possibilities. To evaluate the forecast of the labour market perspective of workers we need to take into account this adjustment process that takes place in the labour market.

The first indicator of labour market discrepancies that we analyze is the so-called ex post gap. This gap is defined as the percentage of school-leavers that either work outside their own domain or are unemployed. ${ }^{11}$ The differ-

\footnotetext{
${ }^{11}$ Whether a worker works in her own domain is determined by the difference between
} 
ence between the ex ante discrepancies (the actual discrepancy) and the ex post gap depends on the flexibility of the labour market. If wages and other labour market characteristics do not adjust, then the ex post gap will be equal to the ex ante discrepancy. However, even in a situation of balanced demand and supply in the labour market, some workers will work outside their domain simply because they like jobs outside their domain better. This also means that in case of shortages the gap will be relatively small but will never be equal to 0 since part of the school-leavers will find it preferable to work outside their own domain. ${ }^{12}$

It might reasonably be expected that workers with different educational backgrounds will react differently to similar labour market discrepancies. For some educational segments, the labour market is more flexible and more substitution possibilities are available than for others. However, since our forecasting objective is to compare the discrepancy on the period 1997-2002 and not between two consecutive years, we compare between years and not between educational types. Therefore we have to assume that all educational segments react in the same way to labour market discrepancies.

From the school-leavers survey RUBS, higher education HBO-monitor and university WO-monitor, we have access to information regarding the labour market positions of the various educational types. These data sets are very useful for the evaluation of the IFLM. However, for some educational categories no information were reported so that the following analyses do not systematically have 113 educational types.

We first investigate the relationship between the change in the gap between 1997 and 2002 and the IFLM and between the level of the gap in 2002 and the IFLM. The following equations are estimated:

$$
\begin{aligned}
\Delta \operatorname{Gap}_{j} & =\alpha+\beta\left(\text { IFLM }_{j}-1\right)+e_{j} \\
\operatorname{Gap}_{j, 02} & =\alpha^{\prime}+\beta^{\prime}\left(\text { IFLM }_{j}-1\right)+e_{j}^{\prime}
\end{aligned}
$$

where $e_{j}$ is an error term satisfying the general assumptions and $j$ indicates the educational type, and Gap is the percentage of overeducated workers working outside their own educational field.

the employers' reported educational requirements (level and field) for the job and the worker's actual education (level and field).

${ }^{12}$ Note that the gap is related to shortages only. For an analysis of the effects of excess demand one would need employers data about the characteristics of their vacancies. This type of data is however not available at this level of aggregation. 
Equation 8 analyses the relationship between the change in the labour market situation between 1997 and 2002. A higher IFLM indicates that the labour market situation for school-leavers has worsened and therefore, the parameter $\beta$ should be positive. The constant term $\alpha$ indicates the mean change in the gap that does not depend on demand and supply factors. In equation 9 , we also expect $\beta$ to be positive and $\alpha$ can be interpreted as the mean of the 2002 gap.

Table 15: Relationship between forecasted and actual labour market position.

\begin{tabular}{l|rrrrr}
\hline \hline Variable & \multicolumn{1}{l}{$\alpha$} & $t-$ stat & & $\beta$ & \multicolumn{1}{l}{ 促 } \\
& & & & & \\
$\Delta$ Gap & -1.71 & -1.49 & & -6.65 & -0.80 \\
Gap $_{02}$ & 14.38 & 10.63 & ** & 14.57 & 1.47 \\
\hline
\end{tabular}

The estimation results are reported in Table 15. In equation 8 both estimates are not significant. This means that there is no significant relationship between forecasted labour market position and the actual change in the labour market position between 1997 and 2002. However, there is a positive relationship between the level of the gap in 2002 and the IFLM as indicated by the estimates for equation 9 .

The IFLM seems therefore to be an indicator of the absolute labour market position of an educational type. However, so far we only analyzed the ex post gap and did not look at the effects of various labour market characteristics. In the following part of the analysis, we take a closer look at the relationship between several labour market characteristics and the IFLM.

From the school-leaver surveys (RUBS, HBO monitor and WO monitor), the following labour market variables are available: unemployment rate, long term unemployment rate (percentage of school-leavers unemployed for more than 4 months), percentage school-leavers that find work outside their own domain, percentage that find work below their educational level, percentage with permanent contract, percentage with part time work and average (gross) monthly earnings (in 1,000 euros). For each of these characteristics the following equation is estimated:

$$
y_{j}^{k}=\alpha^{k}+\beta^{k}\left(I F L M_{j}-1\right)+e_{j}^{k}
$$


where $y_{j}^{k}$ is the labour market characteristic $k$ for educational type $j$.

Herewith, the IFLM is associated to the equilibrium situation, the $\alpha^{k}$ is interpreted as the mean of the associated characteristic variable, and the $\beta^{k}$ parameter indicates how the variable $k$ react to changes in the labour market perspective.

Table 16: Relationship between forecasted and actual labour market position.

\begin{tabular}{|c|c|c|c|c|c|c|}
\hline Variable & $\overline{\alpha \alpha}$ & $\overline{t-s t a t}$ & & 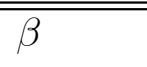 & $\bar{t} t-s t a t$ & \\
\hline Unemployment & 3.98 & 11.59 & $* *$ & 6.85 & 2.52 & $* *$ \\
\hline Long-term unemployment & 6.62 & 10.26 & $* *$ & 2.15 & 0.42 & \\
\hline Overeducated & 29.95 & 13.39 & $* *$ & 21.72 & 1.25 & \\
\hline Outside own field & 26.46 & 13.39 & $* *$ & 32.46 & 2.08 & $* *$ \\
\hline Part-time job & 27.05 & 9.93 & $* *$ & 42.10 & 1.96 & $* *$ \\
\hline Continuing track & 66.22 & 27.55 & $* *$ & -30.52 & -1.61 & \\
\hline Average wage & 1.70 & 20.61 & $* *$ & -1.95 & -3.00 & $* *$ \\
\hline
\end{tabular}

Table 16 reports the estimation results. ${ }^{13}$ As in previous evaluation studies, there is positive relationship between unemployment and IFLM. However, in contrast to previous results, this relationship does rely on a significant estimate. Although, long term unemployment does not seem to be significantly affected by the labour market perspective. Only four of the 8 indicators depend significantly on the IFLM: Unemployment, working outside its own field, part time work and average wage. For the first three indicators mentioned there is a positive relationship with the labour market perspective. For the last indicator there is a negative relationship, a high IFLM, i.e. a bad labour market perspective for a given education, will decrease the average wage of school-leavers with this education.

To determine how well did the IFLM indicator forecast the future labour market situation, we need to take all these indicators into account simultaneously. The equation we want to estimate is the following:

\footnotetext{
${ }^{13}$ Since in each equation the expanatory variables are the same, the OLS results presented here are equivalent to simultanous estimates as derived from Seemingly Unrelated Regression.
} 


$$
I F L M_{j}=\alpha_{02}+\sum_{k} \beta_{02}^{k} y_{j, 02}^{k}+e_{j}
$$

where $y_{j, 02}^{k}$ is the labour market characteristic $k$ for educational type $j$ in 2002 expressed in deviation from the educational level mean percentage.

We are herewith not so much interested in the causality but rather in the extent to which each indicator explains the IFLM. Using the estimates of equation 11, we derive the IFLM realizations as: $I \widehat{F L M} M_{j}=\widehat{\alpha}_{02}+\sum_{k} \widehat{\beta}_{02}^{k} y_{j, 02}^{k}{ }^{14}$ The estimation provides also a score for the labour market perspective forecast. Indeed, the score of the forecast is simply equal to $1-\bar{R}^{2}$ where $\bar{R}^{2}$ is the adjusted $R^{2}$ of the regression. The IFLM score for the period 1997-2002 is equal to $1-0.14=0.86$. This score is in the range of magnitude observed in previous evaluation (1994, 0.80, 1998, 0.86 and 2000, 0.80).

Equation 11 indicates that roughly $20 \%$ (the unadjusted $R^{2}=0.20$ ) of the variation in the IFLM across education is explained by variation in the levels of the various labour market characteristics $k$ across educational types. Although this percentage of variation in IFLM explained by labour market characteristics seems to be stable in the various evaluations, this does not mean that one could just take the 2002 estimates of equation 11 and forecast the IFLM for 2006 using forecast of labour market characteristics $y_{j, 06}^{k}$ for 2006. Indeed, the IFLM forecast as derived from forecast of expansion demand, replacement demand and supply take into account complex structural changes in the labour market such as technical changes (in expansion demand) not accounted for when extrapolating trends from equation 11 . To illustrate the importance of these structural changes in the IFLM forecast, I propose to decompose the changes in the IFLM between two forecasting periods, say 2002 and 1998, into structural changes and changes in the labour market characteristics as follows:

\footnotetext{
${ }^{14}$ Coefficients for 2002 (respectively 1998) are: constant $=0.93$ (1.03), long-term unemployment $=-0.14(0.04)$, unemployement $=0.64(0.014)$, part-time $=0.09(0.45)$, permanent contract $=-0.37(-0.09)$, own field $=0.02(-0.43)$, overeducated $=0.03$ $(-0.17)$ and average wage $=0.77$. Note that in 1998 , the percentage of workers earning low wages was used instead of average wage. The effect of this coefficient will therefore be "shut off " (coefficient in 1998 set equal to coefficient in 2002) in the following analysis.
} 


$$
\begin{aligned}
\Delta I \widehat{F L} M_{j, 02-98}= & \left(\Delta \widehat{\alpha}_{02-98}+\sum_{k} \Delta \widehat{\beta}_{02-98}^{k} y_{j, 98}^{k}\right)+ \\
& \left(\widehat{\alpha}_{98}+\sum_{k} \widehat{\beta}_{98}^{k} \Delta y_{j, 02-98}^{k}\right)
\end{aligned}
$$

where $\left(\Delta \alpha_{02-98}+\sum_{k} \Delta \beta_{02-98}^{k} y_{j, 02}^{k}\right)$ represent the part of changes in IFLM due to changes in the structural parameters $\alpha$ and $\beta$ 's and $\left(\alpha_{98}+\sum_{k} \beta_{98}^{k} \Delta y_{j, 98}^{k}\right)$ represents the part of changes in IFLM due to changes in the labour market characteristics variables. Note that we assume $\widehat{\beta}_{02}^{k}=\widehat{\beta}_{98}^{k}$ for $k$ is average wage, since no estimate is available for 1998.

Since educational classification has changed since the previous evaluation, I use the parameter estimates for 1998 and labour market characteristics variables observed in 1998 but with the new educational classification to generate the $I \widehat{F L} M_{j, 98}$. I then compute the left hand side of equation 12, $\triangle I \widehat{F L M} M_{j, 02-98}=I \widehat{F L M} M_{j, 02}-I \widehat{F L M} M_{j, 98}$ and both components on of the right hand side, i.e. $\left(\Delta \widehat{\alpha}_{02-98}+\sum_{k} \Delta \widehat{\beta}_{02-98}^{k} y_{j, 98}^{k}\right)$ and $\left(\widehat{\alpha}_{98}+\sum_{k} \widehat{\beta}_{98}^{k} \Delta y_{j, 02-98}^{k}\right)$.

Under the null hypothesis that changes in IFLM between two periods are merely due to changes in the labour market characteristics $y^{k}$, the first term should not explain a significant part of the variance in IFLM. However, when changes in IFLM capture structural changes in the labour market, the first term in the right hand side of equation 12 will explain a significant part of changes in IFLM. To test this null hypothesis, I first regress $\triangle I \widehat{F L M} M_{j, 02-98}$ on $\left(\widehat{\alpha}_{98}+\sum_{k} \widehat{\beta}_{98}^{k} \Delta y_{j, 02-98}^{k}\right)$ only and then add $\left(\Delta \widehat{\alpha}_{02-98}+\sum_{k} \Delta \widehat{\beta}_{02-98}^{k} y_{j, 98}^{k}\right)$ to the regressors. The percentage of variation explained by changes in the labour market variables only is $38 \%$ as indicated by the $R^{2}$ of the first restricted regression and increased significantly $\left(F_{1 ; 62}-\right.$ statistic $=202.95$, significant at $1 \%$ ) to $85 \%$ when both components are included.

This analysis clearly indicates that even though the labour market indicator forecast for year $t$ are significantly correlated with the observed labour market situation in year $t$ (roughly $20 \%$ of the variation in IFLM is explained by variation in labour market variables such as unemployment, wages etc. as indicated by the $R^{2}$ ), the forecast take into account not only changes in 
unemployment, wages etc. but also account for more complex structural changes captured by changes in the structural parameters of equation 11 . Hence, in 1997, one would not have achieved a score of $0.86\left(1-\bar{R}^{2}\right)$ when forecasting future labour market situation for 2002 by "simply" forecasting the percentage unemployed, working part-time etc. for 2002 and using the 1997 parameter estimates of the structural relationship described in equation 11.

\section{Qualitative evaluation}

The realizations of the IFLM derived from the estimation of equation 11 allow us to evaluate as in the other sections of this report the qualitative aspect of the forecast of IFLM by educational type. We assign to each forecast a qualitative characterisation. The classification of characterisations is defined as follows: Very good: IFLM $\leq 0.85,0.85<I F L M \leq 1$ good, $1<I F L M \leq 1.05$ average, $1.05<I F L M \leq 1.15$ bad and $I F L M>1.15$ very bad.

Table 17: Qualitative evaluation of labour market indicator by education.

\begin{tabular}{lrrrrrr}
\hline \hline & & Realization & & \\
Forecast & Very good & Good & Average & Bad & Very bad & Total \\
Very good & 3 & 6 & 0 & 0 & 0 & 9 \\
Good & 0 & 38 & 6 & 0 & 0 & 44 \\
Average & 0 & 5 & 2 & 0 & 0 & 7 \\
Bad & 0 & 3 & 1 & 0 & 0 & 4 \\
Very bad & 0 & 1 & 1 & 1 & 0 & 3 \\
Total & 3 & 53 & 10 & 1 & 0 & 67 \\
\hline
\end{tabular}

Table 17 indicates the extent to which the characterisation of the forecast corresponds with the characterisation of the realizations by educational type. Note that data where available for 67 categories only. It is also important to note that in equation 11 is estimated based on the forecast of IFLM and therefore assuming that the forecasting errors have expected mean equal to 0 . Since both the forecast and the realizations are measured with errors, the eventual noise in the type of the IFLM comes about not only because of forecasting errors but also because of discrepancies in the measurement errors between forecast and realizations. 
The table indicates that the characterisation assigned to each education has been relatively accurate. Indeed, 43 out of 67 educational types, that is $64 \%$, have been assigned the right characterisation. In $1994,45 \%$ of the educational groups was assigned the correct characterisation and in 1998 this percentage had increased to $52 \%$. Moreover, 19 educational types have been assigned a characterisation just one category away from the right category. This means that $93 \%$ of all educational types has the right characterisation or almost. Note that $71 \%$ of educational types with less than 10,000 workers had the right characterisation and all had the right characterisation or almost. There is no systematic relationship between employment size and wrong characterisation.

\section{Qualitative evaluation of IFRP}

For the 1997-2002 forecast for the first time the indicator of future recruitment problems (IFRP) was introduced. This indicator takes into account the fact that in periods where employment shrinks for some educational types, the total demand may be somewhat different of the number of job openings for new entrants. Indeed, employers can choose instead of firing workers to hold employment level constant and cancel future hires. This type of behavior may be intensively observed in periods of tight labour market for certain types of education.

The IFRP is defined as follows:

$$
I F R P=\frac{L_{97}+S S_{02-97}+U_{97}}{L_{97}+E D_{02-97}+R D_{02-97}+S D_{02-97}}
$$

where $L_{97}$ is employment in 1997, $S S_{02-97}$ is the forecast school-leavers supply in the period 1997-2002, $U_{97}$ is the short term unemployment level, $E D_{02-97}$ is the forecast expansion demand, $R D_{02-97}$ the forecast replacement demand and $S D_{02-97}$ the forecast substitution demand for the period $1997-2002$.

The classification of characterisations is defined as follows: Very large $I F R P \leq 0.85,0.85<I F R P \leq 1$ large, $1<$ IF RP $\leq 1.05$ average, $1.05<$ $I F R P \leq 1.15$ small and $I F R P>1.15$ very small.

Table 18 indicates the extent to which the characterisation of the forecast corresponds with the characterisation of the realizations by educational type 42 out of 67 educational types, that is $63 \%$, have been assigned the right characterisation. Moreover, 18 educational groups have been assigned a characterisation just one category away from the right category. This means that $90 \%$ of all educational types has the right characterisation or almost. 
Table 18: Qualitative evaluation of labour market indicator, IFRP, by education.

\begin{tabular}{lrrrrrr}
\hline \hline & & Realization & & \\
Forecast & Very large & Large & Average & Small & Very Small & Total \\
Very large & 3 & 5 & 0 & 0 & 0 & 8 \\
Large & 1 & 36 & 4 & 1 & 0 & 42 \\
Average & 0 & 4 & 3 & 0 & 0 & 7 \\
Small & 0 & 3 & 2 & 0 & 0 & 5 \\
Very small & 0 & 2 & 2 & 1 & 0 & 5 \\
Total & 4 & 50 & 11 & 2 & 0 & 67 \\
\hline
\end{tabular}

\subsection{Conclusion}

As in previous evaluation studies, there is positive relationship between unemployment and IFLM. However, in contrast to previous results, this relationship does rely on a significant estimate. Although, long term unemployment does not seem to be significantly affected by the labour market perspective. Only four of the 8 indicators depend significantly on the IFLM: Unemployment, working outside its own field, part time work and average wage. For the first three indicators mentioned there is a positive relationship with the labour market perspective. For the last there is a negative relationship, a high IFLM, i.e. a bad labour market perspective for a given education, will decrease the average wage of school-leavers with this education.

The IFLM score for the period $1997-2002$ is equal to $1-0.14=0.86$. This score is in the range of magnitude observed in previous evaluation (1994, 0.8, 1998, 0.86 and 2000, 0.80). Moreover, 93\% of all educational types has the right characterisation or almost the right characterisation.

\section{Conclusion}

In this report, we evaluated the forecast of the labour market situation by education and occupation for the period 1997-2002. To conclude this evaluation, we propose to summarize the main findings by comparing summary findings for the expansion demand, replacement demand, job openings, supply and future labour market indicators of this report with those previously 
Table 19: Trend in average loss and score by occupation and education.

\begin{tabular}{|c|c|c|c|c|c|}
\hline Variable & $\begin{array}{r}\text { Average Loss } \\
2002\end{array}$ & $\begin{array}{r}\text { (Relative) } \\
2000\end{array}$ & 1998 & 1994 & 1992 \\
\hline \multicolumn{6}{|l|}{ Occupation } \\
\hline Expansion demand & 0.0399 & 0.0214 & 0.0229 & 0.0344 & 0.0727 \\
\hline Replacement demand & 0.0024 & 0.0026 & 0.0019 & 0.0022 & 0.0180 \\
\hline Job openings & 0.0291 & 0.0136 & 0.0154 & 0.0211 & 0.0623 \\
\hline $\begin{array}{l}\text { Education } \\
\text { Replacement demand } \\
\text { Supply }\end{array}$ & $\begin{array}{l}0.0032 \\
0.0346\end{array}$ & $\begin{array}{l}0.0020 \\
0.0146\end{array}$ & $\begin{array}{r}0.0021 \\
-\end{array}$ & $\begin{array}{l}0.0022 \\
0.0585\end{array}$ & $\begin{array}{r}0.0039 \\
-\end{array}$ \\
\hline Variable & Score & $\begin{array}{r}\text { (Relative) } \\
2000\end{array}$ & 1998 & 1994 & 1992 \\
\hline \multicolumn{6}{|l|}{ Occupation } \\
\hline Expansion demand & 0.97 & 0.77 & 0.83 & 0.57 & 0.95 \\
\hline Replacement demand & 1.10 & 1.23 & 1.08 & 1.39 & 1.00 \\
\hline Job openings & 0.91 & 0.77 & 0.94 & 0.45 & - \\
\hline \multicolumn{6}{|l|}{ Education } \\
\hline Replacement demand & 0.91 & 1.37 & 2.03 & 2.26 & 0.96 \\
\hline Supply & 0.88 & 1.00 & - & - & - \\
\hline IFLM & 0.86 & 0.80 & 0.86 & 0.80 & 0.91 \\
\hline
\end{tabular}

obtained in the evaluation of the forecast for the periods 1995-2000, 19931998, 1989-1994 and 1987-1992.

Table 19 gives a trend overview of the evaluation results, i.e. the average loss and the score, obtained at the sector level, occupational level and educational level for expansion demand, replacement demand, job opening, supply and labour market indicator. As in previous evaluations, the largest average loss was observed for expansion demand by occupational class. The average loss for expansion demand by occupational class, however, has increased for the first time breaking the downward trend recorded since the first evaluation. As noticed earlier in this report, this may be mainly due to changes in 
the sector classification and the further disaggregation of the occupational classification from 93 to 127 groups. Regarding replacement demand forecast by occupational class, the average loss is low and seems to be rather stable since the second evaluation in 1994. It is worth noting that even though the score for replacement demand by occupational class has been going up and down ever since the beginning of the forecast, the magnitude of these swings is decreasing indicating stability of the forecast quality. However, the score remains larger than one stemming for further improvements of the methodology.

Table 20: Trend in qualitative characterisation (relative) by occupation and education.

\begin{tabular}{|c|c|c|c|c|c|}
\hline Variable & $\begin{array}{r}\text { Right category } \\
2002\end{array}$ & 2000 & 1998 & 1994 & 1992 \\
\hline \multicolumn{6}{|l|}{ Occupation } \\
\hline Expansion demand & 18 & 42 & 40 & 43 & 24 \\
\hline Replacement demand & 34 & 45 & 52 & 32 & 29 \\
\hline Job openings & 31 & 37 & 29 & 44 & 33 \\
\hline \multicolumn{6}{|l|}{ Education } \\
\hline Replacement demand & 36 & 25 & 34 & 32 & 26 \\
\hline Supply & 35 & 33 & - & 67 & - \\
\hline IFLM & 64 & 38 & 52 & 45 & 30 \\
\hline \multirow[t]{2}{*}{ Variable } & Almost right & & & & \\
\hline & 2002 & 2000 & 1998 & 1994 & 1992 \\
\hline \multicolumn{6}{|l|}{ Occupation } \\
\hline Expansion demand & 61 & 68 & 66 & 85 & 61 \\
\hline Replacement demand & 80 & 76 & 73 & 76 & 62 \\
\hline Job openings & 79 & 76 & 60 & 84 & 63 \\
\hline \multicolumn{6}{|l|}{ Education } \\
\hline Replacement demand & 84 & 57 & 77 & 60 & 47 \\
\hline Supply & 82 & 78 & - & 98 & - \\
\hline IFLM & 93 & 75 & 83 & 90 & 67 \\
\hline
\end{tabular}


The most striking result is the significant decrease in the score of replacement demand by education observed since 1994, decrease from 2.26 to 0.91 . Even more remarkable is that for the first time this score is lower than 1 indicating that the random coefficient model has improved significantly the quality of the forecast and outperform the Same As Before forecast.

Job openings is composed of positive expansion demand and replacement demand. Since the forecast of both components are empirically negatively correlated, the average loss obtained for job openings is lower than the sum of average loss of both components. The average loss of the 2002 forecast is however strongly influenced by expansion demand and therefore relatively larger than in previous evaluations. The score, however, though increasing, remains lower than unity.

Evaluation of supply has not always been possible so that we cannot derive trends in the forecast quality. Note however, that the score obtained for the forecast of supply is 0.88 which indicates a good general quality of the forecast.

The future indicator of the labour market, i.e. IFLM, is a good indicator of the labour market situation in the forecast year. In educational types for which a bad labour market perspective was forecast, school-leavers have had to accept jobs outside their educational field, working part time and faced higher risk to become temporarily unemployed. As indicated in Table 20, the IFLM gives for $93 \%$ of all educational types a good forecast of the labour market perspective which is the largest figure ever achieved.

This report indicates that the labour market forecast to 2002 have been rather accurate. Few changes in the methodology have taken place since 2000 and improvements in the forecast quality have been observed notably for replacement demand by educational type, the labour market indicator and the forecast of supply. This may imply that the forecast by education have improved due to a better clustering of education (see Heijke et al. 2003). Although the number of educational types increased from 83 to 113, these types of education may be more homogeneous. ${ }^{15}$ Moreover, the improvement in the forecast of supply may be due to the use of better input data.

However, several aspects of the forecast have worsen or at least not gotten better. The forecast of expansion demand by occupational groups seems

\footnotetext{
${ }^{15}$ Note that errors in replacement demand forecast for small educational types are not significantly larger in percentage than in larger educational types (the scale parameter is not significantly different from 1). The increased number of educational types therefore did not lead to less accurate forecast in small educational types.
} 
to have suffered tremendously from the changes in the sector classification leading to a score just below unity. Another possible cause for the worsening of the expansion demand forecast could be the increase of the number of occupational classes distinguished. Indeed, the size of the occupational class (scale effect) has a significant impact on the variance of the errors of the forecast and forecast of expansion demand in small occupational classes are worse (in percentages) than in large occupational classes. Moreover, because this scale effect has increased in magnitude (decrease of the scale parameter from 0.8 in 2000 to 0.5 in 2002) compared with the previous evaluation, this is a plausible, though partial, explanation. Replacement demand by occupational class is improving a bit but does not achieve satisfactory standards yet. Improving results for replacement demand by education following the implementation of the random coefficient model are encouraging though, and leaves hope that the random coefficient model will improve replacement demand by occupational class soon too.

\section{Nederlandse samenvatting}

In dit rapport worden de voorspellingen geëvalueerd van de arbeidsmarktsituatie naar opleiding en beroep voor de periode 1997-1992. Uitgangspunt bij de beoordeling van de prognoses is dat deze geschikt moeten zijn voor de studie- en beroepskeuze. Het uitgangspunt voor de gehanteerde beoordelingsmethode vormen de vragen die volgens Granger en Newbold (1986) bij een objectieve evaluatie beantwoord moeten worden:

1. Zijn de voorspellingen beter dan de beschikbare alternatieven?

2. Hoe 'goed' zijn de voorspellingen?

3. Kan de methode waarmee de voorspellingen zijn opgesteld zodanig aangepast worden dat een verbeterde voorspelkwaliteit verwacht mag worden?

Het gehanteerde evaluatiecriterium geeft voornamelijk een waardering voor het gemiddeld 'verlies' dat ontstaat door voorspelfouten. Het gemiddelde verlies geeft een schatting van de spreiding van de voorspellingen rond de realisatie. Daarnaast wordt een 'score-definitie' gebruikt waarmee prognoses worden vergeleken met een referentieprognose. Als de voorspelkwaliteit 
van een prognose beter is dan de referentieprognose, dan zal de score een waarde aannemen die kleiner is dan één. Een score groter dan één duidt op een prognose die slechter is dan de referentieprognose.

De belangrijkste evaluatieresultaten zijn samengevat in de tabellen 19 en 20, waarin een vergelijking wordt gemaakt tussen de resultaten voor de uitbreidingsvraag, de vervangingsvraag, het aantal baanopeningen, het aanbod van schoolverlaters en de toekomstige arbeidsmarktindicatoren in dit rapport en de resultaten die eerder zijn gevonden in de prognoses voor de perioden 1995-2000, 1993-1998, 1989-1994 en 1987-1992.

De uitbreidingsvraag naar beroep kent het grootste gemiddelde verlies, net zoals het geval was bij de vorige evaluaties. Het gemiddelde verlies voor de uitbreidingsvraag naar beroep is echter voor het eerst gestegen, waarmee de neerwaartse trend sinds de eerste evaluatie wordt doorbroken. Een mogelijke oorzaak hiervoor zijn de veranderingen in de sectorclassificatie en de verdere desaggregratie van de beroepenclassificatie van 93 naar 127 groepen.

Voor de vervangingsvraagvoorspelling naar beroep geldt dat het gemiddelde verlies laag en redelijk stabiel is sinds de tweede evaluatie in 1994. Daarnaast blijkt dat, ondanks de volatiliteit van de score voor de vervangingsvraag naar beroep, de grootte van de schommelingen in de score zijn gedaald. De score blijft echter groter dan één. Dit betekent dat verdere verbeteringen in de methodologie noodzakelijk zijn.

Het meest opvallende resultaat is dat de score voor de vervangingsvraag naar opleiding sinds 1994 gedaald is van 2,26 naar 0,91. Hiermee ligt de score voor het eerst onder de waarde één, wat mogelijk een indicatie geeft voor dat het random-coëfficiënten-model significant heeft bijgedragen bij het verbeteren van de kwaliteit van de voorspelling.

Het aantal baanopeningen is samengesteld uit de positieve uitbreidingsvraag en de vervangingsvraag. Aangezien de voorspelling van beide componenten empirisch negatief gecorreleerd zijn, is het gemiddelde verlies voor het aantal baanopeningen kleiner dan de som van het gemiddelde verlies van beide componenten. Echter het gemiddelde verlies in de evaluatie voor 2002 is sterk beïnvloed door de uitbreidingsvraag en is derhalve relatief groter dan in de voorgaande evaluaties. De score voor het aantal baanopeningen blijft ondanks een stijgende trend onder de kritieke waarde één.

Evaluatie van het aanbod was niet altijd mogelijk, wat de analyse van mogelijke trends in de voorspelkwaliteit ernstig bemoeilijkt. De voorspelling van het aanbod lijkt echter een goede kwaliteit te hebben, aangezien de score 0,88 bedraagt. 
Het laatste evaluatieresultaat heeft betrekking op de indicator voor de toekomstige situatie op de arbeidsmarkt (ITA). De ITA is een goede indicator voor de arbeidsmarktsituatie in het jaar waarvoor een prognose wordt gemaakt. Voor opleidingstypen waarvoor een slecht arbeidsmarktperspectief was voorspeld, moesten schoolverlaters banen buiten hun vakrichting accepteren, moesten zij parttime banen accepteren en werden zij geconfronteerd met een hoger werkloosheidsrisico. De ITA geeft voor $93 \%$ van alle opleidingstypen een redelijk goede voorspelling van het arbeidsmarktperspectief (precies of bijna goed).

Het rapport geeft weer dat de arbeidsmarktprognoses tot 2002 redelijk accuraat zijn. Er zijn grote verbeteringen zichtbaar in de voorspelkwaliteit van de vervangingsvraag naar opleiding, de arbeidsmarktindicator ITA en het aanbod. Deze verbeteringen kunnen een gevolg zijn van een andere clustering van beroepen en opleidingen, alsmede van enkele kleine methodologische veranderingen. Mogelijk zijn de voorspellingen naar opleiding verbeterd door een betere clustering van opleidingen (zie Heijke e.a., 2003). Ondanks dat het aantal opleidingstypen steeg van 83 naar 113, kunnen de opleidingstypen meer homogeen geworden zijn. Daarnaast kan de verbetering in de voorspelling tot stand gekomen zijn door een verbeterd gebruik van input data voor de prognoses van het aanbod van schoolverlaters op de arbeidsmarkt.

Enkele aspecten van de prognoses lijken echter te zijn verslechterd of niet te zijn verbeterd. De prognoses van de uitbreidingsvraag naar beroep lijken last te hebben van de veranderingen in de sectorclassificatie. Dit leidt tot een score die net onder één ligt. Daarnaast draagt mogelijk ook de stijging in het aantal onderscheiden beroepsgroepen bij aan de slechtere kwaliteit van de prognose. De vervangingsvraag naar beroep verbetert licht maar voldoet nog niet aan de gewenste standaard. Echter de verbetering in de resultaten voor de vervangingsvraag naar opleiding stemt ons positief, waardoor de hoop bestaat dat het random-coëfficiënten-model op termijn eveneens voor verbetering zal zorgen voor de vervangingsvraag naar beroep.

\section{References}

Beekman, Th.B.J., R.J.P. Dekker, A. de Grip, and J.A.M. Heijke (1989), An Explanation of the Educational Structure of Occupations, ROA-W-1989/3E, Maastricht (also published in Labour 5-3, 1992 pp. 151-163)

Borghans, L. (1991), De arbeidsmarkt en de invloed van voorspellingen, 
Economische Statistische Berichten, 76-3833, pp. 1113-1116.

Borghans, L. (1992), A Histo-Topographic Map of the Dutch University Studies, ROA-W-1992/5E, Maastricht.

Borghans, L. (1993), Educational Choice and Labour Market Information, thesis, University of Limburg, Maastricht.

Borghans, L., and J.A.M. Heijke (1996), Forecasting the Educational Structure of Occupations: A Manpower Requirements Approach with Substitution, Labour, vol. 10 (1), pp. 151-92.

Borghans, L., and J.A.M. Heijke (1994), Een random-coëfficiëntenmodel voor het voorspellen van de beroepenstructuur van bedrijfstakken, ROA-W1994/1.

Borghans, L., A. de Grip, J. Delmee, J. van Loo and A. Matheeuwsen (1997), Methodiek arbeidsmarktprognoses en indicatoren 1997-2002, ROAW-1997/6.

Bosworth, D.L., G.J. Evans, and R.M. Lindley (1974), Mechanic Manpower Models, in: J.S. Wabe (ed), Problems in Manpower Forecasting, Westmead, pp. 61-84.

Clements, M.P. (1995), Rationality and the role of judgement in macroeconomic forecasting, Economic Journal, Vol. 105, pp. 410-420.

Clements, M.P., and D.H. Hendry (1993), Towards a Theory of Forecasting, unpublished paper.

CPB(1993), Athena; Een bedrijfstakkenmodel voor de Nederlandseleconomie, CPB, Den Haag.

Cörvers, F. B.J. Diephuis, A. Dupuy en P. van Eijs (2004), Evaluatie arbeidsmarktprognoses naar opleiding en beroep tot 2000, ROA-R-2004/8, Maastricht.

De Grip, A., L. Borghans and W. Smits (1998), Future Developments in the Job Level and Domain of High-skilled Workers, in: H. Heijke, L. Borghans (eds.), Towards a Transparent Labour Market for Educational Decisions, Ashgate, Aldershot/Brookfield USA/Singapore/Sydney, pp. 21-56.

De Grip, A., L.F.M. Groot, and J.A.M. Heijke (1987), Clustering Occupational Classes by Educational Structure, ROA-W-1987/2E, Maastricht (also published as: Defining Occupational Groupings by Educational Structure, Environment and Planning A, 1991, vol. 23 pp. 59-85)

De Grip, A., and J.A.M. Heijke (1991), Flexibiliteit versus produktiviteit, Onderzoek van Onderwijs, vol. 20-1, pp. 6-8.

De Grip, A., J.A.M. Heijke, and H. Berendsen (1991), Eerste evaluatie informatiesysteem onderwijs-arbeidsmarkt, ROA-R-1991/1, Maastricht. 
De Grip, A., J.A.M. Heijke, J.W. van Dam, R.J.P. Dekker, and M.H. Wieling (1988), Aanvulling arbeidsmarktmodule I-See project (wetenschappelijk onderwijs), ROA-R-1988/2, Maastricht.

De Grip, A., J.A.M. Heijke, and R.J.P. Dekker (1989), The Labour Market by Education and Occupation to 1992, ROA-R-1989/8E, Maastricht.

De Grip, A., J.A.M. Heijke, R.J.P. Dekker, Th.B.J. Beekman, and H.M.M. Peeters (1989), De arbeidsmarktperspectieven van beroepsklassen en opleidingstypen in 1992: rapportage I-See!, ROA-R-1989/7, Maastricht.

De Grip, A., J.A.M. Heijke, R.J.P. Dekker, and L.F.M. Groot (1987a), Labour Market Prospects for Occupations and Academic Studies in 1992, ROA-W-1987/1E, Maastricht.

De Grip, A., J.A.M. Heijke, R.J.P. Dekker, L.F.M. Groot, and L.A. Vos (1987b), De arbeidsmarktperspectieven van studierichtingen in het wetenschappelijk onderwijs, Arbeidsmarktmodule I-See project, ROA-R-1987/3, Maastricht.

De Grip, A., J.A.M. Heijke, and L.A. Vos (1987), Inventariserend onderzoek arbeidsmarktmodule I-See project, ROA-R-1987/1, Maastricht.

De Grip, A., and E.J.T.A. Willems (1992), De vervangingsvraag naar beroepsklasse tot 2000, OSA-W 96, Den Haag.

Dekker, R.J.P., and A. de Grip, Vergelijking tussen de CBS- en de ROAberoepenclassificatie, ROA-W-1992/3, Maastricht.

Dekker, R.J.P., A. de Grip, Th.B.J. Beekman, P.J.E. van de Loo, M.H. Wieling, and E.J.T.A. Willems (1990), Rapportage I-See! 1990, ROA-R1990/6, Maastricht.

Dekker, R.J.P., A. de Grip, H. Berendsen, M.H. Wieling, and E.J.T.A. Willems (1992), Methodiek en structuur arbeidsmarktmodule I-See! 1991, ROA-W-1992/1, Maastricht.

Dekker, R.J.P., A. de Grip, L. Borghans, A.G.M. Matheeuwsen, M.H. Wieling, and E.J.T.A. Willems (1993), Methodiek van het informatiesysteem onderwijs-arbeidsmarkt 1993, ROA-W-1993/3, Maastricht.

Evans, G.J., and R.M. Lindley (1973), The use of RAS and Related Models in Manpower Forecasting, Economics of Planning, 13-12, pp. 5373.

Granger, C.W.J., and Newbold (1986), Forecasting Economic Time Series, Academic Press Inc., Orlando.

Heijke, H., A. Matheeuwsen and E. Willems (2003), Clustering Educational Categories in a Heterogeneous Labour Market, Education Economics, Vol. 11, pp. 89-108. 
Matheeuwsen, A. and A. de Grip (1997), De doorstroom van het reguliere naar het niet-reguliere onderwijs, ROA-W-1997/4.

Ministerie van Onderwijs, Cultuur en Wetenschappen (1997), Referentieraming 1997, Zoetermeer.

ROA (1997), De arbeidsmarkt naar opleiding en beroep en beroep tot 2002, ROA-R-1997/7, Maastricht.

Smits, W. and B. Diephuis (2001), Evaluatie arbeidsmarktprognoses naar opleiding en beroep tot 1998, ROA-R-2001/2, Maastricht.

Theil, H. (1958), Economic forecasts and policy. Amsterdam.

Van der Velden, R., and L. Borghans (1993), Competition on the Labour Market. An Analysis of the Position of Types of Training', ROA-RM-1993/5E, Maastricht.

Van Eijs, P. (1993), The Manpower Requirements Approach, Background and Methodology, ROA-RM-1993/3E, Maastricht.

Van Eijs, P., and L. Borghans (1997), The use of RAS in manpower forecasting: a microeconomic approach, in: Economic Modelling, Elsevier Science, B.V., 1996, pp. 257-287.

Vlasblom, J.D., B.J. Diephuis, S. Dijksman, P. Marey (2000), Ontwikkelingen op de arbeidsmarkt in 2001, ROA-R-2000/10, Maastricht.

Wieling, M.H., A. de Grip, and E.J.T.A. Willems (1990), Een systematische kwalitatieve typering van arbeidsmarktinformatie, ROA-W-1990/8, Maastricht also published as 'Forecasting Replacement Demand by Occupation and Education'. International Journal of Forecasting 9, 1993, pp. 173-185).

Wieling, M. and L. Borghans (2001), Discrepancies between Supply and Demand and Adjustment Processes in the Labour Market, Labour, Vol. 15 (1), pp.33-56.

Wilson, R. (1994), Modelling and Forecasting the Structure of Employment in the United Kingdom, in: H. Heijke (ed), Forecasting the Labour Market by Occupation and Education, Boston, pp. 9-35.

Willems, E.J.T.A., A. de Grip (1993), Forecasting Replacement Demand by Occupation and Education, in: International Journal of Forecasting, vol. 9, pp. 173-185.

Willems, E.J.T.A. (1996), Manpower Forecasting and Modelling Replacement Demand: an Overview, ROA-W-1996/4E. 
Appendix 
Table 21

Forecasting quality of expansion demand by occupational groups

\begin{tabular}{|c|c|c|c|c|c|}
\hline Occupation & $\begin{array}{r}\text { Employment } \\
1997\end{array}$ & $\begin{array}{r}\text { Forecast } \\
2002\end{array}$ & $\begin{array}{r}\text { Employment } \\
2002\end{array}$ & $\begin{array}{r}\text { Forecasting } \\
\text { error }\end{array}$ & Loss \\
\hline Primary school teachers & 132000 & 134400 & 153000 & 18800 & 0.015 \\
\hline Teachers of science, medical, hotel and catering subjects (2nd and 3rd degree) & 19000 & 17200 & 24000 & 6400 & 0.074 \\
\hline Teachers of science, medical, hotel and catering subjects ( 1 st degree and UE) & 14000 & 16100 & 13000 & -3100 & 0.057 \\
\hline Agricultural and technical teachers (2nd and 3rd degree) & 15000 & 15100 & 16000 & 1300 & 0.006 \\
\hline Agricultural and technical teachers (1 st degree and UE) & & 3200 & 6000 & 2600 & 0.201 \\
\hline Teachers of economic and administrative subjects (2nd and 3rd degree) & $700 \overline{0}$ & 6100 & 16000 & 10100 & 0.389 \\
\hline Teachers of economic and administrative subjects ( 1 st degree and UE) & 10000 & 10700 & 9000 & -2200 & 0.067 \\
\hline Language and arts teachers & 34000 & 32200 & 45000 & 13100 & 0.084 \\
\hline Language teachers ( 1 st degree and UE) & 23000 & 28300 & 23000 & -5300 & 0.053 \\
\hline Teachers of social, psychological subjects (2nd and 3rd degree) & 10000 & 9600 & 15000 & 5900 & 0.145 \\
\hline Teachers of social subjects ( 1 st degree and UE) & 7000 & 6400 & 7000 & 900 & 0.015 \\
\hline 2nd and 3rd degree teachers no specialisation & 11000 & 11400 & 10000 & -1700 & 0.031 \\
\hline 1 st degree teachers, no specialisation & & 3800 & & -700 & 0.051 \\
\hline Pedagogical staff & $800 \overline{0}$ & 10700 & $1000 \overline{0}$ & -400 & 0.002 \\
\hline Educational scientists and pedagogues & 18000 & 21400 & 22000 & 600 & 0.001 \\
\hline Driving instructors & 7000 & 6800 & 8000 & 1100 & 0.019 \\
\hline Swimming instructors & & 4000 & & -4000 & 0.000 \\
\hline Sports instructors & $800 \overline{0}$ & 8600 & $1200 \overline{0}$ & 3400 & 0.080 \\
\hline Interpreters, translators and writers & 8000 & 9100 & 13000 & 4300 & 0.103 \\
\hline Library assistants & 22000 & 21300 & 21000 & 0 & 0.000 \\
\hline Librarians & 10000 & 10400 & 6000 & -4500 & 0.582 \\
\hline Graphic designers & 8000 & 10800 & 11000 & -200 & 0.000 \\
\hline Artists & 46000 & 49500 & 49000 & -600 & 0.000 \\
\hline Pastoral workers & & 1100 & - & 600 & 0.125 \\
\hline Theologians & $600 \overline{0}$ & 6000 & & -1900 & 0.215 \\
\hline Journalists & 18000 & 19900 & $2100 \overline{0}$ & 800 & 0.001 \\
\hline Linguists & 8000 & 8800 & 8000 & -800 & 0.010 \\
\hline
\end{tabular}

Employment figures are rounded at 1,000 and realisations lower than 5,000 are replaced by _. The loss is calculated on real figures. 


\begin{tabular}{|c|c|c|c|c|c|}
\hline Occupation & $\begin{array}{r}\text { Employment } \\
1997\end{array}$ & $\begin{array}{r}\text { Forecast } \\
2002\end{array}$ & $\begin{array}{r}\text { Employment } \\
2002\end{array}$ & $\begin{array}{r}\text { Forecasting } \\
\text { error }\end{array}$ & Loss \\
\hline Agricultural auxiliary workers & 6000 & 6400 & 6000 & -700 & 0.015 \\
\hline Agricültural workers & 107000 & 104600 & 97000 & -7600 & 0.006 \\
\hline Skilled agricultural workers & 8000 & 6900 & 8000 & 1400 & 0.028 \\
\hline Environmental hygienists and agricultural representatives & 15000 & 19700 & 13000 & -6900 & 0.291 \\
\hline Agricultural scientists & 5000 & 5700 & & -5700 & 0.000 \\
\hline Agricultural machine drivers and fishermen & 12000 & 11600 & $1000 \overline{0}$ & -1600 & 0.026 \\
\hline Agricultural managers & 127000 & 122300 & 103000 & -19500 & 0.036 \\
\hline Production workers & 105000 & 112700 & 95000 & -18100 & 0.037 \\
\hline Laboratory assistants & & 2600 & & -300 & 0.017 \\
\hline Laboratory workers & $1600 \overline{0}$ & 17300 & $1300 \overline{0}$ & -3900 & 0.085 \\
\hline Technical analysts & 10000 & 10900 & 7000 & -3700 & 0.264 \\
\hline Physicists & 18000 & 19400 & 16000 & -3800 & 0.059 \\
\hline Caretakers & 29000 & 30800 & 28000 & -3200 & 0.013 \\
\hline Heads of technical service departments & 9000 & 9300 & 14000 & 4500 & 0.106 \\
\hline Mechanical engineers & 7000 & 7100 & 9000 & 1500 & 0.030 \\
\hline Construction workers & 189000 & 196000 & 185000 & -11100 & 0.004 \\
\hline Contractors and fitters & 169000 & 178100 & 195000 & 16800 & 0.007 \\
\hline Architects and construction project manager & 32000 & 35200 & 45000 & 9800 & 0.047 \\
\hline Civil engineers & 17000 & 19500 & 21000 & 1300 & 0.004 \\
\hline Civil engineering workers & 27000 & 27000 & 23000 & -4000 & 0.030 \\
\hline Skilled civil engineering workers & 29000 & 30600 & 34000 & 3600 & 0.011 \\
\hline Civil engineering designers and project leaders & 8000 & 8200 & 12000 & 3900 & 0.104 \\
\hline Metalworkers & 88000 & 91500 & 77000 & -14400 & 0.035 \\
\hline Welders and bench fitters & 62000 & 65100 & 67000 & 1700 & 0.001 \\
\hline Metal-processing managers & & 5300 & & -1100 & 0.069 \\
\hline Assembly-line workers & $2200 \overline{0}$ & 23400 & $2400 \overline{0}$ & 600 & 0.001 \\
\hline Mechanics & 205000 & 211600 & 211000 & -300 & 0.000 \\
\hline Mechanical engineering designers and heads of technical service departments & 28000 & 28900 & 27000 & -1600 & 0.003 \\
\hline Electronical engineers & 15000 & 15600 & 9000 & -6500 & 0.510 \\
\hline
\end{tabular}




\begin{tabular}{|c|c|c|c|c|c|}
\hline Occupation & $\begin{array}{r}\text { Employment } \\
1997\end{array}$ & $\begin{array}{r}\text { Forecast } \\
2002\end{array}$ & $\begin{array}{r}\text { Employment } \\
2002\end{array}$ & $\begin{array}{r}\text { Forecasting } \\
\text { error }\end{array}$ & Loss \\
\hline Fitters and electronic product controllers & 19000 & 19600 & 15000 & -4400 & 0.084 \\
\hline Electrical mechanics & 87000 & 93200 & 89000 & -3700 & 0.002 \\
\hline Electrotechnical designers and managers & 12000 & 11700 & 13000 & 1200 & 0.009 \\
\hline Electrical engineers & 8000 & 7700 & 10000 & 1900 & 0.039 \\
\hline Printing industry production workers & 24000 & 23700 & 23000 & -1100 & 0.002 \\
\hline Skilled printing workers & 39000 & 40800 & 29000 & -11700 & 0.162 \\
\hline Mechanical operators & 71000 & 70800 & 64000 & -6400 & 0.010 \\
\hline Process operators & 51000 & 53500 & 50000 & -3700 & 0.006 \\
\hline Process technicians. & 9000 & 9100 & 10000 & 1300 & 0.016 \\
\hline Material scientists & 16000 & 19500 & 12000 & -7600 & 0.408 \\
\hline Textile workers & 34000 & 35500 & 29000 & -6600 & 0.052 \\
\hline Cobblers and tailors & 6000 & 6100 & 5000 & -700 & 0.017 \\
\hline Loaders and unloaders & 101000 & 110900 & 127000 & 15800 & 0.016 \\
\hline 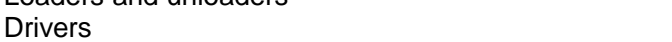 & 226000 & 249700 & 244000 & -5900 & 0.001 \\
\hline Ship's officers and conductors & 15000 & 11000 & 14000 & 3300 & 0.053 \\
\hline Pilots, ship captains and transport directors & 14000 & 16300 & 18000 & 1800 & 0.010 \\
\hline Stewards & 9000 & 15800 & 10000 & -6000 & 0.375 \\
\hline Nursing aids and student nurses & 23000 & 22400 & 31000 & 8900 & 0.081 \\
\hline Nurses and medical assistants & 113000 & 116600 & 117000 & 100 & 0.000 \\
\hline Therapists and nurses & 98000 & 97700 & 118000 & 20100 & 0.029 \\
\hline Physicians & 55000 & 61400 & 71000 & 10000 & 0.020 \\
\hline Pharmacy assistants medical laboratory staff & 40000 & 44000 & 48000 & 3700 & 0.006 \\
\hline Medical analysts & 16000 & 17900 & 19000 & 1600 & 0.007 \\
\hline Pharmacists & 7000 & 6700 & 8000 & 1200 & 0.023 \\
\hline Department heads in care institutions & 9000 & 9200 & 8000 & -1200 & 0.023 \\
\hline Office assistants, packers and door-to-door salesmen & 56000 & 63200 & 57000 & -5800 & 0.010 \\
\hline Auxiliary administrative assistants & 8000 & 9800 & 9000 & -1000 & 0.013 \\
\hline 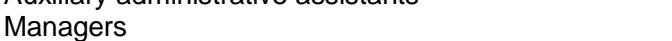 & 26000 & 26200 & 50000 & 23800 & 0.227 \\
\hline Economists & 16000 & 16600 & 10000 & -6100 & 0.338 \\
\hline
\end{tabular}




\begin{tabular}{|c|c|c|c|c|c|}
\hline Occupation & $\begin{array}{r}\text { Employment } \\
1997\end{array}$ & $\begin{array}{r}\text { Forecast } \\
2002\end{array}$ & $\begin{array}{r}\text { Employment } \\
2002\end{array}$ & $\begin{array}{r}\text { Forecasting } \\
\text { error }\end{array}$ & Loss \\
\hline Production planners & 52000 & 77700 & 58000 & -19900 & 0.119 \\
\hline Organisational consultants & 42000 & 57400 & 52000 & -4900 & 0.009 \\
\hline Organisational experts & 23000 & 30200 & 24000 & -6500 & 0.075 \\
\hline Receptionists and administrative employees & 228000 & 218400 & 254000 & 35800 & 0.020 \\
\hline Accountants and secretaries & 409000 & 503800 & 480000 & -24200 & 0.003 \\
\hline Assistant accountants & 97000 & 108700 & 106000 & -3100 & 0.001 \\
\hline Accountants & 34000 & 44100 & 34000 & -9700 & 0.080 \\
\hline Insurance brokers & 31000 & 32000 & 19000 & -13300 & 0.506 \\
\hline Purchasing clerks & 304000 & 314700 & 299000 & -15500 & 0.003 \\
\hline Commercial staff & 190000 & 219400 & 239000 & 19500 & 0.007 \\
\hline Technical and commercial employees & 16000 & 17800 & 16000 & -1300 & 0.006 \\
\hline Technical and administrative staff & 13000 & 13900 & 13000 & -900 & 0.005 \\
\hline Legal and tax office employees & 36000 & 37300 & 38000 & 1000 & 0.001 \\
\hline Legal staff and higher civil servants & 17000 & 17200 & 19000 & 2300 & 0.014 \\
\hline Lawyers & 61000 & 66400 & 69000 & 2600 & 0.001 \\
\hline Administrative transport employees & 27000 & 26300 & 29000 & 2700 & 0.009 \\
\hline Managers & 46000 & 52200 & 61000 & 8800 & 0.021 \\
\hline Managing directors & 95000 & 102800 & 115000 & 12600 & 0.012 \\
\hline Medical secretaries & 18000 & 21600 & 26000 & 4200 & 0.027 \\
\hline Programmers & 60000 & 68600 & 91000 & 22300 & 0.060 \\
\hline Systems analysts & 93000 & 111500 & 148000 & 36200 & 0.060 \\
\hline Information scientists & 14000 & 17100 & 40000 & 22800 & 0.327 \\
\hline Technical systems analysts & 10000 & 10800 & 14000 & 2900 & 0.045 \\
\hline Activity supervisors and employment intermediaries & 71000 & 80800 & 80000 & -1200 & 0.000 \\
\hline Socio-cultural workers & 84000 & 89500 & 99000 & 9500 & 0.009 \\
\hline Social counsellors and heads of personnel & 9000 & 11500 & 11000 & -900 & 0.007 \\
\hline Social-science staff & 9000 & 11800 & 14000 & 2200 & 0.025 \\
\hline Social researchers & 23000 & 28300 & 32000 & 4000 & 0.015 \\
\hline Shelf stockers & 24000 & 26900 & 38000 & 11400 & 0.089 \\
\hline
\end{tabular}




\begin{tabular}{|c|c|c|c|c|c|}
\hline Occupation & $\begin{array}{r}\text { Employment } \\
1997\end{array}$ & $\begin{array}{r}\text { Forecast } \\
2002\end{array}$ & $\begin{array}{r}\text { Employment } \\
2002\end{array}$ & $\begin{array}{r}\text { Forecasting } \\
\text { error }\end{array}$ & Loss \\
\hline Cleaning staff & 152000 & 169100 & 184000 & 14400 & 0.006 \\
\hline Sales assistants & 253000 & 272400 & 258000 & -14500 & 0.003 \\
\hline Shopkeepers & 124000 & 132800 & 138000 & 5500 & 0.002 \\
\hline Auxiliary catering and service workers & 148000 & 152800 & 174000 & 20800 & 0.014 \\
\hline Home nursing personnel & 64000 & 82500 & 80000 & -2200 & 0.001 \\
\hline Catering personnel & 185000 & 216800 & 211000 & -5600 & 0.001 \\
\hline Pub and snackbar owners & 13000 & 14300 & 16000 & 2100 & 0.016 \\
\hline Catering managers & 37000 & 40400 & 52000 & 12100 & 0.053 \\
\hline Bakers and butchers & 16000 & 16600 & 12000 & -5100 & 0.197 \\
\hline Trainee policemen, soldiers and assistant security personnel & 48000 & 52300 & 51000 & -1700 & 0.001 \\
\hline Policemen, police officers and security employees & 52000 & 48900 & 51000 & 2500 & 0.002 \\
\hline Police inspectors and senior officers & 7000 & 7100 & 6000 & -1500 & 0.072 \\
\hline Firemen & 6000 & 5600 & 8000 & 2000 & 0.069 \\
\hline
\end{tabular}


Table 22

Forecasting quality of replacement demand by occupational groups

\begin{tabular}{|c|c|c|c|c|c|}
\hline Occupation & $\begin{array}{r}\text { Reference } \\
\text { forecast }\end{array}$ & Forecast & Realisation & $\begin{array}{r}\text { Forecasting } \\
\text { error }\end{array}$ & Loss \\
\hline Primary school teachers & 22600 & 25300 & 20900 & -4400 & 0.001 \\
\hline Teachers of science, medical, hotel and catering subjects (2nd and 3rd degree) & 3200 & 4000 & 3800 & -200 & 0.000 \\
\hline Teachers of science, medical, hotel and catering subjects ( 1 st degree and UE) & 2400 & 4700 & 3800 & -900 & 0.004 \\
\hline Agricultural and technical teachers (2nd and 3rd degree) & 2600 & 6200 & 4500 & -1700 & 0.012 \\
\hline Agricultural and technical teachers ( 1 st degree and UE) & 500 & 1100 & 900 & -200 & 0.003 \\
\hline Teachers of economic and administrative subjects ( 2 nd and 3rd degree) & 1100 & 2400 & 1400 & -1000 & 0.024 \\
\hline Teachers of economic and administrative subjects ( 1 st degree and UE) & 1800 & 1200 & 1800 & 600 & 0.004 \\
\hline Language and arts teachers & 5800 & 10200 & 8400 & -1800 & 0.003 \\
\hline Language teachers ( 1 st degree and UE) & 3900 & 5100 & 5700 & 600 & 0.001 \\
\hline Teachers of social, psychological subjects (2nd and 3rd degree) & 1800 & 3000 & 2200 & -800 & 0.006 \\
\hline Teachers of social subjects(1st degree and UE) & 1200 & 1600 & 1600 & 0 & 0.000 \\
\hline 2nd and 3rd degree teachers no specialisation & 1800 & 2500 & 2000 & -500 & 0.002 \\
\hline 1 st degree teachers, no specialisation & 500 & 800 & 600 & -200 & 0.003 \\
\hline Pedagogical staff & 1400 & 2300 & 1600 & -700 & 0.009 \\
\hline Educational scientists and pedagogues & 3200 & 3000 & 2500 & -500 & 0.001 \\
\hline Driving instructors & 1100 & 2000 & 1400 & -600 & 0.009 \\
\hline Swimming instructors & 600 & 600 & 400 & -200 & 0.003 \\
\hline Sports instructors & 1400 & 1200 & 800 & -400 & 0.003 \\
\hline Interpreters, translators and writers & 1400 & 1700 & 1600 & -100 & 0.000 \\
\hline Library assistants & 3700 & 3200 & 3700 & 500 & 0.000 \\
\hline Librarians & 1700 & 2800 & 1900 & -900 & 0.009 \\
\hline Graphic designers & 1400 & 1100 & 600 & -500 & 0.004 \\
\hline Artists & 7800 & 7400 & 7200 & -200 & 0.000 \\
\hline Pastoral workers & 200 & 900 & 600 & -300 & 0.041 \\
\hline Theologians & 1000 & 900 & 1300 & 400 & 0.004 \\
\hline Journalists & 3100 & 2500 & 2000 & -500 & 0.001 \\
\hline Linguists & 1400 & 1400 & 1200 & -200 & 0.001 \\
\hline Agricultural auxiliary workers & 1000 & 1000 & 700 & -300 & 0.002 \\
\hline
\end{tabular}




\begin{tabular}{|c|c|c|c|c|c|}
\hline Occupation & $\begin{array}{r}\text { Reference } \\
\text { forecast }\end{array}$ & Forecast & Realisation & $\begin{array}{r}\text { Forecasting } \\
\text { error }\end{array}$ & Loss \\
\hline Agricültural workers & 18300 & 19800 & 13000 & -6800 & 0.004 \\
\hline Skilled agricultural workers & 1300 & 1100 & 1100 & 0 & 0.000 \\
\hline Environmental hygienists and agricultural representatives & 2500 & 2600 & 2200 & -400 & 0.001 \\
\hline Agricultural scientists & 800 & 800 & 600 & -200 & 0.002 \\
\hline Agricultural machine drivers and fishermen & 2000 & 1700 & 1600 & -100 & 0.000 \\
\hline Agricultural managers & 21800 & 26300 & 23000 & -3300 & 0.001 \\
\hline Production workers & 18000 & 15100 & 12200 & -2900 & 0.001 \\
\hline Laboratory assistants & 400 & 400 & 500 & 100 & 0.001 \\
\hline Laboratory workers & 2800 & 2900 & 2400 & -500 & 0.001 \\
\hline Technical analysts & 1600 & 2100 & 1300 & -800 & 0.007 \\
\hline Physicists & 3000 & 2900 & 2100 & -800 & 0.002 \\
\hline Caretakers & 4900 & 9300 & 5900 & -3400 & 0.014 \\
\hline Heads of technical service departments & 1600 & 2400 & 2200 & -200 & 0.000 \\
\hline Mechanical engineers & 1200 & 1600 & 1600 & 0 & 0.000 \\
\hline Construction workers & 32400 & 33100 & 14200 & -18900 & 0.010 \\
\hline Contractors and fitters & 29000 & 30700 & 23500 & -7200 & 0.002 \\
\hline Architects and construction project manager & 5500 & 7600 & 5900 & -1700 & 0.003 \\
\hline Civil engineers & 2800 & 2500 & 2800 & 300 & 0.000 \\
\hline Civil engineering workers & 4600 & 4200 & 2100 & -2100 & 0.006 \\
\hline Skilled civil engineering workers & 5000 & 6300 & 4800 & -1500 & 0.003 \\
\hline Civil engineering designers and project leaders & 1400 & 1500 & 1500 & 0 & 0.000 \\
\hline Metalworkers & 15200 & 18100 & 7200 & -10900 & 0.015 \\
\hline Welders and bench fitters & 10700 & 10100 & 9300 & -800 & 0.000 \\
\hline Metal-processing managers & 700 & 1200 & 1000 & -200 & 0.002 \\
\hline Assembly-line workers & 3800 & 3500 & 1600 & -1900 & 0.008 \\
\hline Mechanics & 35100 & 28300 & 29500 & 1200 & 0.000 \\
\hline Mechanical engineering designers and heads of technical service departments & 4800 & 7400 & 6900 & -500 & 0.000 \\
\hline Electronical engineers & 2500 & 2200 & 2300 & 100 & 0.000 \\
\hline Fitters and electronic product controllers & 3300 & 2800 & 1400 & -1400 & 0.005 \\
\hline
\end{tabular}




\begin{tabular}{|c|c|c|c|c|c|}
\hline Occupation & $\begin{array}{r}\text { Reference } \\
\text { forecast }\end{array}$ & Forecast & Realisation & $\begin{array}{r}\text { Forecasting } \\
\text { error }\end{array}$ & Loss \\
\hline Electrical mechanics & 15000 & 14200 & 13500 & -700 & 0.000 \\
\hline Electrotechnical designers and managers & 2000 & 2800 & 2400 & -400 & 0.001 \\
\hline Electrical engineers & 1400 & 1000 & 1200 & 200 & 0.001 \\
\hline Printing industry production workers & 4200 & 4000 & 2000 & -2000 & 0.007 \\
\hline Skilled printing workers & 6700 & 6200 & 7900 & 1700 & 0.002 \\
\hline Mechanical operators & 12100 & 13900 & 6100 & -7800 & 0.012 \\
\hline Process operators & 8800 & 7900 & 6800 & -1100 & 0.000 \\
\hline Process technicians. & 1600 & 2600 & 1800 & -800 & 0.008 \\
\hline Material scientists & 2700 & 3100 & 3200 & 100 & 0.000 \\
\hline Textile workers & 5700 & 8800 & 4500 & -4300 & 0.016 \\
\hline Cobblers and tailors & 1000 & 1700 & 1300 & -400 & 0.004 \\
\hline Loaders and unloaders & 17300 & 11000 & 8400 & -2600 & 0.001 \\
\hline Drivers & 38700 & 36500 & 40400 & 3900 & 0.000 \\
\hline Ship's officers and conductors & 2500 & 3500 & 2700 & -800 & 0.003 \\
\hline Pilots, ship captains and transport directors & 2500 & 2500 & 2800 & 300 & 0.000 \\
\hline Stewards & 1600 & 1200 & 800 & -400 & 0.002 \\
\hline Nursing aids and student nurses & 3900 & 8200 & 2400 & -5800 & 0.065 \\
\hline Nurses and medical assistants & 19400 & 18800 & 12800 & -6000 & 0.003 \\
\hline Therapists and nurses & 16700 & 20100 & 13400 & -6700 & 0.005 \\
\hline Physicians & 9500 & 12500 & 10700 & -1800 & 0.001 \\
\hline Pharmacy assistants medical laboratory staff & 6800 & 6800 & 3900 & -2900 & 0.006 \\
\hline Medical analysts & 2800 & 2900 & 1600 & -1300 & 0.006 \\
\hline Pharmacists & 1200 & 1100 & 1100 & 0 & 0.000 \\
\hline Department heads in care institutions & 1600 & 2700 & 1300 & -1400 & 0.024 \\
\hline Office assistants, packers and door-to-door salesmen & 9600 & 6700 & 8700 & 2000 & 0.001 \\
\hline Auxiliary administrative assistants & 1400 & 1600 & 1300 & -300 & 0.002 \\
\hline Managers & 4400 & 3700 & 4300 & 600 & 0.001 \\
\hline Economists & 2700 & 1700 & 1300 & -400 & 0.001 \\
\hline Production planners & 8900 & 7100 & 4500 & -2600 & 0.002 \\
\hline Organisational consultants & 7200 & 4400 & 4600 & 200 & 0.000 \\
\hline
\end{tabular}




\begin{tabular}{|c|c|c|c|c|c|}
\hline Occupation & $\begin{array}{r}\text { Reference } \\
\text { forecast }\end{array}$ & Forecast & Realisation & $\begin{array}{r}\text { Forecasting } \\
\text { error }\end{array}$ & Loss \\
\hline Organisational experts & 4000 & 2600 & 4400 & 1800 & 0.006 \\
\hline Receptionists and administrative employees & 39000 & 57700 & 31400 & -26300 & 0.013 \\
\hline Accountants and secretaries & 70100 & 54500 & 70300 & 15800 & 0.001 \\
\hline Assistant accountants & 16600 & 15300 & 10100 & -5200 & 0.003 \\
\hline Accountants & 5800 & 4000 & 6200 & 2200 & 0.004 \\
\hline Insurance brokers & 5300 & 6200 & 2400 & -3800 & 0.015 \\
\hline Purchasing clerks & 52100 & 34900 & 34400 & -500 & 0.000 \\
\hline Commercial staff & 32600 & 26100 & 35000 & 8900 & 0.002 \\
\hline Technical and commercial employees & 2800 & 2500 & 2400 & -100 & 0.000 \\
\hline Technical and administrative staff & 2300 & 1800 & 2100 & 300 & 0.001 \\
\hline Legal and tax office employees & 6200 & 6800 & 6000 & -800 & 0.001 \\
\hline Legal staff and higher civil servants & 2800 & 4900 & 3200 & -1700 & 0.011 \\
\hline Lawyers & 10500 & 6800 & 8200 & 1400 & 0.000 \\
\hline Administrative transport employees & 4700 & 6100 & 3500 & -2600 & 0.009 \\
\hline Managers & 7800 & 9500 & 9400 & -100 & 0.000 \\
\hline Managing directors & 16400 & 20300 & 24600 & 4300 & 0.002 \\
\hline Medical secretaries & 3100 & 3300 & 1900 & -1400 & 0.006 \\
\hline Programmers & 10300 & 4800 & 4200 & -600 & 0.000 \\
\hline Systems analysts & 15900 & 11000 & 5800 & -5200 & 0.003 \\
\hline Information scientists & 2400 & 1600 & 1200 & -400 & 0.001 \\
\hline Technical systems analysts & 1700 & 1800 & 500 & -1300 & 0.017 \\
\hline Activity supervisors and employment intermediaries & 12200 & 6000 & 6000 & 0 & 0.000 \\
\hline Socio-cultural workers & 14400 & 10800 & 9700 & -1100 & 0.000 \\
\hline Social counsellors and heads of personnel & 1600 & 1800 & 1900 & 100 & 0.000 \\
\hline Social-science staff & 1600 & 1400 & 1400 & 0 & 0.000 \\
\hline Social researchers & 3900 & 3100 & 3600 & 500 & 0.001 \\
\hline Shelf stockers & 4100 & 7300 & 900 & -6400 & 0.072 \\
\hline Cleaning staff & 26100 & 27700 & 25200 & -2500 & 0.000 \\
\hline Sales assistants & 43400 & 45600 & 22500 & -23100 & 0.008 \\
\hline Shopkeepers & 21300 & 22200 & 27900 & 5700 & 0.002 \\
\hline
\end{tabular}




\begin{tabular}{|c|c|c|c|c|c|}
\hline Occupation & $\begin{array}{r}\text { Reference } \\
\text { forecast }\end{array}$ & Forecast & Realisation & $\begin{array}{r}\text { Forecasting } \\
\text { error }\end{array}$ & Loss \\
\hline Auxiliary catering and service workers & 25400 & 31700 & 19200 & -12500 & 0.007 \\
\hline Home nursing personnel & 11000 & 10600 & 6900 & -3700 & 0.003 \\
\hline Catering personnel & 31700 & 24100 & 16700 & -7400 & 0.002 \\
\hline Pub and snackbar owners & 2200 & 4500 & 2900 & -1600 & 0.016 \\
\hline Catering managers & 6300 & 7700 & 7100 & -600 & 0.000 \\
\hline Bakers and butchers & 2800 & 2700 & 2400 & -300 & 0.000 \\
\hline Trainee policemen, soldiers and assistant security personnel & 8300 & 7800 & 5100 & -2700 & 0.003 \\
\hline Policemen, police officers and security employees & 8900 & 8500 & 6500 & -2000 & 0.001 \\
\hline Police inspectors and senior officers & 1200 & 900 & 1000 & 100 & 0.000 \\
\hline Firemen & 900 & 1600 & 1100 & -500 & 0.010 \\
\hline
\end{tabular}


Table 23

Forecasting quality of replacement demand by educational types

\begin{tabular}{|c|c|c|c|c|c|}
\hline Education & $\begin{array}{r}\text { Reference } \\
\text { forecast }\end{array}$ & Forecast & Realisation & $\begin{array}{r}\text { Forecasting } \\
\text { error }\end{array}$ & Loss \\
\hline Primary Education & 97100 & 111100 & 128200 & 17100 & 0.001 \\
\hline Lower General Secondary Education & 83100 & 122500 & 94100 & -28400 & 0.005 \\
\hline PVE Agriculture & 15300 & 15200 & 8400 & -6800 & 0.008 \\
\hline PVE Construction trades & 26800 & 26900 & 18500 & -8400 & 0.004 \\
\hline PVE Utilities installation & 3400 & 2900 & 1300 & -1600 & 0.009 \\
\hline PVE Mechanical trades & 23600 & 30600 & 23200 & -7400 & 0.004 \\
\hline PVE Precision Mechanical trades & 1000 & 1000 & 1000 & 0 & 0.000 \\
\hline PVE Automobile trades & 8400 & 8400 & 7200 & -1200 & 0.001 \\
\hline PVE Electrical trades & 13400 & 15300 & 7900 & -7400 & 0.013 \\
\hline PVE Printing trades & 1200 & 1900 & 1000 & -900 & 0.027 \\
\hline PVE Food trades & 2700 & 2500 & 1800 & -700 & 0.003 \\
\hline PVE Transport and harbour & 6100 & 8200 & 4700 & -3500 & 0.014 \\
\hline PVE others technical & 7600 & 8700 & 8300 & -400 & 0.000 \\
\hline PVE Administration and Textile and leather trades & 10100 & 11100 & 23700 & 12600 & 0.064 \\
\hline PVE Commerce & 24600 & 23200 & 2900 & -20300 & 0.028 \\
\hline PVE Community care, hotel and catering & 36800 & 51900 & 37400 & -14500 & 0.006 \\
\hline PVE Security & 2400 & 1000 & 1700 & 700 & 0.004 \\
\hline PVE Others & 2700 & 5000 & 3900 & -1100 & 0.007 \\
\hline Higher General Secondary Education & 65800 & 72700 & 64000 & -8700 & 0.001 \\
\hline IVE Agriculture & 22600 & 20200 & 13900 & -6300 & 0.003 \\
\hline IVE Natural environment & 4800 & 3100 & 1900 & -1200 & 0.003 \\
\hline IVE Technical Laboratory & 3700 & 5200 & 1800 & -3400 & 0.035 \\
\hline IVE Construction technology & 27700 & 26500 & 25400 & -1100 & 0.000 \\
\hline IVE Civil engineering & 5000 & 5300 & 3400 & -1900 & 0.006 \\
\hline IVE Instalation & 5000 & 4000 & 4400 & 400 & 0.000 \\
\hline IVE Mechanical engineering & 28800 & 31400 & 28100 & -3300 & 0.001 \\
\hline IVE Precision engineering & 3000 & 2800 & 3100 & 300 & 0.000 \\
\hline
\end{tabular}




\begin{tabular}{|c|c|c|c|c|c|}
\hline Education & $\begin{array}{r}\text { Reference } \\
\text { forecast }\end{array}$ & Forecast & Realisation & $\begin{array}{r}\text { Forecasting } \\
\text { error }\end{array}$ & Loss \\
\hline IVE Automobile technology & 14600 & 13900 & 11600 & -2300 & 0.001 \\
\hline IVE Aircraft technology & 1300 & 1700 & 800 & -900 & 0.019 \\
\hline IVE Operational technology & 1500 & 1200 & 1000 & -200 & 0.000 \\
\hline IVE Electrical technology & 32300 & 25900 & 28300 & 2400 & 0.000 \\
\hline IVE Printing technology & 8200 & 6800 & 7000 & 200 & 0.000 \\
\hline IVE Process technologies & 5100 & 3400 & 2800 & -600 & 0.000 \\
\hline IVE Bakery and catering technology & 2900 & 2800 & 2300 & -500 & 0.001 \\
\hline IVE Food technology & 4700 & 4000 & 3600 & -400 & 0.000 \\
\hline IVE Transport and harbour & 10900 & 8400 & 10800 & 2400 & 0.002 \\
\hline IVE Other technology & 7200 & 6800 & 7600 & 800 & 0.000 \\
\hline IVE Doctors, dentists and veterinaries assistant & 4300 & 2600 & 1900 & -700 & 0.001 \\
\hline IVE Pharmasists assistant & 3400 & 2900 & 3500 & 600 & 0.001 \\
\hline IVE Nursing and paramedical services & 24700 & 23200 & 22400 & -800 & 0.000 \\
\hline IVE Medical laboratory & 1200 & 900 & 1100 & 200 & 0.001 \\
\hline IVE Social and cultural & 12200 & 10300 & 10800 & 500 & 0.000 \\
\hline IVE Community care & 38500 & 32600 & 24500 & -8100 & 0.002 \\
\hline IVE hairdressing, Manicures & 12500 & 10800 & 8100 & -2700 & 0.002 \\
\hline IVE Hotel, catering & 15400 & 12600 & 11500 & -1100 & 0.000 \\
\hline IVE Therapeutics and Orthopaedics & 5400 & 3800 & 4100 & 300 & 0.000 \\
\hline IVE Administration & 57800 & 43200 & 58000 & 14800 & 0.003 \\
\hline IVE Retail & 59500 & 52900 & 53600 & 700 & 0.000 \\
\hline IVE Secretariat & 21000 & 18700 & 14200 & -4500 & 0.002 \\
\hline IVE Tourism and recreation & 3700 & 700 & 4300 & 3600 & 0.040 \\
\hline IVE Commerce & 7400 & 7100 & 7100 & 0 & 0.000 \\
\hline IVE Automatisering & 7800 & 4000 & 5800 & 1800 & 0.002 \\
\hline IVE Legal and fiscal & 6500 & 4800 & 6000 & 1200 & 0.001 \\
\hline IVE Assurances & 5400 & 4700 & 5000 & 300 & 0.000 \\
\hline IVE Police, fire and defense & 19000 & 20900 & 14200 & -6700 & 0.005 \\
\hline IVE Others & 3600 & 4800 & 6100 & 1300 & 0.005 \\
\hline
\end{tabular}




\begin{tabular}{|c|c|c|c|c|c|}
\hline Education & $\begin{array}{r}\text { Reference } \\
\text { forecast }\end{array}$ & Forecast & Realisation & $\begin{array}{r}\text { Forecasting } \\
\text { error }\end{array}$ & Loss \\
\hline HVE Teacher training primary education & 32400 & 28200 & 31600 & 3400 & 0.000 \\
\hline HVE Teacher training languages & 6200 & 8300 & 7900 & -400 & 0.000 \\
\hline HVE Teacher training technology and natural sciences & 7400 & 7200 & 6900 & -300 & 0.000 \\
\hline HVE Teacher training economics and Sociology & 7400 & 7200 & 9600 & 2400 & 0.004 \\
\hline HVE Teacher training physical education & 5100 & 2500 & 2500 & 0 & 0.000 \\
\hline HVE Teacher training health & 3400 & 3200 & 3900 & 700 & 0.002 \\
\hline HVE Teacher training expression & 6500 & 7500 & 8500 & 1000 & 0.001 \\
\hline HVE Teacher training interpreter and translator & 1900 & 1000 & 1300 & 300 & 0.001 \\
\hline HVE Agriculture and environmental science & 1700 & 1900 & 700 & -1200 & 0.019 \\
\hline HVE Environment sciences & 3000 & 2600 & 3300 & 700 & 0.002 \\
\hline HVE Technical laboratory & 6800 & 8500 & 6500 & -2000 & 0.004 \\
\hline HVE Construction & 3900 & 4400 & 3500 & -900 & 0.002 \\
\hline HVE Civil engineering & 3500 & 3500 & 3100 & -400 & 0.001 \\
\hline HVE Mechanical engineering & 7500 & 8200 & 6700 & -1500 & 0.002 \\
\hline HVE Electronic & 8400 & 6500 & 7800 & 1300 & 0.001 \\
\hline HVE Information technology & 7600 & 5100 & 3500 & -1600 & 0.002 \\
\hline HVE Chemical technology & 1700 & 2000 & 1500 & -500 & 0.003 \\
\hline HVE Transport and harbour & 4700 & 5400 & 5300 & -100 & 0.000 \\
\hline HVE Nursing and paramedical services & 10700 & 8800 & 6800 & -2000 & 0.001 \\
\hline HVE (Physio)therapy & 7800 & 5700 & 8300 & 2600 & 0.005 \\
\hline HVE Nutritionist & 1000 & 800 & 600 & -200 & 0.001 \\
\hline HVE Radiologist & 1300 & 900 & 1000 & 100 & 0.000 \\
\hline HVE Other paramedical & 1900 & 1000 & 2100 & 1100 & 0.015 \\
\hline HVE Economics & 11800 & 13600 & 8300 & -5300 & 0.008 \\
\hline HVE Commerce & 8500 & 7800 & 3800 & -4000 & 0.009 \\
\hline HVE Tourism and recreation & 1900 & 2300 & 300 & -2000 & 0.047 \\
\hline HVE Legal and fiscal & 4500 & 4400 & 2600 & -1800 & 0.006 \\
\hline HVE Secretariat & 6400 & 7500 & 4100 & -3400 & 0.012 \\
\hline HVE Business administration & 13300 & 13300 & 6200 & -7100 & 0.012 \\
\hline
\end{tabular}




\begin{tabular}{|c|c|c|c|c|c|}
\hline Education & $\begin{array}{r}\text { Reference } \\
\text { forecast }\end{array}$ & Forecast & Realisation & $\begin{array}{r}\text { Forecasting } \\
\text { error }\end{array}$ & Loss \\
\hline HVE Communication and journalism & 3400 & 1700 & 1200 & -500 & 0.001 \\
\hline HVE Social and cultural & 15100 & 13300 & 15900 & 2600 & 0.001 \\
\hline HVE Human resources & 3700 & 3300 & 2500 & -800 & 0.002 \\
\hline HVE Librarian & 2800 & 2200 & 2700 & 500 & 0.001 \\
\hline HVE Other social and cultural & 2700 & 2900 & 1700 & -1200 & 0.008 \\
\hline HVE Fine Arts & 9600 & 10700 & 9400 & -1300 & 0.001 \\
\hline HVE Police, fire and defense & 2000 & 2200 & 2100 & -100 & 0.000 \\
\hline HVE Others & 5800 & 3300 & 6000 & 2700 & 0.009 \\
\hline UE Literature & 9200 & 9100 & 6900 & -2200 & 0.002 \\
\hline UE Theology & 1200 & 1500 & 1900 & 400 & 0.005 \\
\hline UE Agriculture and environmental science & 2400 & 1300 & 1100 & -200 & 0.000 \\
\hline UE Mathematics and natural sciences & 12600 & 12700 & 11400 & -1300 & 0.000 \\
\hline UE Construction and civil engineering & 1900 & 1900 & 1600 & -300 & 0.001 \\
\hline UE Civil engineering & 1400 & 1800 & 1400 & -400 & 0.004 \\
\hline UE Mechanical engineering & 2000 & 1700 & 1700 & 0 & 0.000 \\
\hline UE Electrical engineering and inform. tech. & 1800 & 1700 & 1500 & -200 & 0.001 \\
\hline UE Information science & 1600 & 800 & 400 & -400 & 0.003 \\
\hline UE Veterinary and medical science & 8600 & 9000 & 7100 & -1900 & 0.002 \\
\hline UE Dentist & 1300 & 1400 & 900 & -500 & 0.006 \\
\hline UE Pharmacy & 1700 & 900 & 500 & -400 & 0.002 \\
\hline UE Econom-ics (-etry) & 8600 & 8600 & 5200 & -3400 & 0.007 \\
\hline UE Business administration & 4300 & 3200 & 1100 & -2100 & 0.010 \\
\hline UE Accounting & 3800 & 3900 & 2300 & -1600 & 0.007 \\
\hline UE Law \& Management & 11600 & 11400 & 8700 & -2700 & 0.002 \\
\hline UE Social sciences & 16900 & 14200 & 12200 & -2000 & 0.001 \\
\hline UE Other socio-cultural & 2900 & 3800 & 3700 & -100 & 0.000 \\
\hline UE Fine Arts & 1000 & 700 & 700 & 0 & 0.000 \\
\hline UE Others & 2700 & 900 & 1600 & 700 & 0.003 \\
\hline
\end{tabular}


Table 24

Forecasting quality of Job openings by occupational groups

\begin{tabular}{|c|c|c|c|c|}
\hline Occupation & Forecast & Realisation & $\begin{array}{r}\text { Forecasting } \\
\text { error }\end{array}$ & Loss \\
\hline Primary school teachers & 27900 & 42300 & 14400 & 0.012 \\
\hline Teachers of science, medical, hotel and catering subjects (2nd and 3rd degree) & 4000 & 8700 & 4700 & 0.063 \\
\hline Teachers of science, medical, hotel and catering subjects ( 1 st degree and UE) & 7000 & 3800 & -3200 & 0.053 \\
\hline Agricultural and technical teachers (2nd and 3rd degree) & 6200 & 5800 & -400 & 0.001 \\
\hline Agricultural and technical teachers ( 1 st degree and UE) & 1300 & 3700 & 2400 & 0.662 \\
\hline Teachers of economic and administrative subjects (2nd and 3rd degree) & 2400 & 11100 & 8700 & 1.785 \\
\hline Teachers of economic and administrative subjects ( 1 st degree and UE) & 1500 & 1800 & 300 & 0.001 \\
\hline Language and arts teachers & 10200 & 19700 & 9500 & 0.077 \\
\hline Language teachers ( 1 st degree and UE) & 10400 & 5700 & -4700 & 0.041 \\
\hline Teachers of social, psychological subjects (2nd and 3rd degree) & 3000 & 7400 & 4400 & 0.180 \\
\hline Teachers of social subjects(1st degree and UE) & 1600 & 1800 & 200 & 0.001 \\
\hline 2nd and 3rd degree teachers no specialisation & 3300 & 2000 & -1300 & 0.015 \\
\hline 1 st degree teachers, no specialisation & 1500 & 600 & -900 & 0.078 \\
\hline Pedagogical staff & 5100 & 4000 & -1100 & 0.021 \\
\hline Educational scientists and pedagogues & 6000 & 6100 & 100 & 0.000 \\
\hline Driving instructors & 2300 & 2800 & 500 & 0.005 \\
\hline Swimming instructors & 900 & 400 & -500 & 0.019 \\
\hline Sports instructors & 1600 & 4600 & 3000 & 0.130 \\
\hline Interpreters, translators and writers & 2800 & 7000 & 4200 & 0.282 \\
\hline Library assistants & 3200 & 3700 & 500 & 0.000 \\
\hline Librarians & 3400 & 1900 & -1500 & 0.024 \\
\hline Graphic designers & 3800 & 3100 & -700 & 0.008 \\
\hline Artists & 11200 & 10400 & -800 & 0.000 \\
\hline Pastoral workers & 900 & 900 & 0 & 0.000 \\
\hline Theologians & 900 & 1300 & 400 & 0.004 \\
\hline Journalists & 4100 & 4400 & 300 & 0.000 \\
\hline Linguists & 2100 & 1200 & -900 & 0.014 \\
\hline Agricultural auxiliary workers & 1600 & 700 & -900 & 0.023 \\
\hline
\end{tabular}




\begin{tabular}{|c|c|c|c|c|}
\hline Occupation & Forecast & Realisation & $\begin{array}{r}\text { Forecasting } \\
\text { error }\end{array}$ & Loss \\
\hline Agricültural workers & 19800 & 13000 & -6800 & 0.004 \\
\hline Skilled agricultural workers & 1100 & 1700 & 600 & 0.006 \\
\hline Environmental hygienists and agricultural representatives & 7800 & 2200 & -5600 & 0.150 \\
\hline Agricultural scientists & 1900 & 600 & -1300 & 0.080 \\
\hline Agricultural machine drivers and fishermen & 1700 & 1600 & -100 & 0.000 \\
\hline Agricultural managers & 26300 & 23000 & -3300 & 0.001 \\
\hline Production workers & 23100 & 12200 & -10900 & 0.011 \\
\hline Laboratory assistants & 700 & 500 & -200 & 0.011 \\
\hline Laboratory workers & 3900 & 2400 & -1500 & 0.009 \\
\hline Technical analysts & 3500 & 1300 & -2200 & 0.053 \\
\hline Physicists & 4600 & 2100 & -2500 & 0.020 \\
\hline Caretakers & 11400 & 5900 & -5500 & 0.037 \\
\hline Heads of technical service departments & 2400 & 6700 & 4300 & 0.213 \\
\hline Mechanical engineers & 1900 & 3400 & 1500 & 0.046 \\
\hline Construction workers & 40100 & 14200 & -25900 & 0.019 \\
\hline Contractors and fitters & 39900 & 49500 & 9600 & 0.003 \\
\hline Architects and construction project manager & 11000 & 19100 & 8100 & 0.065 \\
\hline Civil engineers & 5400 & 7000 & 1600 & 0.009 \\
\hline Civil engineering workers & 4200 & 2100 & -2100 & 0.006 \\
\hline Skilled civil engineering workers & 7800 & 9800 & 2000 & 0.005 \\
\hline Civil engineering designers and project leaders & 1800 & 5700 & 3900 & 0.250 \\
\hline Metalworkers & 21200 & 7200 & -14000 & 0.025 \\
\hline Welders and bench fitters & 13100 & 14000 & 900 & 0.000 \\
\hline Metal-processing managers & 2300 & 1000 & -1300 & 0.094 \\
\hline Assembly-line workers & 4900 & 3600 & -1300 & 0.004 \\
\hline Mechanics & 35400 & 36300 & 900 & 0.000 \\
\hline Mechanical engineering designers and heads of technical service departments & 8300 & 6900 & -1400 & 0.003 \\
\hline Electronical engineers & 3000 & 2300 & -700 & 0.002 \\
\hline Fitters and electronic product controllers & 3200 & 1400 & -1800 & 0.008 \\
\hline
\end{tabular}




\begin{tabular}{|c|c|c|c|c|}
\hline Occupation & Forecast & Realisation & $\begin{array}{r}\text { Forecasting } \\
\text { error }\end{array}$ & Loss \\
\hline Electrical mechanics & 20100 & 15700 & -4400 & 0.003 \\
\hline Electrotechnical designers and managers & 2800 & 3600 & 800 & 0.005 \\
\hline Electrical engineers & 1000 & 2900 & 1900 & 0.060 \\
\hline Printing industry production workers & 4000 & 2000 & -2000 & 0.007 \\
\hline Skilled printing workers & 8000 & 7900 & -100 & 0.000 \\
\hline Mechanical operators & 14200 & 6100 & -8100 & 0.013 \\
\hline Process operators & 10400 & 6800 & -3600 & 0.005 \\
\hline Process technicians. & 2600 & 3000 & 400 & 0.002 \\
\hline Material scientists & 7100 & 3200 & -3900 & 0.065 \\
\hline Textile workers & 10800 & 4500 & -6300 & 0.035 \\
\hline Cobblers and tailors & 2200 & 1300 & -900 & 0.023 \\
\hline Loaders and unloaders & 21300 & 34500 & 13200 & 0.017 \\
\hline Drivers & 60400 & 58400 & -2000 & 0.000 \\
\hline Ship's officers and conductors & 3500 & 2700 & -800 & 0.003 \\
\hline Pilots, ship captains and transport directors & 4500 & 6600 & 2100 & 0.021 \\
\hline Stewards & 7900 & 1500 & -6400 & 0.489 \\
\hline Nursing aids and student nurses & 8200 & 11200 & 3000 & 0.018 \\
\hline Nurses and medical assistants & 22200 & 16300 & -5900 & 0.003 \\
\hline Therapists and nurses & 20200 & 33600 & 13400 & 0.019 \\
\hline Physicians & 18500 & 26700 & 8200 & 0.022 \\
\hline Pharmacy assistants medical laboratory staff & 11300 & 12100 & 800 & 0.000 \\
\hline $\begin{array}{l}\text { Medical analysts } \\
\text { M }\end{array}$ & 4400 & 4700 & 300 & 0.000 \\
\hline Pharmacists & 1100 & 2200 & 1100 & 0.028 \\
\hline Department heads in care institutions & 2800 & 1300 & -1500 & 0.027 \\
\hline Office assistants, packers and door-to-door salesmen & 13700 & 9900 & -3800 & 0.004 \\
\hline Auxiliary administrative assistants & 3000 & 1700 & -1300 & 0.026 \\
\hline Managers & 4300 & 28700 & 24400 & 0.910 \\
\hline Economists & 2400 & 1300 & -1100 & 0.004 \\
\hline Production planners & 33000 & 10500 & -22500 & 0.188 \\
\hline
\end{tabular}




\begin{tabular}{|c|c|c|c|c|}
\hline Occupation & Forecast & Realisation & $\begin{array}{r}\text { Forecasting } \\
\text { error }\end{array}$ & Loss \\
\hline Organisational consultants & 19700 & 15000 & -4700 & 0.012 \\
\hline Organisational experts & 9400 & 4700 & -4700 & 0.040 \\
\hline Receptionists and administrative employees & 57700 & 58100 & 400 & 0.000 \\
\hline Accountants and secretaries & 149500 & 141100 & -8400 & 0.000 \\
\hline Assistant accountants & 27500 & 19200 & -8300 & 0.007 \\
\hline Accountants & 14100 & 6600 & -7500 & 0.049 \\
\hline Insurance brokers & 7300 & 2400 & -4900 & 0.026 \\
\hline Purchasing clerks & 45800 & 34400 & -11400 & 0.001 \\
\hline Commercial staff & 55800 & 84200 & 28400 & 0.022 \\
\hline Technical and commercial employees & 3900 & 2500 & -1400 & 0.007 \\
\hline Technical and administrative staff & 2400 & 2100 & -300 & 0.000 \\
\hline Legal and tax office employees & 7900 & 8100 & 200 & 0.000 \\
\hline Legal staff and higher civil servants & 5500 & 6100 & 600 & 0.001 \\
\hline 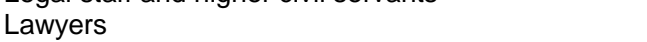 & 11800 & 15800 & 4000 & 0.004 \\
\hline Administrative transport employees & 6100 & 5300 & -800 & 0.001 \\
\hline Managers & 16100 & 24800 & 8700 & 0.036 \\
\hline Managing directors & 27700 & 44600 & 16900 & 0.032 \\
\hline Medical secretaries & 6900 & 9700 & 2800 & 0.025 \\
\hline Programmers & 13600 & 35300 & 21700 & 0.131 \\
\hline Systems analysts & 30000 & 61000 & 31000 & 0.112 \\
\hline Information scientists & 4500 & 26900 & 22400 & 2.479 \\
\hline Technical systems analysts & 2900 & 4500 & 1600 & 0.029 \\
\hline Activity supervisors and employment intermediaries & 15800 & 14600 & -1200 & 0.000 \\
\hline Socio-cultural workers & 16200 & 24600 & 8400 & 0.010 \\
\hline Social counsellors and heads of personnel & 3900 & 3100 & -800 & 0.008 \\
\hline Social-science staff & 4100 & 6300 & 2200 & 0.060 \\
\hline Social researchers & 8700 & 13200 & 4500 & 0.040 \\
\hline Shelf stockers & 10300 & 15300 & 5000 & 0.044 \\
\hline Cleaning staff & 44500 & 56400 & 11900 & 0.006 \\
\hline
\end{tabular}




\begin{tabular}{|c|c|c|c|c|}
\hline Occupation & Forecast & Realisation & $\begin{array}{r}\text { Forecasting } \\
\text { error }\end{array}$ & Loss \\
\hline $\begin{array}{l}\text { Sales assistants } \\
\text { Shopkeepers } \\
\text { Auxiliary catering and service workers } \\
\text { Home nursing personnel } \\
\text { Catering personnel } \\
\text { Pub and snackbar owners } \\
\text { Catering managers } \\
\text { Bakers and butchers } \\
\text { Trainee policemen, soldiers and assistant security personnel } \\
\text { Policemen, police officers and security employees } \\
\text { Police inspectors and senior officers } \\
\text { Firemen }\end{array}$ & $\begin{array}{r}65300 \\
30600 \\
36600 \\
28800 \\
56000 \\
5900 \\
11400 \\
3200 \\
11700 \\
8500 \\
900 \\
1700\end{array}$ & $\begin{array}{r}27700 \\
41800 \\
44900 \\
22900 \\
43000 \\
6400 \\
22900 \\
2400 \\
7300 \\
6500 \\
1000 \\
3200\end{array}$ & $\begin{array}{r}-37600 \\
11200 \\
8300 \\
-5900 \\
-13000 \\
500 \\
11500 \\
-800 \\
-4400 \\
-2000 \\
100 \\
1500\end{array}$ & $\begin{array}{l}0.022 \\
0.008 \\
0.003 \\
0.008 \\
0.005 \\
0.001 \\
0.098 \\
0.002 \\
0.008 \\
0.001 \\
0.000 \\
0.071\end{array}$ \\
\hline
\end{tabular}


Table 25

Forecasting quality of supply by educational types

\begin{tabular}{|c|c|c|c|c|c|}
\hline Education & Reference forecast & Forecast & Realisation & Forecasting error & Loss \\
\hline Primary Education & 122400 & 122400 & 123600 & 1200 & 0.000 \\
\hline Lower General Secondary Education & 87700 & 90300 & 124300 & 34000 & 0.007 \\
\hline PVE Agriculture & 10100 & 10800 & 20400 & 9600 & 0.016 \\
\hline PVE Construction trades & 19600 & 20800 & 37400 & 16600 & 0.016 \\
\hline PVE Utilities installation & 2700 & 4600 & 4000 & -600 & 0.001 \\
\hline PVE Mechanical trades & 16600 & 18300 & 22000 & 3700 & 0.001 \\
\hline PVE Precision Mechanical trades & 300 & 300 & 100 & -200 & 0.001 \\
\hline PVE Automobile trades & 8800 & 8800 & 11200 & 2400 & 0.003 \\
\hline PVE Electrical trades & 8100 & 8100 & 14200 & 6100 & 0.009 \\
\hline PVE Printing trades & 1700 & 1700 & 0 & -1700 & 0.089 \\
\hline PVE Food trades & 3700 & 4100 & 3900 & -200 & 0.000 \\
\hline PVE Transport and harbour & 8700 & 11200 & 11200 & 0 & 0.000 \\
\hline PVE Others technical & 1500 & 4200 & 3200 & -1000 & 0.001 \\
\hline PVE Administration and Textile and leather trades & 2200 & 2200 & 60500 & 58300 & 1.375 \\
\hline PVE Commerce & 35000 & 35600 & 21400 & -14200 & 0.014 \\
\hline PVE Community care, hotel and catering & 35300 & 36000 & 52000 & 16000 & 0.008 \\
\hline PVE Security & 0 & 3300 & 9800 & 6500 & 0.307 \\
\hline PVE Others & 0 & 400 & 25100 & 24700 & 3.430 \\
\hline Higher General Secondary Education & 130400 & 148900 & 265100 & 116200 & 0.130 \\
\hline IVE Agriculture & 9400 & 21500 & 13700 & -7800 & 0.005 \\
\hline IVE Natural environment & 2400 & 6700 & 5400 & -1300 & 0.003 \\
\hline IVE Technical Laboratory & 6400 & 7400 & 3600 & -3800 & 0.042 \\
\hline IVE Construction technology & 11000 & 25500 & 23000 & -2500 & 0.000 \\
\hline IVE Civil engineering & 2300 & 4700 & 2300 & -2400 & 0.009 \\
\hline IVE Instalation & 1500 & 5500 & 10700 & 5200 & 0.046 \\
\hline IVE Mechanical engineering & 13400 & 29200 & 16400 & -12800 & 0.008 \\
\hline IVE Precision engineering & 1100 & 2100 & 1800 & -300 & 0.001 \\
\hline IVE Automobile technology & 7200 & 16100 & 18600 & 2500 & 0.001 \\
\hline
\end{tabular}




\begin{tabular}{|c|c|c|c|c|c|}
\hline Education & Reference forecast & Forecast & Realisation & Forecasting error & Loss \\
\hline IVE Aircraft technology & 900 & 1000 & 700 & -300 & 0.002 \\
\hline IVE Operational technology & 400 & 1000 & 2700 & 1700 & 0.050 \\
\hline IVE Electrical technology & 17600 & 31500 & 26100 & -5400 & 0.001 \\
\hline IVE Printing technology & 4900 & 8800 & 8200 & -600 & 0.000 \\
\hline IVE Process technologies & 1000 & 3400 & 1900 & -1500 & 0.003 \\
\hline IVE Bakery and catering technology & 1200 & 3100 & 4200 & 1100 & 0.006 \\
\hline IVE Food technology & 1400 & 6600 & 2300 & -4300 & 0.034 \\
\hline IVE Transport and harbour & 3800 & 10900 & 14700 & 3800 & 0.005 \\
\hline IVE Other technology & 0 & 7600 & 300 & -7300 & 0.043 \\
\hline IVE Doctors, dentists and veterinaries assistant & 6400 & 7600 & 7900 & 300 & 0.000 \\
\hline IVE Pharmasists assistant & 5200 & 6400 & 3700 & -2700 & 0.026 \\
\hline IVE Nursing and paramedical services & 5000 & 9400 & 17000 & 7600 & 0.004 \\
\hline IVE Medical laboratory & 300 & 300 & 900 & 600 & 0.010 \\
\hline IVE Social and cultural & 22200 & 25100 & 56900 & 31800 & 0.285 \\
\hline IVE Community care & 22900 & 46800 & 43800 & -3000 & 0.000 \\
\hline IVE hairdressing, Manicures & 4500 & 11400 & 15200 & 3800 & 0.004 \\
\hline IVE Hotel, catering & 8100 & 14500 & 27500 & 13000 & 0.030 \\
\hline IVE Therapeutics and Orthopaedics & 7900 & 9300 & 2900 & -6400 & 0.059 \\
\hline IVE Administration & 34700 & 58600 & 44000 & -14600 & 0.003 \\
\hline IVE Retail & 37500 & 64900 & 71700 & 6800 & 0.001 \\
\hline IVE Secretariat & 12200 & 18300 & 22700 & 4400 & 0.002 \\
\hline IVE Tourism and recreation & 6000 & 10000 & 7300 & -2700 & 0.023 \\
\hline IVE Commerce & 0 & 3300 & 20400 & 17100 & 0.222 \\
\hline IVE Automatisering & 0 & 3900 & 14200 & 10300 & 0.072 \\
\hline IVE Legal and fiscal & 0 & 2600 & 3100 & 500 & 0.000 \\
\hline IVE Assurances & 0 & 1200 & 6400 & 5200 & 0.038 \\
\hline IVE Police, fire and defense & 0 & 10400 & 16200 & 5800 & 0.004 \\
\hline IVE Others & 0 & 1300 & 2200 & 900 & 0.002 \\
\hline HVE Teacher training primary education & 16500 & 17100 & 23500 & 6400 & 0.002 \\
\hline HVE Teacher training languages & 2800 & 3300 & 3300 & 0 & 0.000 \\
\hline
\end{tabular}




\begin{tabular}{|c|c|c|c|c|c|}
\hline Education & Reference forecast & Forecast & Realisation & Forecasting error & Loss \\
\hline HVE Teacher training technology and natural sciences & 2700 & 2700 & 3900 & 1200 & 0.001 \\
\hline HVE Teacher training economics and Sociology & 4100 & 4700 & 3800 & -900 & 0.001 \\
\hline HVE Teacher training physical education & 1800 & 1800 & 2900 & 1100 & 0.002 \\
\hline HVE Teacher training health & 700 & 700 & 800 & 100 & 0.000 \\
\hline HVE Teacher training expression & 5900 & 6100 & 4200 & -1900 & 0.004 \\
\hline HVE Teacher training interpreter and translator & 600 & 600 & 300 & -300 & 0.001 \\
\hline HVE Agriculture and environmental science & 2500 & 2400 & 2200 & -200 & 0.000 \\
\hline HVE Environment sciences & 5100 & 5600 & 5500 & -100 & 0.000 \\
\hline HVE Technical laboratory & 4500 & 6100 & 4500 & -1600 & 0.002 \\
\hline HVE Construction & 3200 & 3700 & 5200 & 1500 & 0.006 \\
\hline HVE Civil engineering & 2400 & 2400 & 3400 & 1000 & 0.003 \\
\hline HVE Mechanical engineering & 8300 & 8300 & 8400 & 100 & 0.000 \\
\hline HVE Electronic & 7600 & 8100 & 6900 & -1200 & 0.001 \\
\hline HVE Information technology & 6800 & 7400 & 10100 & 2700 & 0.005 \\
\hline HVE Chemical technology & 1600 & 1600 & 1100 & -500 & 0.003 \\
\hline HVE Transport and harbour & 900 & 1900 & 3100 & 1200 & 0.003 \\
\hline HVE Nursing and paramedical services & 8700 & 10600 & 10300 & -300 & 0.000 \\
\hline HVE (Physio)therapy & 9200 & 9300 & 9900 & 600 & 0.000 \\
\hline HVE Nutritionist & 1700 & 1700 & 2100 & 400 & 0.009 \\
\hline HVE Radiologist & 400 & 400 & 600 & 200 & 0.001 \\
\hline HVE Other paramedical & 900 & 1300 & 2300 & 1000 & 0.012 \\
\hline HVE Economics & 17700 & 18800 & 15500 & -3300 & 0.003 \\
\hline HVE Commerce & 16400 & 20200 & 22200 & 2000 & 0.002 \\
\hline HVE Tourism and recreation & 3000 & 4000 & 3200 & -800 & 0.007 \\
\hline HVE Legal and fiscal & 0 & 300 & 1800 & 1500 & 0.004 \\
\hline HVE Secretariat & 4300 & 5600 & 3300 & -2300 & 0.005 \\
\hline HVE Business administration & 23900 & 26700 & 32400 & 5700 & 0.008 \\
\hline HVE Communication and journalism & 3800 & 5600 & 9200 & 3600 & 0.048 \\
\hline HVE Social and cultural & 15500 & 15500 & 27600 & 12100 & 0.027 \\
\hline HVE Human resources & 7600 & 8700 & 7900 & -800 & 0.002 \\
\hline
\end{tabular}




\begin{tabular}{|c|c|c|c|c|c|}
\hline Education & Reference forecast & Forecast & Realisation & Forecasting error & Loss \\
\hline HVE Librarian & 1900 & 2700 & 1400 & -1300 & 0.009 \\
\hline HVE Other social and cultural & 300 & 300 & 2700 & 2400 & 0.035 \\
\hline HVE Fine Arts & 10300 & 12700 & 22100 & 9400 & 0.039 \\
\hline HVE Police, fire and defense & 0 & 2200 & 300 & -1900 & 0.038 \\
\hline HVE Others & 4400 & 6400 & 5100 & -1300 & 0.002 \\
\hline UE Literature & 13800 & 15900 & 8000 & -7900 & 0.031 \\
\hline UE Theology & 600 & 600 & 900 & 300 & 0.003 \\
\hline UE Agriculture and environmental science & 3000 & 3500 & 2100 & -1400 & 0.013 \\
\hline UE Mathematics and natural sciences & 13000 & 13800 & 7400 & -6400 & 0.011 \\
\hline UE Construction and civil engineering & 2000 & 2000 & 2700 & 700 & 0.006 \\
\hline UE Civil engineering & 1000 & 1000 & 1100 & 100 & 0.000 \\
\hline UE Mechanical engineering & 3300 & 3300 & 1900 & -1400 & 0.019 \\
\hline UE Electrical engineering and inform. tech. & 1800 & 1800 & 700 & -1100 & 0.014 \\
\hline UE Information science & 3000 & 3000 & 1600 & -1400 & 0.033 \\
\hline UE Veterinary and medical sci. & 6600 & 6600 & 4100 & -2500 & 0.003 \\
\hline UE Dentist & 400 & 400 & 400 & 0 & 0.000 \\
\hline UE Pharmacy & 1100 & 1100 & 2000 & 900 & 0.010 \\
\hline UE Econom-ics (-etry) & 15300 & 16700 & 11200 & -5500 & 0.017 \\
\hline UE Business administration & 5500 & 6300 & 11200 & 4900 & 0.054 \\
\hline UE Accounting & 0 & 900 & 5200 & 4300 & 0.055 \\
\hline UE Law \& Management & 19000 & 19000 & 15400 & -3600 & 0.004 \\
\hline UE Social sciences & 22800 & 26700 & 19600 & -7100 & 0.007 \\
\hline UE Other socio-cultural & 0 & 0 & 700 & 700 & 0.003 \\
\hline UE Fine Arts & 2100 & 2100 & 1000 & -1100 & 0.049 \\
\hline UE Other & 2400 & 2400 & 1300 & -1100 & 0.007 \\
\hline
\end{tabular}

